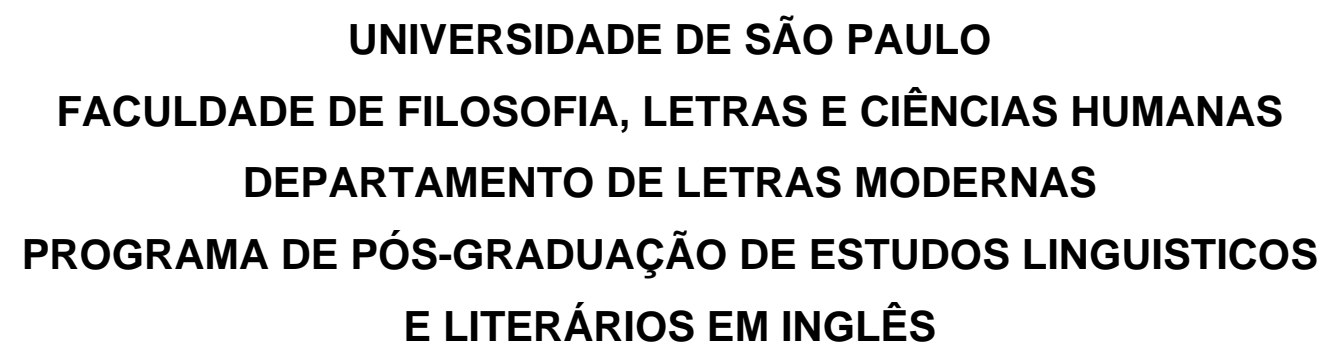

\title{
TEIAS DE SIGNIFICAÇÃO \\ PERFORMANCE DE LÍNGUA-FRANCA E \\ NARRATIVAS VIVENCIADAS DE IDENTIDADE
}

São Paulo 
UNIVERSIDADE DE SÃO PAULO

FACULDADE DE FILOSOFIA, LETRAS E CIÊNCIAS HUMANAS DEPARTAMENTO DE LETRAS MODERNAS PROGRAMA DE PÓS-GRADUAÇÃO DE ESTUDOS LINGUISTICOS E LITERÁRIOS EM INGLÊS

\title{
TEIAS DE SIGNIFICAÇÃO \\ PERFORMANCE DE LÍNGUA-FRANCA E NARRATIVAS VIVENCIADAS DE IDENTIDADE
}

\author{
IRENE SINNECKER LEVIN
}

Dissertação apresentada ao Programa de Pós-Graduação em Estudos Lingüísticos e Literários em Inglês do Departamento de Letras Modernas da Faculdade de Filosofia, Letras e Ciências Humanas da Universidade de São Paulo, para a obtenção do título de Mestre em Letras.

Orientador: PROF. DR. LYNN MARIO TRINDADE MENEZES DE SOUZA

São Paulo 


\section{BANCA EXAMINADORA}

Prof. Dr. Lynn Mario Trindade Menezes de Souza - FFLCH-USP - Presidente

Prof. ${ }^{a}$ Dr. ${ }^{\text {a }}$ Katia Rubio - EEFE-USP - Titular

Prof. ${ }^{a}$ Dr. ${ }^{\text {a }}$ Walkyria Maria Monte Mór - FFLCH-USP- Titular

Parecer da Comissão Julgadora: O trabalho trata de um tema relevante no contexto da sociedade contemporânea, e dá um tratamento criativo e inovador à investigação. 
Aos queridos Gabriel e Thomas, sou infinitamente grata pelo amor e pela compreensão diante do tempo que esta dissertação tomou à nossa convivência. 
Sou infinitamente grata a Deus pela revelação da vida eterna através de Cristo!

Agradeço ao Prof. Dr. Lynn Mario Trindade Menezes de Souza pelos vários insights, pela extrema sensibilidade e pelo respeito à diferença que esta orientação exigiu e exige ao longo do caminho.

Às Profas. Dras. Walkyria Monte Mór e Kátia Rubio, agradeço o carinho, o respeito e as incomparáveis contribuições.

Ao José Eduardo Heflinger Jr. pela ternura com que cedeu sua pesquisa e esteve sempre à disposição.

Agradeço as inúmeras possibilidades de aprendizado com Cláudio Roberto Melchert, Laura Beatriz Penteado de Sá Melchert, Maria Helena Leone Heflinger Renato Martins Figueiredo, Célio Mauro Placer Rodrigues de Almeida, Alcinéia Emmerick de Almeida, Paulo Roberto Borsato, Renato Pinto de Oliveira, Marcello Bulgarelli, Sandra Helena Correia Monteiro, Edite dos Santos Nascimento Mendez Pi, Márcia Cristina Arruda de Araújo, Marie Wing, Walter Thomas Sinnecker, Shing-Mei Sinnecker, Alexander Sinnecker, Vera de Oliveira Sinnecker, Nahum Hertzel Levin e com os meus queridos alunos e alunas. 


\section{Resumo:}

Esta pesquisa de cunho etnográfico procura investigar o complexo da linguagem, focalizando o caráter performativo da linguagem e a busca por uma língua-franca, de modo geral, e o papel do modo narrativo, em particular, na construção de identidade, considerando-se que esta é composta por um complexo de vivências de corpo, alma e espírito, sócio-históricas e culturais contextualizadas. Os significados de nossas construções narrativas são constituídos por e constituem nossos contextos sociais, culturais e ideológicos. Identidade não é homogenia, estável ou fixa, pelo contrário, trata-se de uma construção híbrida, uma teia de significação performativa (Geertz 1973; Hall 1996, 1997, 2003; Bhabha 1990, 1994, 1998, 2000; Menezes de Souza 2004, 2006); é um complexo, conjunto de narrativas, de processos de ação, de construção de significação, que formam o sujeito (Bruner, J. 1986, 1992, 2001; Klapproth 2004). A vivência contextualizada é o elemento de ligação entre narrativa e identidade (Merleau Ponty 1945, 1961, 1984; Varella 1991, Lakoff \& Johnson 1999, Bakhtin 1988, Lemke 1997). Procuraremos demonstrar como as narrativas construídas em torno da comunidade cafeeira no Brasil do século XIX, especialmente em torno da imigração de cunho particular, para a fazenda de café Ibicaba do Senador Vergueiro, no estado de São Paulo, são vivências de identidades contextualizadas, que repercutem na construção de outras identidades que exercitam o direito de narrar e de significar até os dias de hoje. Para sobrevivermos à crise de identidade criamos várias identificações. Através do direito de narrar sob perspectivas, vivências e contextos distintos, sejam de inclusão ou deslocamento, sejam voltadas para o passado ou futuro, somos todos híbridos ao lidarmos com a indeterminação e com a contingência de identidade, que é o que temos em comum. Detectamos que várias "verdades" são construídas sócio-histórica e culturalmente a partir de seus contextos e que 'as identidades são um complexo de narrativas vivenciadas, formadas nas zonas híbridas de encontro de culturas' (Bhabha 1994).

Palavras-Chave: linguagem, performance, narrativa, vivência, identidade. 


\section{Abstract:}

The present ethnographic research aims at investigating the complex of language, focusing on the performative character of language and the search for a lingua-franca as general aspects, as well as the role of the narrative mode as a particular aspect in the construction of identity, considering that it is composed by a complex of living experiences of body, soul and spirit, contextualized socio-historically and culturally. The meanings of our narrative constructions are constituted by and constitute our social, cultural and ideological contexts. Identity is not homogeneous, stable or fixed, much the opposite, it is a hybrid construction, a web of performative significance (Geertz 1973; Hall 1996, 1997, 2003; Bhabha 1990, 1994, 1998, 2000; Menezes de Souza 2004, 2006), it is a complex of narratives, processes of action of meaning making that form the subject (Bruner, J. 1986, 1992, 2001; Klapproth 2004). The contextualized embodiment and living experience is the element of connection between narrative and identity (Merleau Ponty 1945, 1961, 1984; Varella 1991, Lakoff \& Johnson 1999, Bakhtin 1988, Lemke 1997). We aim at demonstrating that the narratives constructed around the coffee community in Brazil in the XIX century, especially around the immigration of private initiative to Ibicaba coffee farm owned by Senator Vergueiro in the state of São Paulo, are living experiences of contextualized identities that have repercussions on the construction of other identities which exercise the right to narrate and signify to date. In order to be able to survive the crisis of identity we create various identifications. Through the right to narrate under distinct perspectives, living experiences and contexts, rather inclusive or dislocated, looking to the past or the future, we are all hybrid in dealing with the indeterminacy and contingency of identity which is common to us all. We have detected that various "truths" are socio-historically and culturally constructed from their respective contexts and that identities are a complex of narratives of living experiences formed in the hybrid zones in which different cultures encounter (Bhabha 1994).

Key-words: language, performance, narrative, living experience, identity. 


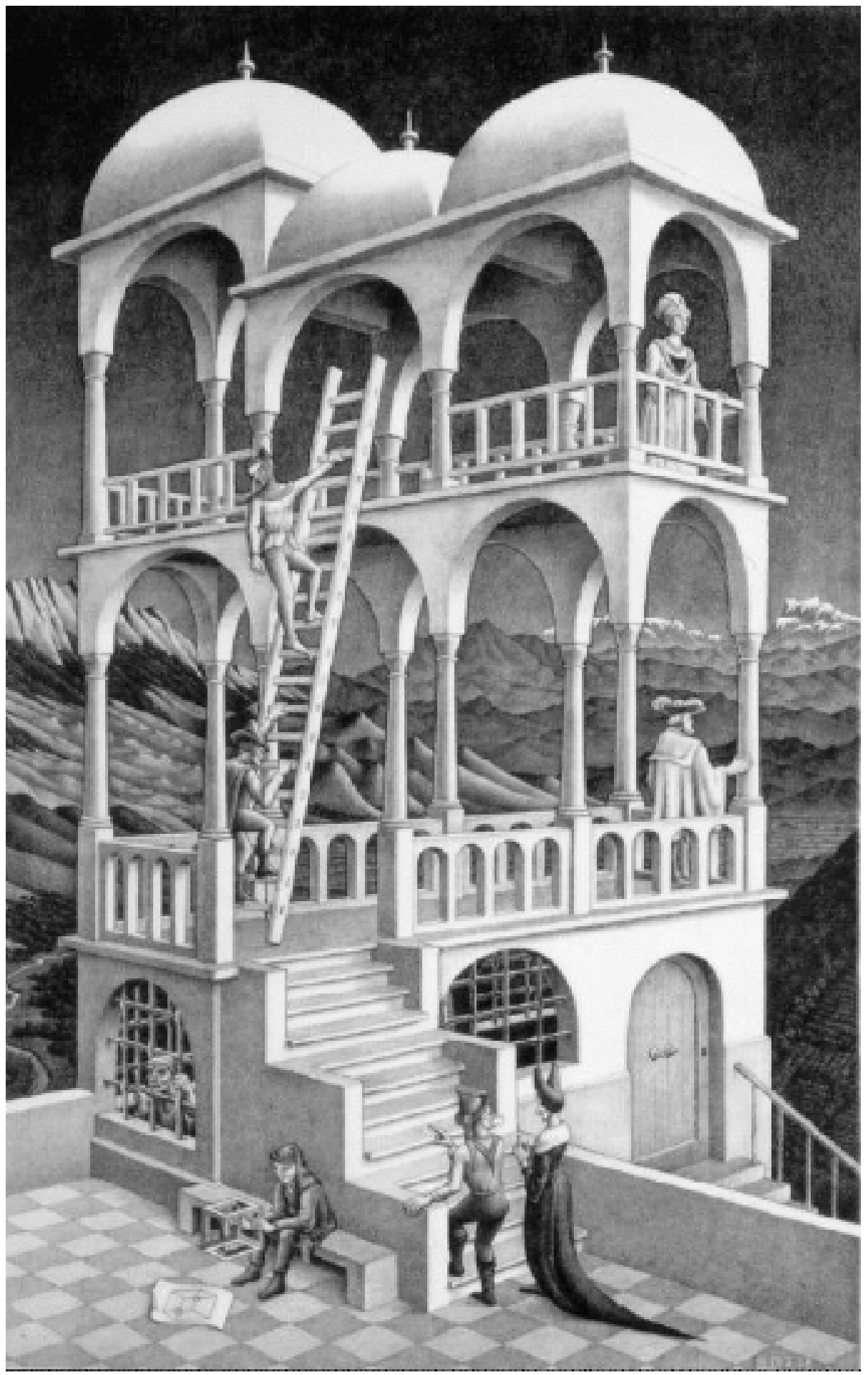

\section{TEIAS DE SIGNIFICAÇÃO PERFORMANCE DE LÍNGUA-FRANCA E NARRATIVAS VIVENCIADAS DE IDENTIDADE}


Imagem: Escher 1958 "Belveder" litografia

A imagem de capa é uma construção perpretada pelo magnífico Escher, tratase de uma ilusão de ótica, pois, se acompanharmos, cautelosamente, as colunas que sustentam sua estrutura, verificaremos que suas disposições não são possíveis e que, conseqüentemente, tal construção jamais poderia existir tridimensionalmente; no entanto, somos capazes de visualizá-la e dificilmente percebemos sua problemática inverossímil, uma vez que já estamos condicionados a tomar como realidade certos padrões de estrutura. Da mesma forma, ao darmos asas às nossas construções narrativas vivenciadas de identidade, consideramos que elas são uma realidade estável e não passível de sofrer interpretações diversas, de acordo com os respectivos narravintes com os quais possamos vir a interagir. Esquecemos o quão intricados estamos em nossos processos construtivos a ponto de esquecermos que a vivência é tão mutante quanto a própria vida. 


\section{ÍNDICE}

1. INTRODUÇÃO__ 1

1.1 Por que Narrativas Vivenciadas da Identidade?___ 1

1.2 A Pesquisa e suas Inquietações___ 5

$\begin{array}{lll}1.3 & \text { A Comunidade Pesquisada___ }\end{array}$

$\begin{array}{lll}1.4 & \text { Organização da Dissertação____ } & 14\end{array}$

2. ALGUMAS INQUIETAÇÕES TEÓRICAS_ 16

2.1 A Performatividade da Linguagem___ 17

2.2 A Busca pela Língua- Franca___ 19

2.3 O Complexo da Linguagem___ 21

2.4 A Mente Corporificada: 24

2.4.a) As Conclusões das Ciências Cognitivas____ 26

2.4.b) O Corpomídia___ 30

2.4.c) O Sujeito da Linguagem: Corpo, Alma e Espírito____ 31

2.5 Vivências Contextualizadas___ 33

2.6 Narrativas como Construção de Significação: ___ 36

2.6.a) Pensamento Lógico-científico e Pensamento Narrativo_ 36

2.6.b) Narrativa como Processo de Ação Social e Cultural___ 38

2.6.c) Narrativas Reais e Narrativas Imaginadas____ 41

2.6.d) Narrativa como Busca Existencial e o Direito de Narrar__ 43

2.7 Identidade como Teia de Significação: ___ 46

2.7.a) A Crise de Identidade e o Processo de Identificação___ $\quad 47$ 
2.7.b) A Construção de Identidades Nacionais

2.7.c) Identidades Híbridas___ 51

2.7.d) Identidade do Imigrante___ 53

3. VIVÊNCIAS DA COMUNIDADE PESQUISADA__ 56

3.1 Vivência da Narrativa Nacionalista de Inclusão e Pertencimento_ 57

3.2 Narrativa do Imigrante enquanto Incômodo e Deslocamento___ 67

3.3 Identidade Progressista do Imigrante___ 85

3.4 Identidades Híbridas nas Raízes do Passado___ 90

3.5 Vivenciando o Hibridismo Aqui e Agora____ 95

3.6 Conquistando o Direito de Narrar___ 99

3.7 Reconstruindo Identidades em Comunidades de Prática___ 102

4. INQUIETAÇÕES FINAIS___ 123

5. BIBLIOGRAFIA__ 136

6. FONTES DE FOTOS__ 145

7. PERFORMANCE: "The Book Is On The Table" 146

e-mail para contato: irene.sinnecker@ig.com.br revisão: Marcello Bulgarelli (bulgarel@uol.com.br) 


\section{TEIAS DE SIGNIFICAÇÃO}

\section{Performance de Língua Franca e Narrativas Vivenciadas de Identidade.}

"Sentimos que, mesmo quando todas as questões científicas
possíveis tenham sido respondidas, os problemas da vida
permanecem completamente intocados.

(Wittgenstein 1961:73 apud Van Lier 1989:36, tradução nossa)

\section{INTRODUÇÃO}

\subsection{Por que Narrativas Vivenciadas de Identidade?}

Trago impressos no meu ser elementos genéticos alemães e chineses; na família trago elementos judaicos, franceses, ingleses, russos e brasileiros. Certamente, relações interculturais e híbridas sempre estiveram presentes no meu dia-a-dia. Interesso-me pelas formas de identidade cultural que são criadas nas zonas limítrofes, as quais Bhabha (1994) descreve como intersecções e sobreposições entre as esferas de classe, gênero, raça, nação, geração e localidade. Concordo com Heidegger, quando nos explica que os gregos reconheceram a fronteira não como o local onde algo termina, mas onde algo inicia sua presença.

Ao partir da China, com minha família, aos dois anos de idade, fugidos dos sofrimentos impingidos pelo comunismo, chegamos ao Brasil, em 1961, com uma coleção de narrativas que faziam parte da identidade que estava sendo deixada pra trás: sobre a casa do avô paterno alemão, na concessão internacional de Shangai, que era governada pelos ingleses; sobre a avó materna chinesa, professora de inglês, cujo esposo - meu avô materno chinês - teve a farmácia de ervas de sua família queimada pelos japoneses; sobre o hospital onde minha mãe era chefe das enfermeiras; sobre o parque onde eu ia passear de riquixá todos os dias com minha ama-de-leite e com minha avó paterna chinesa; sobre meu pai, que deixava para trás o país onde nascera, o colégio inglês onde estudara, um país que lhe era hostil, pois não era considerado chinês, nem alemão. Durante os 45 dias em que navegamos a 
bordo do "Boissevain" para aqui chegar, permaneceu, no ar e na imensidão do mar, aquele sentimento de identidade suspensa, inclusive na certidão expedida pela policia militar que atesta nossa chegada, está escrita, em maiúscula, a palavra Apátrida. Vínhamos pelo sonho da liberdade e do bem-estar que o comunismo não nos proporcionava, quem éramos e quem seríamos afinal? Chegamos a um país totalmente diferente, cuja língua não compreendíamos; apesar da pouca idade, as narrativas que, até hoje, persistem na família deixaram marcas profundas na minha formação de identidade, narrativas do passado abandonado, do conflito que vivenciamos na chegada - gostava de brincar na rua com as crianças, pois tinha a ilusão de ser igual a elas, mas, quando voltava pra casa, tinha de ser chinesa - e do futuro incerto. Ainda, ironicamente, fui naturalizada brasileira aos quinze anos e a validade da naturalização expirava aos vinte e um, mas só foi descoberta pela burocracia e por mim aos trinta e cinco, quando começou outra jornada para tentar obter alguma nacionalidade. Durante dois anos permaneci novamente apátrida, entre discordâncias burocráticas dos governos alemão, chinês e brasileiro, persistindo um sentimento estranho de não pertencer; no entanto, não definir a identidade trazia uma sensação de alívio, de liberdade. Trazia, também, uma infinidade de dificuldades de ordem burocrática e prática e, embora tenha conseguido naturalizar-me brasileira novamente, apelando ao Ministro da Justiça, ainda me pergunto "quem sou?", "quem somos?", será que basta narrar nossa vivência?"

Tanto a pós-modernidade, como condição socioeconômica, quanto o pósmodernismo, como expressão cultural (Usher \& Edwards 1994) permeiam nosso processo de formação de discurso e de identidade, nossa vivência do momento pós-moderno (pós-colonial, pós-feminista, pós-estruturalista...) no qual o paradoxo e a multiplicidade de significados e de escolhas negam a eficácia da cientificidade modernista e criam novos caminhos para a organização do saber.

Trilho um caminho com o ensino e o aprendizado de língua inglesa; especializei-me em aulas particulares, sem qualquer tipo de discriminação quanto a idade, gênero, raça, credo, profissão, personalidade ou 
comportamento; particularmente, estou interessada nos processos de formações discursivas híbridas e polissêmicas que constituem cada indivíduo no seu confronto com o social, na diversidade e na riqueza cultural que todos e cada um de nós - representamos enquanto interlocutores, na manifestação desses elementos enquanto significação para o indivíduo na relação reflexiva e interativa com o todo. Diante de tais elementos, aprender a se expressar em uma determinada língua significa aproximar-se de uma nova cultura, de outras metáforas, por vezes de outra ontologia, do aprender a conhecer, a vivenciar, a traduzir, a interpretar e a verbalizar o ser e o existir.

No atual momento histórico, social, político e econômico em que vivemos, a Língua Inglesa ocupa uma posição hegemônica na qual está sobrecarregada do mito de língua-franca. Em um país em desenvolvimento, como o Brasil, em uma cidade cosmopolita, como São Paulo, tal mito toma proporções descabidas. Os alunos aproximam-se dos professores declarando que querem e que precisam falar Inglês, como se, em um passe de mágica, toda a questão da contingência de suas identidades pudesse ser resolvida instantaneamente. Impera a ilusão de que uma simples língua - no momento a Língua Inglesa possa resolver toda uma problemática relativa ao papel da linguagem na comunicação.

Após ter participado de uma pesquisa etnográfica conduzida por quatro pesquisadoras em um curso de poesia de graduação em Língua Inglesa ${ }^{1}$, detectamos uma série de dificuldades e de deficiências dos alunos na sua expressão, questões estas que poderiam ser resumidas na falta de envolvimento dos participantes no processo de comunicação, devido à dificuldade que temos de perceber o outro, de respeitarmos sua diferença e sua significação, de negociarmos com elas, em um processo comum de construção de sentidos, de identidade.

1. Festino, C. G. 2001 "Ethnographic Research carried out in a College Course on English Poetry" , USP-FFLCH, unpublished Monteiro, S.H.C. 2001 "A Sala de Aula Universitária e o Poder: uma Experiência com a Etnografia da Fala", 50 GEL-USP 2002

Scolfaro, C. J. 2001 "Because we are all equal, we have the right to be different" : um relato etnográfico, USP-FFLCH, não-publicado

Sinnecker Levin, I. 2001 "A Arte de Camalear : Negociando com a Diferença e a Significação na Sala de Aula", 50 GEL-USP 2002 
As questões de identidade estão presentes no que vivenciamos ou verbalizamos com a linguagem: quem sou? qual o significado da minha/nossa vida? por quê? como? para quê? de que é feito? questões para as quais tanto a filosofia quanto a epistemologia, a arte e a religião vêem construindo respostas e oferecendo uma diversidade de caminhos que podem ser trilhados.

Trilho outro caminho de conhecimento, através da performance e da dança, e o que me atrai, nessa relação, é a linguagem corporal, a possibilidade de dizer sem falar nem escrever, a comunicação não-verbal, a anatomia funcional e psico-comportamental, a memória muscular vivencial experimentada pelo corpo como texto, a leitura desse texto e de seus subtextos. A manifestação dessa narrativa e de sua contribuição na formação do discurso comunicativo enquanto experiência vivida, essencialmente ontológica e concomitantemente muscular, oral, etc. Uma performance corporal pode ser a mesma em qualquer parte do mundo - passa a ilusão de estar mais acessível e disponível que a confusão das línguas; no entanto, ou o corpo encontra-se abandonado pelos próprios indivíduos, ou interpelado por interesses múltiplos que são o próprio reflexo da condição pós-moderna. A tentativa de recuperá-lo, enquanto elemento ativo no processo discursivo, implica no processo de agência do sujeito: nosso corpo em ação leva a formulações e gesta a comunicação com o mundo (Martins 2002).

Ao ser convidada para prestar consultoria em Língua Inglesa, para a Sociedade Pró-Memória de Limeira, para a Secretaria da Cultura Turismo e Eventos de Limeira e, posteriormente, ao Projeto Imigração Resgate, pelo pesquisador - e meu amigo pessoal há 30 anos - José Eduardo Heflinger Jr., não imaginava que, ao vivenciar esses projetos, estaria participando de uma pesquisa etnográfica que viria a se tornar uma dissertação de mestrado com base em suas pesquisas. O caminho trilhado por Limeira em busca de sua história e de sua identidade nacional é cruzado por narrativas da ação de imigrantes que, aqui, chegaram para contribuir na construção do nosso país, da nossa identidade. 


\title{
1.2. A Pesquisa e suas Inquietações
}

\begin{abstract}
"Um bom etnógrafo nunca alegará ter encontrado evidências suficientes ou, até mesmo, adequadas para o conhecimento a respeito das pessoas estudadas. Um modo crucial no qual a etnografia difere da pesquisa normativa é que, se for feita corretamente, ela ativamente encoraja a participação de professores e de aprendizes."
\end{abstract}

(Van Lier 1989:47, tradução nossa)

Esta pesquisa procura investigar o caráter performativo da linguagem, a busca por uma língua-franca de modo geral e, também, o papel do modo narrativo em particular, na construção de identidade, considerando-se que esta é composta por um complexo de vivências sócio-históricas e culturais contextualizadas.

O projeto se justifica pelo tratamento histórico que é dado:

- à linguagem como sendo abstrata, homogênea, transparente, representativa de uma realidade universal;

. às narrativas que são reduzidas a um gênero, ao discurso da lingüística, à ficção da teoria literária ou, ainda, a relatos populares sem importância;

- às identidades como sendo essencialistas, estáveis, imutáveis, através das vicissitudes da história, fruto de um processo racional destituído de vivências que experimentamos de corpo, alma e espírito.

Os significados de nossas construções narrativas são constituídos por e constituem nossos contextos sociais, culturais e ideológicos; quando pessoas comuns narram suas histórias/estórias evidenciam as questões de identidade na sua performance emergente, exercendo o direito de narrar. Identidade não é homogênea, estável nem fixa, pelo contrário, trata-se de uma construção híbrida, uma teia de significação performativa (Hall 1996, 1997, 2003; Bhabha 1990, 1994, 1998, 2000; Menezes de Souza 2004, 2006), é um complexo, conjunto de narrativas, de processos de ação, de construção de significados que formam o sujeito (Bruner, J. 1986, 1992, 2001; Klapproth 2004). A vivência ${ }^{2}$ contextualizada é o elemento de ligação entre narrativa e identidade

2. Termo utilizado aqui não apenas no sentido marxista de experiência social vivida, mas, de acordo com a trialética de Soja (1996), enquanto um complexo formado pelo social vivido, o histórico concebido e o espaço contextual percebido. 
(Merleau Ponty 1945, 1961, 1984; Varella 1991, Lakoff \& Johnson 1999, Bakhtin 1988, Lemke 1997).

Seguindo as proposições de Hall (1997), ao classificar o sujeito como do lluminismo, sociológico e pós-moderno, poderíamos imaginar que apenas o sujeito pós-moderno seria contingente, performativo, plural, móvel, múltiplo, contraditório, formado e transformado pelas representações e pelas interpelações de sistemas sócio-culturais. Procuraremos demonstrar como as narrativas construídas em torno da comunidade cafeeira no Brasil do século XIX, especialmente em torno da imigração de cunho particular, principalmente de alemães e, também, de suíços, para a fazenda de café lbicaba, do Senador Vergueiro, no estado de São Paulo, são vivências da identidade contextualizadas que repercutem na construção de outras narrativas, de outras identidades, até os dias de hoje, e que, independente do momento histórico em que estas se inserem, os sujeitos já eram "pós-modernos" dependendo de seus loci de enunciação, ou híbridos conforme Bhabha (1994), formados nas lacunas da ambigüidade existente entre significante e significado.

Discutiremos a inquietação: 'as identidades são um complexo de narrativas vivenciadas, formadas nas zonas híbridas (Bhabha 1994) de encontro de culturas', através da análise de documentos narrativos escritos, depoimentos narrativos orais, textos e contextos da construção de identidades relativas à comunidade em torno da imigração particular, promovida na fazenda de café Ibicaba, do Estado de São Paulo, no Brasil do século XIX, e sua repercussão na construção de identidades individuais e nacionais até os dias de hoje.

O trabalho será desenvolvido sob uma perspectiva interpretativista discursiva, através da análise contextualizada e de cruzamento de dados, inclusive devido às várias gerações apresentadas, no material analisado. Indicaremos como, no encontro de culturas, ao entrar em espaços novos, os diálogos são pontes, visões de mundo, expectativas, conflitos onde as identidades em torno daquela comunidade são construídas e interpretadas em teias de significação (Geertz 1973), contextual em fluxo. 


\begin{abstract}
"Acreditando, com Max Weber, que o homem é um animal suspenso em teias de significação que ele mesmo teceu, eu considero a cultura como essas teias e a sua análise não como sendo uma ciência experimental em busca de normas, mas uma ciência interpretativa em busca de significado."
\end{abstract}

(Geertz 1973:5, tradução nossa)

Esta é uma pesquisa qualitativa, de cunho etnográfico, sendo que a etnografia é vista como a arte de camalear. Camalear, aqui, significa ser maleável, assumir diferentes papéis, posicionamentos, pontos de vista. Colocar-se na posição do outro, compreender sua diferença, respeitar sua casta, sua história, sua cultura. Dar lugar para a subjetividade de o outro sobreviver e existir. Interpretar e traduzir o sentido de significados, considerando perspectivas múltiplas. Exercer o olhar crítico numa relação de espelho, em que ele se volta pra nós mesmos. Embarcar numa crise de identidade construtiva. Mesclar cores a caminho do aprendizado. Tentar compreender significados locais que se refletem no eu. Negociar a construção do real numa relação dialógica.

Refiro-me a uma meta-etnografia, uma situação na qual o etnógrafo se aproxima de uma comunidade para tentar identificar comportamentos, significados referentes a ela, mas, por fazer parte dela, inclusive representando os diferentes papeis pesquisados, passa a reavaliar o sentido do eu e do outro a partir dessa interação. Toda experiência é dinâmica, transforma o eu, mas 0 modo de compreendê-la faz toda a diferença em relação ao que levamos dela. O grau de envolvimento/motivação dos interlocutores define a troca. Pensamos, criamos e negociamos com a língua o tempo todo. A comunicação é um enunciado completo, contextualizado, holístico. Verbalizamos a necessidade de lidarmos com nossos conflitos e com nossos paradoxos.

\title{
1.3. A Comunidade Pesquisada
}

A comunidade escolhida é representativa de um importante período histórico brasileiro, que interferiu na formação do conceito de identidade da nação, por ser o início da imigração de cunho particular e, conseqüentemente, de uma parte da 
miscigenação. Detectamos um complexo de identidades vivenciadas que se formaram em torno dos conflitos sócio-culturais, pelo fato da Fazenda Ibicaba ser, na época, foco da transição econômica e social, para onde diversas correntes político-sociais convergiam. A Fazenda Ibicaba, atualmente, faz parte dos "Roteiros Turísticos" das fazendas históricas da região de Limeira, trata-se de um circuito de visitação que atrai turistas, alunos, pesquisadores e historiadores. Pelo fato de prestarmos consultoria à Sociedade Pró-Memória de Limeira, à Secretaria de Cultura e Eventos de Limeira e ao Projeto Imigração Resgate que, há muitos anos, desenvolvem pesquisas em torno da comunidade, tivemos acesso à farta documentação a partir de diferentes posições e perspectivas.

Introduziremos a comunidade com uma breve contextualização: o Senador Nicolau de Campos Vergueiro foi o primeiro fazendeiro, em todo Brasil, a receber e a financiar a vinda de portugueses, alemães e suíços, como meeiros em sua cultura de café na fazenda Ibicaba, situada na Vila de Limeira (Cordeirópolis-SP) a partir de 1840. Como líder da Casa Vergueiro, muitas críticas foram emitidas contra essa personagem; no entanto, ele leva a glória de ter promovido esse movimento que colheu técnicas e conhecimentos dos indiscutíveis heróis que contribuíram para a formação do conceito de nação que envolve o povo brasileiro.

No Sul do Brasil, os colonos recebiam status de pequenos proprietários rurais, pois entravam imediatamente na posse da terra, mas, em São Paulo, houve importação de braço para substituir o escravo e o sistema que se adotou foi o de parceria, pagava-se o trabalho do colono com uma porcentagem sobre a colheita, o que gerou algumas agitações políticas. Em 1846, foi fundada, no complexo Ibicaba, a Colônia Vergueiro, que trouxe imigrantes mediante assinatura de um contrato e, posteriormente, forneceu imigrantes para todos os proprietários que se interessavam pelo projeto, ampliando os negócios após a abolição do tráfico de escravos em 1850. Em retrospecto, analisaremos as construções de identidade dos seguintes membros, em torno dos acontecimentos do século XIX e sua repercussão até os dias de hoje: 
- A Casa Vergueiro representada aqui pelo Senador Vergueiro e por seu filho Comendador José Vergueiro, principais responsáveis pelas colônias de parcerias implantadas a partir de 1846;

- Thomas Davatz, mestre-escola suíço que chegou em 1855, encarregado de fazer um relatório sobre a situação brasileira para os governos europeus. Ao perceber que viera pelo sonho de uma vida melhor, mas nunca passaria de proletário rural, liderou, em 1856, a rebelião de colonos mais grave da época, que teve como conseqüência a proibição da imigração para o Brasil pelo governo prussiano em1859.

- A Família Levy, de origem judaica, cujos membros saíram da região do Reno na Alemanha, em 1857, para se tornarem colonos de Vergueiro no Brasil e passaram, posteriormente, a proprietários da fazenda Ibicaba. Dela faz parte Paulo Masuti Levy, empresário do ramo da construção à frente da Engepe, presidente da Sociedade Pró-Memória de Limeira e grande mentor do Projeto Imigração Resgate.

- O Comendador José Vergueiro, filho do senador, adotou Catharina Vergueiro, nascida em 1852, no norte da Alemanha, filha de Catharina Drenkhan, uma pobre imigrante mãe-solteira que veio para o Brasil, movida pelo "sonho de felicidade", mas faleceu após sua chegada ao porto de Santos. Catharina Vergueiro casou-se com o alemão Detlef Brune, administrador da fazenda, e teve com ele nove filhos. Detlef retornou com os filhos para a Alemanha após a morte de sua esposa em 1887, mas a filha mais velha Carlota Schmidt, nascida em Ibicaba, em 1875, escreveu suas memórias sobre a fazenda.

- A neta mais velha de Carlota Schmidt, a Doutora Lotte Köhler, médica psicanalista de 82 anos de idade, até a presente data (2007) residente em Munique. 
- O pesquisador José Eduardo Heflinger Jr., conhecido por todos como Toco, editor da revista Povo em Limeira, diretor da Sociedade PróMemória de Limeira, ex-secretário adjunto de Cultura, Turismo e Eventos de Limeira, idealizador do Projeto Imigração Resgate e a construção das identidades limeirense e nacional em repercussão à sua pesquisa.

Os documentos e depoimentos representativos da comunidade analisada foram escolhidos por apresentarem uma teia de interpretações de fatos vividos pelos membros pertencentes a ela, que nos permitiu detectar que vários significados são construídos socio-culturalmente a partir de diferentes loci de enunciação e períodos históricos, inclusive influenciando esta e outras pesquisas. Os dados consistem de seleções e de compilações de narrativas a partir dos seguintes documentos escritos e depoimentos orais:

- Documento Escrito DE-1 - Caderno de Memórias n¹- O Senador Vergueiro e a Imigração Européia, publicação da Sociedade Pró Memória de Limeira, pelos editores José Eduardo Heflinger Junior e Paulo Masuti Levy, em Limeira, Setembro de 1999, com o apoio cultural da Prefeitura Municipal de Limeira, da Secretaria Municipal da Cultura, Turismo e Eventos, do Papel Chamois e da Ripasa. Trata-se de um resumo biográfico do Senador Vergueiro a partir de seus três maiores historiadores - Reynaldo Kuntz Busch, Djalma Forjaz e José Sebastião Witter - e da observação da importância de suas experiências pioneiras com imigração desenvolvidas na Fazenda Ibicaba, como principal fato histórico da origem da cidade de Limeira. Para os editores, "quase tudo foi escrito sobre o Senador, mas muito há ainda para ser pesquisado sobre a experiência de colonização, com a imigração de europeus para o Brasil". A publicação traz uma série de anexos com a relação das primeiras 82 famílias que participaram da fundação da "Colônia Senador Vergueiro", em 1 de Agosto de 1846. Tais gerações foram precursoras do movimento industrial e trouxeram, consigo, o braço técnico que veio formar o alicerce para a instalação das primeiras oficinas, marcenarias e outras atividades especializadas em artes, ainda não desenvolvidas no país. A publicação 
comenta que, apesar dos conflitos trabalhistas entre fazendeiros e colonos imigrantes, os livros de registros da fazenda mostram que a grande maioria saiu da fazenda com posses. Sobre a carta do Anexo VII, de um imigrante que enaltece o empreendimento, comentam: "resta saber se a mesma é autêntica e com que intenções foi escrita. São muitas as questões em aberto para futuras pesquisas". Os editores agradecem o interesse do prefeito Pedro Theodoro Kühl, descendente de imigrantes de Ibicaba, pelo resgate da história documental.

- Documento Escrito DE-2 - Memórias de um Colono no Brasil (1850), livro escrito por Thomas Davatz reeditado após trinta anos pela Livraria Martins Editora e pela Editora da Universidade de São Paulo, como parte da Biblioteca Histórica Brasileira, no ano do Sesquicentenário da Independência do Brasil, em São Paulo, 1972, com tradução, prefácio e notas de Sérgio Buarque de Holanda. A editora da USP não participa de reedições, mas considerou esse volume, que estava esgotado, indispensável ao estudo de nossa história. O autor narra sua versão sobre as condições brasileiras, o tratamento dado aos colonos e a sublevação. Declara que seus objetivos são amparar os colonos, acalmar a febre de emigrar e esclarecer que há pouco lucro financeiro.

- Documento Escrito DE-3 - Família Levy - livreto comemorativo dos 140 anos da família no Brasil, publicado em 1997. Contém registro da história da família, fotografias e genealogia, os quais celebram o sucesso da atual numerosa família que veio pra ficar. Declaram celebrar o futuro, envolvidos em imagens e em memórias que reverenciam a origem da família no Brasil, que, de colonos que carpiam e colhiam em Ibicaba, conseguiram, no espaço de quinze anos, saldar dívidas com o Senador Vergueiro e guardar capital para abrir seu próprio negócio na cidade de Limeira. Em 1890, passaram a donos da fazenda Ibicaba e concretizaram o sonho de abraçar a terra que os recebera, tecendo uma teia de realizações nas cidades de Limeira, Cordeirópolis, Pirassununga e 
Santos. Segundo o casal Maria Silvia Levy e Paulo Masuti Levy, "cada um de nós, embora com um passado comum, temos, no presente, um formato, um rosto, uma história. Que possamos continuar a elaborar o presente, para que se torne passado e alimente com sua seiva as gerações que se seguirem".

- Documento Escrito DE-4 - Recordações de Infância de Carlota Schmidt no Ibicaba, livro organizado por José Eduardo Heflinger Jr., Paulo Masuti Levy e Rommel Siqueira Campos Cantalice, edição bilíngüe português-alemão, com fotos de época, publicada com o apoio da Secretaria Municipal de Cultura de Limeira, da Prefeitura Municipal de Cordeirópolis, dos Consulados da Alemanha e da Suíça no Brasil, do Instituto Histórico e Geográfico de São Paulo, do Johan Jacobs Museum em Zurique, da Dra. Lotte Köhler (neta mais velha de Carlota), da Família Carvalhaes (atual proprietária da fazenda Ibicaba), etc., em 2005. A narrativa informal da filha da moça alemã adotada, que pertenceu ao circulo dos donos do poder, na época do Brasil Império, detalha o cotidiano, enfocando os senhores da propriedade, os imigrantes, os escravos, as festas tradicionais, o relacionamento entre as classes, os visitantes ilustres, com entusiasmo e com franqueza juvenil.

- Depoimento Oral DO-5 - Narrativa em DVD da Doutora Lotte Köhler (neta mais velha de Carlota), psicanalista com 80 anos na ocasião, atualmente (2007) residente em Munique, para o lançamento do livro DE-4 em 16 de Junho de 2005, no Goethe Institut, em SP, com sua construção narrativa dos acontecimentos. Relata a história da alemã mãe solteira, que partiu com a filhinha para construir sua vida no Brasil, sua morte, a adoção da criança, a história da família, a tentativa e a frustração (devido à versão oficial dos fatos) de publicar as memórias e a felicidade de, finalmente, poder realizá-la. 
- Depoimento Oral DO-6 - Gravação em VHS do evento de lançamento do Projeto Memória Limeirense pelo Projeto Imigração Resgate, em parceria com a Secretaria da Educação de Limeira, no anfiteatro de ISCA Faculdades, em 8 de Junho de 2006. Foram homenageados 130 colaboradores, que receberam certificados de honra ao mérito - entre eles esta pesquisadora. O projeto capacitará docentes para o ensino da história da imigração européia e do povoamento que deu origem a Limeira, para 25 mil alunos da rede municipal. Trata-se de um importante registro de narrativas orais do pesquisador José Eduardo Heflinger Jr. e das autoridades públicas locais e nacionais em torno da identidade Limeirense e Brasileira.

- Depoimento Oral DO-7 - Gravação em DVD de entrevista concedida pelo pesquisador José Eduardo Heflinger Jr. à TV Jornal de Limeira no Programa Fatos e Noticias de 18 de dezembro de 2006, sobre a publicação de seu novo livro: "Ibicaba: o Berço da Imigração Européia de Cunho Particular", com o apoio da lei Rouanet, em Junho de 2007, para o qual coletou dados nos Arquivos dos Castelos na Alemanha, em Portugal, em 2006, e no Arquivo do Estado de São Paulo. Revela outras facetas da identidade da família Vergueiro, enfatizando que não quer proceder a qualquer tipo de julgamento.

- Documento Escrito DE-8 - Cópias Parciais de Dois Avisos do Livro de Avisos Imperiais do Arquivo do Estado de São Paulo, datadas de 15 de Fevereiro de 1844 e 7 de Janeiro de 1845, cedidas pelo pesquisador José Eduardo Heflinger Jr., que fazem parte dos documentos apresentados em seu novo livro. No primeiro aviso, a Marinha de Sua Majestade Britânica apresou um navio pertencente a Vergueiro, carregado com 600 escravos e está notificando o Governo Imperial do Rio de Janeiro a respeito. No segundo aviso, informações acusando o Senador Vergueiro de Negociante de Escravos e coparticipante de um esquema de corrupção são repassadas, pelo Governo Imperial, para a Presidência da Província de São Paulo. 


\subsection{Organização da Dissertação:}

Após a introdução acima em 1, que apresenta várias facetas de identidade desta pesquisadora em alguns de seus contextos e, conseqüentemente, situa o foco da dissertação e a comunidade pesquisada, nas questões que envolvem a linguagem, que está por trás de nossas narrativas vivenciadas de identidade, passamos a investigar, no item 2, algumas inquietações teóricas que formam a linha de conduta deste estudo.

Em 2.1, discorremos sobre o caráter performativo que trespassa toda a linguagem (Cohen 2002; Butler 1990) e, portanto, flui em constante movimento, desembocando em 2.2, na busca pelo mito da língua-franca, pelo ideal de construirmos algo em comum (Steiner 1975), sendo que esses dois conceitos lidam com a busca pela identidade. Em 2.3, procuramos abordar, de forma mais detalhada, a questão do complexo da linguagem que não é transparente, que não pode ser reduzida à sua forma escrita nem oral (Bakhtin 1988; Vygotsky 1993; Derrida 1978). Portanto, em 2.4, explicamos, em detalhes, 0 conceito de mente corporificada desde Descartes, passando pela fenomenologia (Husserl 1913; Heidegger 1928; Merleau Ponty 1945), desembocando nas conclusões das ciências cognitivas (Varela 1992; Lakoff \& Johnson 1999) em a); em b) explicamos o conceito de corpo mídia (Greiner 2005); finalizamos em c), com as implicações que tais conceitos trazem para o complexo da linguagem formado por vivências de corpo, alma e espírito (Gil 1997; Nee 1989). Em 2.5, procuramos demonstrar a interação do contexto com as vivências desta mente corporificada (Bakhtin 1988; Lemke 1997).

A partir de 2.6, propomos compreender a narrativa como construção de significação: em a) contrastamos o pensamento lógico-científico com o narrativo e demonstramos que ambos são construções vivenciadas, que a narrativa é semiose, pensamento, construção da realidade, o próprio processo de significação (Bruner 1986, 2001); em b) tratamos da narrativa como processo de ação social e cultural (Klapproth 2004), portanto criação de significação em constante movimento contextualizado (Brockmeier \& Harré 2005; Vieira 2005); em c) explicamos que praticamente não existe diferença 
entre narrativas reais e imaginadas (Klapproth 2004), pois ambas são, também, construções vivenciadas; em d) enfatizamos o caráter de busca existencial que a narrativa apresenta e discorremos sobre as implicações de exercer o direito de narrar, o direito de buscar uma identidade (Bhabha 2001).

A partir de 2.7, passamos a lidar com a identidade como teia de significação: em a) abordamos o fato da crise de identidade (Hall 2001) propiciar diversos processos de identificação (Lacan 1988), que evoluem em b) para a idéia de construção de identidades nacionais (Hall 1997), em c) entra em discussão, o hibridismo (Bhabha 1994), como coexistência de valores diferentes num terceiro espaço, que está presente em todas as identidades e, finalmente, em d), focalizamos o imigrante e suas contradições (Sayad 1998).

Em 3, analisamos as narrativas vivenciadas da comunidade pesquisada com base nas inquietações teóricas discutidas em 2 e as implicações para a comunidade até os dias de hoje. Iniciamos em 3.1 com o polemico mentor da imigração de cunho particular, e ou escravagista, o Senador Vergueiro, proprietário da fazenda Ibicaba, palco dos acontecimentos analisados, e sua vivência de grande narrativa nacionalista a partir de seu ponto de vista de inclusão e pertencimento. Passamos, então, a visualizar, em 3.2, a posição de imigrante como incômodo e deslocamento do colono Thomas Davatz, mestre escola suíço, democrático, e ou anarquista; em 3.3 analisamos a singular e bem sucedida família Levy, sua visão de imigrantes progressistas, que de colonos passaram a proprietários de Ibicaba; em 3.4 contrastamos a identidade de José Vergueiro a partir das recordações de infância de sua neta Carlota Schmidt - filha da filha adotiva alemã de José Vergueiro - e o hibridismo patente nessa relação e, em 3.5, a versão da Dra. Lotte Köhler , psicanalista com 80 anos, neta de Carlota, que vivencia o hibridismo no nosso aqui e agora contemporâneo, sobre a construção histórica européia dos acontecimentos em torno da imigração de cunho particular para a Ibicaba cafeeira do século XIX. Em 3.6, abordamos o pesquisador Jose Eduardo Heflinger Jr. que, como narravinte da Dra. Lotte, obteve o direito de renarrar a versão nacional e internacional dos acontecimentos, que culminou na reconstrução, em 3.7, das 
identidades limeirense e nacional, a partir do reconhecimento internacional do direito de narrar.

Em 4, procederemos às inquietações finais que nos levam a concluir que, diante da indeterminação e da contingência, há a crise de identidade em todos nós e que várias "verdades" são construídas em teias de significação, sóciohistórica e culturalmente, a partir de seus contextos, em interação com seus momentos performativos e que 'as identidades são um complexo de narrativas vivenciadas, formadas nas zonas híbridas de encontro de culturas' (Bhabha 1994). As identidades paradoxais dos membros da comunidade pesquisada são, apenas, algumas das diversas identidades ou identificações vivenciadas de corpo, alma e espírito, que convivem em negociação no terceiro espaço, onde as verdades são desconstruídas e confrontadas diante da performatividade, do direito de significar do outro, do direito de buscarmos nossa língua-franca e de sermos ouvidos.

O uso de negrito ao longo da dissertação procura imprimir certo ritmo à leitura, visando destacar as inquietações e reflexões que ora evidenciam o que se está tentando explicar. Ritmo esse, que se assemelha ao ideograma chinês, que embora destituído de qualquer som, lida com a significação primeiramente através do impacto visual, como um sinal de trânsito ou a poesia concreta.

\title{
2. ALGUMAS INQUIETAÇÕES TEÓRICAS
}

\begin{abstract}
Clarity is of no importance because nobody listens and nobody knows what you mean no matter what you mean, nor how clearly you mean what you mean. But if you have vitality enough of knowing enough of what you mean, somebody and sometime and sometimes a great many will have to realize that you know what you mean and so they will agree that you mean what you know, what you know you mean which is as near as anybody can come to understanding anyone. $^{3}$

(Stein 1975, XXV)
\end{abstract}

3. Claridade é de importância nenhuma, porque ninguém ouve e ninguém sabe o significado que você diz; não importa o significado que você diz, nem quão claramente você significa o que você significa. Mas, se você tiver vitalidade suficiente para saber suficientemente o significado que você diz, alguém e alguma hora e outras horas muitos terão de perceber que você sabe o significado que diz e, portanto, eles concordarão que você significa o que você sabe, o que você sabe que significa, que é o mais próximo que alguém pode chegar a compreender o outro. (tradução nossa) 
Ao modo de Stein, tentaremos demonstrar, com vitalidade o suficiente, ao longo deste capitulo, o que queremos significar em termos de teoria com relação à complexidade da linguagem, a saber, inicialmente discutiremos o caráter performativo da linguagem, sua flexibilidade e sua multiplicidade, presentes no aqui e agora de nossa performance diária, ou seja, seu principio de constante ação e reflexão. Discorreremos, a seguir, sobre a busca por uma língua franca, que pudesse ser compreendida por todos e que rompesse todas as fronteiras, integrar a mente - corpo, alma e espírito -, numa comunhão total, onde linguagem e pensamento seriam unidos em um entendimento além da consciência, como reflexo de nossa busca por uma identidade ontológica. Tal possibilidade persiste como uma sombra por trás de toda a linguagem, ou como um ideal a ser alcançado.

\subsection{A Performatividade da Linguagem}

Nossa comunicação acontece através de uma ação, tão importante quanto à representação sígnica de conceitos e de idéias, são os universos semióticos paralelos e a participação das pessoas que interagem entre si em um determinado tempo e espaço, vivenciando a influência de seus contextos socioculturais e sua história (lazzetta 2004). Participamos de um movimento cósmico, discernível no movimento dos astros celestes e na diversidade das estações, com nosso movimento humano, que une a natureza incorpórea da razão ao corpo através de sua harmonia e, no entanto, somos o único ser capaz de viver em desarmonia com a natureza, interferindo nela de forma destrutiva, capaz de provocar o aquecimento global; nossas performances técnica e tecnológica interagem na nossa prática social como atores que somos.

Performance como "atuação" ou "desempenho" no aprendizado da vida está carregada de sentido ontológico, trata-se de uma vivência que ocorre num espaço/tempo intersticial entre a diversidade de papéis e a complexidade de identidades que representamos diariamente. Viabiliza um cruzamento sinestésico/cinestésico de linguagens do qual dispomos para lidarmos com 0 
mundo empírico do aqui/agora, um mundo polifônico e aberto. Nossa performance/atuação diária ocorre na fronteira entre o teatro e a vida.

Em "Performance como linguagem", Cohen (2002) propõe um paralelo muito sutil entre a arte e a vida. Ao valorizar o aqui/agora, a vivência do instante presente, a performance rompe com a representação, abre espaço para o imprevisto, busca o desenvolvimento pessoal, é um laboratório, um palco de experiência ou de tomada de consciência para utilização na vida. O que aconteceria se conseguíssemos romper com a representação e tomássemos consciência do complexo de identidades que nos dilacera?

As indagações de Cohen (1998) acerca de processos de ação passam a investigar o procedimento Work in Process/Progress que carrega a noção de trabalho (obra acabada como resultado, produto e, também, percurso, processo, obra em feitura) e processo (iteratividade, permeação, risco, obra aberta ao modo de Umberto Eco, em Lechte 1994) investindo-se na idéia de dinamicidade de sistema. Existe um Subject in Process (Kristeva, em Lechte 1994) aberto a mudanças na personalidade pela experiência. Ou seja, trata-se do nosso processo de vida, de formação de identidade.

Nossa performatividade é um processo lingüístico e também nãolingüístico, alavancado pela interconexão dos nossos dados sensoriais, nossos sentimentos, nossas interpretações e nossos desejos que permeiam nossas ações, trata-se da vivência, de lidarmos com o significado da vida. Ao discutir nossa performatividade, Butler (1990) explica que não se trata do que alguém é, mas do que faz. Compreendemos, portanto, que um ato performativo desempenha o ato da fala como vivência da identidade, são representações performativas do sujeito. Nossa vivência da identidade, no diaa-dia, é perpassada por inúmeras representações performativas do sujeito, ainda assim, ansiamos pelo mito da língua-franca.

\subsection{A Busca pela Língua-Franca}

Nossas possibilidades de comunicação, ampliadas pela globalização e pela Internet, levam-nos a vivenciar realidades virtuais e multifacetadas 
passivamente. Ao ficarmos sabendo de tudo ao mesmo tempo e tomarmos consciência da multiplicidade de significados que podem ser atribuídos a uma mesma realidade, vivemos a exacerbação do mito de Babel (confusão de línguas), onde duas pessoas que falam a mesma língua, trabalham na mesma área ou dividem o mesmo leito, muito provavelmente não se entendem por atribuírem significados diferentes a uma mesma palavra, sem mencionar o jargão envolvido em qualquer tipo de especialização.

\begin{abstract}
"Não são apenas os surdos que não conseguem se entender, mas quaisquer pessoas que atribuem um significado diferente à mesma palavra, ou que sustentam pontos de vista diferentes."
\end{abstract}

(Vygotsky 1993:122, grifo nosso)

Em contrapartida, vivemos a busca pelo mito da "língua-franca", a língua/linguagem original e única, a Ursprache de Adão, aquela que é compreendida por todos e rompe todas as fronteiras, integra a mente - corpo, alma e espírito - em uma comunhão total, onde linguagem e pensamento são unidos em um entendimento além da consciência, como reflexo de nossa busca por uma identidade ontológica. Ao pensarmos em termos de linguagem humana efetiva de comunicação, além da apenas oral ou escrita, invadimos o campo dos sentidos, da percepção e das emoções, como destaca Steiner:

\begin{abstract}
"Guerras santas e a perseguição de supostas heresias surgem inevitavelmente da babel de línguas: os homens equivocam-se e adulteram os significados uns dos outros. Mas há um caminho para fora das trevas: o que Böhme chama de 'linguagem sensualista' - a linguagem instintiva, imediata, não ensinada, a linguagem da Natureza e do homem natural como a que foi outorgada aos Apóstolos, pessoas humildes, no Pentecostes."
\end{abstract}

(Steiner 1975:62, tradução e grifo nosso)

O que seriam a babel de línguas e a língua utilizada no Pentecostes? Segundo o Gênesis da Bíblia, após o dilúvio, os homens cuja confusão ou pecado original era estar separados de Deus e acreditar em si, na sua ciência e 
conhecimento do bem e do mal, ainda falavam uma mesma língua e juntaramse para realizar o feito impossível de construir uma torre que alcançasse os céus e, dessa maneira, poder igualar-se a Deus. Este, diante de tal absurdo, percebeu que não haveria restrição para tudo que intentariam realizar, achou por bem confundir suas línguas e espalhá-los por toda a terra; por isso, chamou-se torre de Babel. Essa confusão em que vivemos seria uma espécie de técnica que evita confusões maiores, um caminho para percebermos nossa impotência enquanto meros humanos mortais e procurarmos voltar à harmonia pré-babélica e à comunhão com Deus; nosso pecado original, ou seja, a separação de Deus e, conseqüentemente, a morte, entra no mundo por um homem, Adão, e a religação, ou salvação, se estabelece através do sangue de outro homem, Cristo, o qual é também Deus e o Espírito Santo, que, por amor, nos restitui a vida eterna.

Assim, no dia de Pentecostes, após a morte de Jesus, estando os apóstolos reunidos num mesmo local, veio do céu um som e foram cheios do Espírito Santo, passando a falar em outras línguas, e cada um da multidão que se ajuntou os ouvia falar, na sua própria língua, das grandezas de Deus. Para acabar com a confusão, surge uma solução integrativa, holística, universal, divina. O plano de Deus seria acabar com tudo que divide o ser humano: classes sociais, culturas, nações e religiões. No amor de Deus, na sua comunhão espiritual, a complexidade torna-se simplicidade e a multiplicidade torna-se unicidade.

Esses dois momentos bíblicos, Babel e Pentecostes, lidam com nossa problemática básica que transita entre a multiplicidade e a unicidade de significado, de identidade, de ser e existir. Lidam com nossa necessidade de construir significados em comum, com o mito da transparência da linguagem, com a busca pela identidade. Lidam com a busca por uma língua-franca capaz de nos proporcionar uma comunhão espiritual, que é muito mais que o intercâmbio de idéias e opiniões, é a interação de mentes enquanto corpo, alma e espírito. Babel e Pentecostes estão por trás da linguagem como uma sombra ou um ideal a ser perseguido. 


\subsection{O Complexo da Linguagem}

\author{
"A word is dead \\ When it is said, \\ Some say. \\ I say it just \\ Begins to live \\ That day."
}

Emily Dickinson
A palavra é morta

Quando é dita

Dizem uns.

Eu digo: apenas

Inicia a viver

Tal dia.

(tradução nossa)

A ambivalência presente no poema de Emily Dickinson nos remete a questões paradoxais da linguagem: a palavra morreria ou viveria ao ser pronunciada? Enquanto seres viventes em constante processo performativo, questionamos paradigmas constantemente, mas, mesmo assim, procuramos uma resposta, procuramos uma língua-franca. Demonstraremos, neste item, que o complexo da linguagem vai muito além da apenas oral ou escrita, que envolve processos sinestésicos e cinestésicos de um corpo contextualizado e que o sujeito por trás da fala não é apenas um corpo, ou um cérebro, mas uma mente corporificada que vivencia processos de significação de corpo, alma e espírito.

Seria a linguagem abstrata, homogênea, transparente, representativa de uma realidade universal e a forma escrita como seu ápice (de acordo com culturas ocidentais), um reflexo mimético do real? Bastaria o processo de significação, a vivência da identidade ser reduzidos a significante e significado, a língua e fala?

Certos postulados e "verdades", valores e ideologias que vivenciamos, social e culturalmente, os quais são construídos ao longo de nossas histórias / estórias, certas "grandes narrativas" têm o hábito de se tornarem inquestionáveis; portanto, necessitamos percorrer um caminho extenso e complexo para desconstruirmos tais processos e percebermos quão intricadas e comprometidas as lógicas dos nossos pensamentos estão, a fim de repensálos, de resignificá-los e de reconstruí-los sob outra perspectiva. Nesse aspecto, o pós-estruturalismo é um alerta, uma conscientização. 
Bakhtin (1988) critica a visão estruturalista de Saussure (1974), visão predominante da linguagem em que esta se abstrai de seu contexto social e é tratada como sistema, estrutura fechada, reduzindo e simplificando sua riqueza. Critica e nega a possibilidade de abstração da linguagem, pois esta é ideologia, história, valores sociais, lingüística e não-lingüística. Linguagem enquanto significação, construção de sentidos é sempre mediada pelo usuário. A língua é sempre heterogênea, tem significados diferentes para pessoas diferentes em momentos diferentes.

Para Saussure, a língua era um sistema e a fala um desvio, os usuários reais eram desvios, enquanto, para Bakhtin, cada um de nós é construído por vários fatos sociais, cada usuário real, uma regra, a linguagem é transliterária, abolimos zonas limítrofes e fazemos outras conexões textuais; ela é um fato social múltiplo, heterogêneo e complexo com regras sociais contextualizadas, somos todos multilíngües. Seu dialogismo nos conscientiza de outras vozes que formam a nossa, das esferas do extralingüístico. Enquanto Saussure defende um signo representacional, carregado do conceito de substituição, de estar no lugar de, Bakhtin questiona para quem o signo é convencional se temos uma multiplicidade de convenções, signo não é sinônimo de símbolo.

De acordo com o conceito sócio-construtivista de Vygotsky (1993), a percepção da realidade é construída através da linguagem, a identidade vem do meio, o contexto varia e não nos determina, mas predispõe. Segundo ele, a lingüística não percebeu a evolução histórica da linguagem, na qual a própria estrutura do significado e sua natureza psicológica mudam. Não apenas o conteúdo de uma palavra se altera, mas o modo que a realidade é generalizada e refletida nela. Na escrita, excluímos o tom de voz e o conhecimento do assunto, o que nos obriga a utilizar muito mais palavras e com maior exatidão. A escrita é a forma de fala mais elaborada. O pensamento, diferente da fala, não consiste em unidades separadas. Na vida real, todas nossas frases possuem um tipo de subtexto, um pensamento oculto. O pensamento é gerado pela motivação, por nossos desejos e necessidades, por nossos interesses e emoções. Apenas podemos compreender 0 
pensamento do outro quando entendemos sua base afetivo-volitiva. A relação entre o pensamento e a palavra é um processo vivo, a palavra é microcosmo da consciência.

Vygotsky (1993) chama a atenção para o predomínio do sentido de uma palavra sobre seu significado: aquele é a soma de todos os eventos psicológicos que a palavra desperta em nossa consciência, um todo complexo, fluído e dinâmico, com várias zonas de estabilidade desigual; este, apenas a mais estável e precisa. Uma palavra adquire o seu sentido no contexto em que surge; em contextos diferentes, altera seu sentido.

Ao apontar o caminho da desconstrução para compreendermos que nossos mundos são uma construção da linguagem, uma ilusão da realidade, uma interpretação, um texto com uma teia de significados diferentes de sua origem, Derrida (1978) explica que as culturas ocidentais são ontologias fonocêntricas, mas que se gabam de serem escritas. A escrita representa a fala e a fala representa o pensamento e, para compreendermos o pensamento, precisamos buscar a voz da pessoa, a presença. O texto congela a fala, congela a intenção do falante, a escritura seria o momento máximo da manifestação do pensamento da origem da presença, registrada no papel. O significado é sempre adiado e não há garantia de origem, pois o âmago é contingente.

Para o historiador de arte Gombrich (2007), não vemos a realidade com os olhos, nós a construímos com nossas mentes e com nossa cultura. O mundo não existe independente de nossa cultura, de nossa linguagem. Atualmente, a linguagem verbal tem cedido cada vez mais espaço para outros gêneros textuais, sejam paginas da web, textos visuais ou performativos, resgatando a idéia de uma comunicação mais plena. Por outro lado, vivemos um momento virtual e descorporificado na educação e, nesse sentido, é preciso resgatar a sinestesia/cinestesia corporal e o processo vivencial no ensino/aprendizagem/entendimento da linguagem. 
Seria nossa comunicação com o mundo descorporificada, fruto de um processo racional destituído de vivências sinestésicas/cinestésicas? Como discutíamos, nossa presença no mundo, nossa vivência, o complexo da linguagem, não podem ser reduzidos à língua falada ou escrita, envolve, também, o processo de sinestesia/cinestesia do nosso corpo no mundo através do qual percebemos o mundo. Nossa mente não é apenas um cérebro, envolve um complexo de vivências de corpo, alma e espírito como demonstraremos a seguir.

\title{
2.4. A Mente Corporificada
}

\begin{abstract}
"Ao descrever o uso de símbolos, estaremos também descrevendo percepções, sentimentos, pontos de vista, experiências? Se afirmativo, em que sentido? O que é exatamente que afirmamos quando declaramos compreender os meios semióticos através dos quais, nesses casos, as pessoas se definem e são definidas pelas outras: que entendemos as palavras ou que entendemos as mentes?"
\end{abstract}

(Geertz 1973:104, tradução nossa)

Ao percebermos o mundo através de processos sensoriais, utilizamo-nos de símbolos para construir significados; será que compreendemos o significado do outro através de suas palavras ou entendemos sua mente com a interpretação da nossa mente?

O que é e onde se situa a mente? Mente, como intelecto, pensamento, entendimento; alma, espírito; ou concepção, imaginação, intenção, desígnio (Aurélio 1975), em termos de materialidade, no Ocidente, muitas vezes, é reduzido a um cérebro, e, no Oriente, a um coração. Novamente, o desconstrucionismo de Derrida $(1974,1978)$ nos instiga a demolir paradigmas e, ao mesmo tempo, a estar aptos ao exercício da reconstrução; afinal, enquanto seres viventes, nosso processo de ação é a construção. Munidos dessa ferramenta, procuraremos investigar algumas perspectivas em torno da questão acima.

Descartes (1596-1650) posicionou a questão ontológica da filosofia em um dualismo: a relação entre o pensamento e o ser. Passou a entender o corpo 
como aquilo que tem extensão temporal e espacial (res extensa), a alma como pensamento (res cogitans). Considerava essas duas substâncias, princípios independentes: um material e outro espiritual. Plenamente convencido do potencial da razão humana, propunha-se criar um método novo, científico, do conhecimento do mundo e substituir a fé cega pela razão e pela ciência. Recorre à dúvida como método de raciocínio para livrar-se de todas as idéias pré-concebidas da exatidão das nossas representações do mundo e do próprio mundo. Duvidar significa pensar - "penso logo existo" (cogito ergo sum) - , para ele os sentidos nos dão uma representação confusa dos objetos e o critério da verdade encontra-se na razão. A razão pretendia libertar-se de superstições e de preconceitos e voltar-se para a observação de fatos concretos, acelerando a evolução do pensamento científico. Para Descartes, a dúvida se transformou em certeza; o eu, garantia. Devido a seu lócus de enunciação, não partiu da perspectiva de que a linguagem é também vivência sinestésica do contexto sócio-cultural e ideológico.

Numa outra perspectiva, a fenomenologia considera o mundo pré-reflexivo, determinado pelos fatos, pelo sentido, estudando a relação entre a percepção e a consciência. O homem é corpo e consciência, presente no mundo e consciente de sua própria existência. Na língua alemã via Husserl (1913), assim como a grega (soma - corpo morto e demas - corpo vivo), conhece dois termos pra se referir ao corpo: Körper, refere-se a aspectos estruturais do corpo e cadáver; Leib, refere-se ao corpo vivo, com sentimentos, sensações, percepções e emoções. Heidegger (1928) desenvolve tal fenomenologia em ontologia, a subjetividade e o mundo passam a ser dasein, existência humana, ser-no-mundo, deslocando a questão do corpo para a incorporação/corporificação: "Não temos um corpo, mas somos incorporados/corporificados".

Merleau-Ponty $(1945,1961,1984)$ faz uma síntese entre esses dois pensamentos, introduz a noção de carne, o homem como ser no mundo tem um enraizamento da consciência no próprio corpo, observa que o movimento já é conhecimento, senso prático: "meu corpo é a textura comum de todos os objetos e é, pelo menos com relação ao mundo percebido, o instrumento geral 
de minha 'compreensão'". Propõe a compreensão das relações entre consciência orgânica, psicológica e social, fundadas na percepção da experiência vivida. Sem separar corpo de mente, propõe uma visão integradora de corpo contextualizado em uma relação viva e dinâmica. A construção é um processo repleto de uma multiplicidade de motivações e de experiências sinestésicas e cinestésicas. Existe uma empatia de presentificação no movimento, o conhecimento do nosso corpo contém o corpo do outro, a experiência individual faz parte do universo de experiências coletivas, dos corpos em constante interação. O corpo é uma transcendência manifesta e expressa na relação com o mundo. Compreender o ser humano é vê-lo como ser-no-mundo, como existência e significação. Há uma unidade do corpo que não é apenas uma soma de sensações táteis ou cinestésicas, mas um "esquema corporal" que engloba a consciência de nosso corpo no espaço, ou a correlação com o mundo exterior, e, também, a unidade de todos os dados sensoriais.

Langer (1971) explica que nossas idéias surgem a partir de impressões, de mensagens sensoriais dos órgãos especiais de percepção e de vagos registros viscerais de sensação. A ideação ocorre por um principio de simbolização. A fala é a mais imediata terminação ativa desse processo no cérebro humano que podemos denominar transformação simbólica de experiências. As palavras como o ritual e a arte são nossos instrumentos de expressão, são as terminações ativas de uma transformação simbólica da experiência.

\section{4.a. As Conclusões das Ciências Cognitivas}

As ciências cognitivas afirmaram-se como a construção de uma nova ciência dos fenômenos constitutivos dos aparelhos e os comportamentos psicobiológicos, das interações entre esses aparelhos e os comportamentos humanos, no que se refere, também, às suas formas altamente simbólicas, tais como as linguagens e as culturas. Com o objetivo de compreender a inteligência humana, as ciências cognitivas têm a finalidade de descrever, de explicar e, eventualmente, de simular as principais disposições e capacidades 
do espírito humano - linguagem, raciocínio, percepção, coordenação motora e planificação.

Podem ser vistas como uma nova ciência do espírito que, para além da vertente cientifica e descritiva, não negligencia a vertente filosófica. Unidas pela preocupação comum com as relações espírito/cérebro, mente/cérebro, com as modelizações possíveis dessas relações com a análise dos funcionamentos aí implicados, ou com as condutas daí derivadas, as disciplinas diretamente ligadas às ciências cognitivas são as neurociências, a inteligência artificial, a filosofia, a psicologia e a lingüística.

Quando filósofos, lingüistas, engenheiros e cientistas da computação começaram a falar em "ciência cognitiva", eles tinham a idéia de cognição como sendo uma representação mental, tendo o computador como metáfora do conhecimento, como representação mental de símbolos computáveis, o que significa uma simplificação do processo pelo qual experienciamos e entendemos o mundo. Trata-se de uma visão que idealiza um tipo de racionalismo que paira acima de nossa presença no mundo e ignora as relações concretas e brutas que envolvem nossa vivência. Como se dá o trânsito entre as informações do mundo e as informações residentes no corpo? Passaram, então, a ampliar perspectivas.

Varela, Thompson \& Rosch (1992) explicam que o conhecimento não acontece apenas através da razão, mas também através de um processo muito mais rico de imersão no universo dos signos, que leva em conta a presença do corpo que vivencia esses processos. A maneira como interagimos com o mundo e o conhecimento que temos dele depende de serno-mundo (being-in-the-world), da vivência corporificada (embodiment) que não pode ser separada de nossos corpos, de nossa linguagem e de nossas histórias sociais. A ampla compreensão de nossas estratégias cognitivas não pode estar atada à rigidez de uma realidade pré-estabelecida, independente de nossas capacidades sensoriais, perceptivas e cognitivas. Conhecimento se dá através de uma ação corpórea (embodied action), através de nossa performance, atuação (enaction) no mundo. 
A experiência é um fato concreto e sensório-motor, é a base do pensamento, aquilo que conhecemos é deduzido através dela. Trata-se de um autoprazer, uma emoção fisiológica que se transforma em memória, é um processo que envolve transformação do potencial em real, uma possibilidade de confrontar velhos paradigmas e o novo material experimentado.

Nossa comunicação é notadamente corpórea, pois é fruto dos corpos que a produzem, nosso gesto é um movimento capaz de expressar algo, desempenha papel primordial como gerador de significação. Ações como girar botões ou acionar alavancas são atos correntes no uso da tecnologia moderna, mas não podem ser consideradas como gestos em um sentido amplo do termo. O distanciamento entre corpos é reforçado pelo uso de computadores, evitando um confronto pessoal da presença, eliminando a existência e a performance. O computador forçou uma base comum de comunicação, sua multiplicidade impôs uma onipresença comunicacional em todos os seus níveis de operação, entretanto ainda está distante do nível de interação gestual que experimentamos quando nos relacionamos com outras pessoas.

$\mathrm{Na}$ experiência humana, corporificar é ser um corpo e estar inserido corporalmente no contexto biológico de um ambiente que é também cultural e psicológico (Romano 2004). Dessa forma, conhecimento diferencia-se de representação (ou construções simbólicas da realidade a ser representada) e aproxima-se da idéia de ação corporificada. Para o embodiment (vivido, corporificado), o corpo humano contextualizado possibilita, na relação com o ambiente, a emergência de um comportamento. Segundo Lakoff \& Johnson $(1999,2002)$ a mente é inerentemente corporificada, o pensamento é basicamente inconsciente e os conceitos abstratos são amplamente metafóricos.

Na concepção tradicional ocidental, a razão é literal e descorporificada. Mas os autores explicam que, a partir do grego, a palavra metáfora significa "transferência ou transporte"; mais que palavras, ou uma figura de linguagem, ela é pensamento e ação. Nosso sistema conceitual é metafórico por natureza, estrutura parcialmente uma estrutura em termos de outra. Ao 
conceituarmos, o transporte de informações é de natureza metafórica. A comunicação cria metáforas organizando o trânsito entre ação e palavra, dentro e fora do corpo.

Eles propõem um diálogo entre filosofia e ciências cognitivas, uma filosofia empiricamente responsável. As principais formas de inferências racionais são instâncias de inferências sensório-motoras. Pelo fato de nossas idéias serem formadas com base em nossos sistemas conceituais corporificados e inconscientes, a verdade e o conhecimento dependem da compreensão corporificada. Razão e conceitos derivam e fazem uso do sistema sensóriomotor, portanto a mente não é separada, nem independente do corpo.

O próprio conceito de espiritualidade, em nossa cultura, é definido, principalmente, em termos de descorporificação, ou transcendência deste mundo, mas o que se faz necessário é uma concepção alternativa de espiritualidade corporificada que, ao menos, comece a fazer justiça ao que as pessoas vivenciam. Afinal, a mente não é apenas corpórea, é também passional, munida de desejos e social, tem uma cultura, uma história, em processo. Tem um aspecto inconsciente, mas aquilo que pensamos ser cabe ao caráter consciente; portanto, a mente é limitada, mas expansível. A mente corporificada é empática, desde que nascemos temos a capacidade de imitação, de imaginarmos vividamente que somos outra pessoa; esta capacidade de projeção imaginativa é uma faculdade cognitiva vital, experiencialmente é uma forma de "transcendência". A projeção empática imaginativa é uma parte principal da chamada experiência espiritual. Através dela conhecemos nosso ambiente que é o local da nossa existência e da nossa identidade; uma espiritualidade corporificada é uma espiritualidade ecológica, a natureza não é inanimada e menos que humana, mas viva e mais que humana. Segundo Lakoff \& Johnson (1999), a espiritualidade corporificada é mais que uma experiência espiritual, é uma relação ética com o mundo físico.

A partir da antropologia médica, Ots (1994) argumenta que apenas a vida é capaz de tornar a mente potencialmente ativa e, no entanto, a mente, enquanto expressão de estruturas culturais e de relações sociais, impõe inúmeras restrições e limites ao Leib (corpo vivo), como se fosse existencialmente 
independente de todos os parâmetros de vida orgânica. Csordas (1994) explica que estudos culturais interdisciplinares nas ciências humanas, diante do desconforto de toda atividade intelectual frente à condição pós-moderna, voltaram-se para o corpo, como se este pudesse ser um centro estável diante de um mundo de significados descentrados, para, apenas, descobrirem que a característica essencial da corporeidade é a indeterminação existencial. Para Turner (1994), o corpo tornou-se uma arena de conflitos sociais e de controles repressivos, mas, ao mesmo tempo, um dos aspectos mais libertadores da cultura e da vida social contemporâneas.

\section{4.b. O Corpomídia}

"Para tratar do corpo, não basta o esforço de colar conhecimentos buscados em disciplinas aqui e ali. Nem trans nem interdisciplinaridade se mostram estratégias competentes para a tarefa. Por isso, a proposta de abolição da moldura de disciplina em favor da indisciplina que caracteriza o corpo"

(Katz, 2004 apud Greiner 2005:12)

Greiner (2005) faz uma contribuição significativa para o entendimento da gênese e da migração de algumas das principais teorias sobre o corpo, da intersecção entre vida e pensamento e, em parceria com Katz, propõe o corpomídia: o movimento como matriz da comunicação, o corpo é mídia de si mesmo; na sua indisciplina, todas as disciplinas convergem no "processo evolutivo de selecionar informações que vão constituindo o corpo. A informação se transmite em processo de contaminação"; na interação com o ambiente somos transformados, a cultura é um sistema aberto que contamina o corpo e é também contaminado; no corpo o relacionamento entre natureza e cultura é explícito, nele ocorrem contínuos acordos entre mecanismos de produção, armazenamento, transformação e distribuição de informação. O corpo é e está no mundo em tempo real, quando entendemos algo e ainda não sabemos falar sobre o que se passa, o presente já passou e também está em andamento, suspendendo e esgarçando o tempo, nossa percepção inventa o mundo, nosso corpo fica diferente com a 
experiência e devolve diferente, cada corpo conserva informações diferentes e as transforma, pois é transformado; estamos e somos corpos vivos em transição, carregados de significação.

\section{4.c. O Sujeito da Linguagem: Corpo, Alma e Espírito}

Segundo Gil (1997), a relação indicada pelo corpo do outro inaugura uma diferença irredutível: entre o que se mostra e o que se esconde, em nível mesmo da percepção simples. Percepcionar um corpo outro significa sofrer uma esquiva e compensá-la com um equívoco. Esquiva significa que a vivência do outro escapa à minha vista, esgueirando-se por entre sinais visíveis - expressões do rosto, gestos, palavras, movimentos do corpo. A relação de signo ou relação semiótica começa por um equívoco: tomar-se o exterior pelo interior.

O autor questiona: onde se situa o interior? Onde o olhar que vê o corpo expressivo do outro vai fixar o seu interior? Para além dos ouvidos que são órgãos sensoriais, fala-se para outra coisa, que é o que no outro me pode compreender, o seu espírito. Podemos dizer o mesmo a respeito de um olhar ou de um abraço de amizade, não olhamos os olhos do outro, mas para seu interior, não abraçamos o corpo do outro, nem apenas a alma. O sujeito da percepção situa-se no limite, na zona fronteiriça, no espaço das metamorfoses do exterior em interior, do corpo em espírito de uma percepção externa em imagem interna.

Essa tradução recíproca do espaço limiar encontra-se em todas as suas modalidades sensoriais: no espaço auditivo, táctil, visual, olfativo, gustativo e na pele enquanto espaço de sobreposição. Ela transforma sua tactilidade em abertura e em transporte entre interior e exterior. Também os orifícios do corpo conduzem a esse espaço, 0 ato sexual que implica penetração, respectivamente entrada em um e abertura de um espaço interno, é vivenciado pelos parceiros como ocupação desse espaço e fluxo de almas por contato, 
contágio e multiplicação de intensidades. No fundo do espaço limiar está a alma, no movimento para, no lugar do infinito, na velocidade expressiva. Assim como respiramos o ar vital $^{4}$ e pulsamos em harmonia com o universo, através da inspiração e da expiração, que gera a energia que nos mantém vivos, esse mesmo movimento e fluxo permeia nossa linguagem, tornando-a dinâmica e transformativa. Essa síntese de respiração em expressão está na base do sentido de ser humano. Meu corpo (a partir do grego soma-morto / demasvivo) manifesta a materialidade do que sou e suas sensações não são independentes dos sentimentos de minha alma (psiqué) e da consciência de meu espírito (pneuma), sendo a percepção, a compreensão e a expressão a manifestação desse complexo interdependente e holístico. A partir do latim corpus e corporis, que pertencem à mesma família de corpulência e incorporar, temos o substantivo corpo.

As antigas expressões hebraicas ruah (espírito) e nefes (alma), ambas, significam o fôlego da vida ou sede dos pensamentos e dos sentimentos. $O$ corpo vivo, como materialidade sensível, é a parte utilizada como fonte de sensações no conhecimento do mundo e, também, para a manifestação de sentimentos e de ações no meio exterior, é o homem periférico. A alma é o lugar da personalidade, da nossa individualidade, do ego, inclui o intelecto, sede dos afetos, desejos, emoções e vontade do homem, o centro da vida moral, o homem exterior. O espírito retém o sentido de sopro, respiração, força vital, dinamismo organizador próprio da vida (grego - alma), elo de contato e de comunicação com o mundo espiritual, consciência de Deus, intuição da ética e da moral, o homem interior. Segundo Nee (1989), o corpo é consciência do mundo; a alma, autoconsciência; o espírito, consciência de Deus. A alma é o ponto de encontro do espírito e do corpo, o espírito nos capacita a nos comunicar com o mundo espiritual, o corpo mantém contato com o mundo exterior e sensual e a alma permanece entre esses dois mundos e, ainda, pertence a ambos, possuindo o livre-arbítrio. Nossa vivência contextualizada pode privilegiar uma das partes, mas flui e é liberada para se comunicar através deste nosso complexo de corpo, alma e espírito.

4. Sopro de Deus na narina de Adão / pneuma para os gregos / prana para os indianos / qi para os chineses. 
Gonçalves (1994) expõe a problemática do homem e sua corporeidade na história do pensamento filosófico, como oscilando entre dois pólos: o corpo e a alma $^{5}$, o conhecimento sensível e o conhecimento inteligível, o mundo da matéria e o mundo do espírito, a vida terrena e a vida ultraterrena. No entanto, concluímos, através das investigações deste estudo, que nossa mente não só é corporificada, mas tal qual nossa vivência, um complexo de corpo, alma e espírito. Nossa comunicação performativa vivencia a interatividade e a emergência do fluxo desse complexo no aqui e agora contextual: ecológico, social, cultural (estético, ético e moral), econômico, político, religioso, que fazem parte da indeterminação e da contingência da identidade.

\subsection{Vivências Contextualizadas}

Vivenciamos nossa identidade de corpo, alma e espírito e, ainda, não existe saber desvinculado do contexto, tudo adquire um valor num contexto: língua, cultura, natureza, tecnologia, afetividade, sentimento, depende da complexidade do valor que atribuímos. Contexto é a interconectividade desses elementos todos; semiose é o processo de construção de significado. Toda cognição é situada, fruto de um determinado lugar e contexto.

Para Bakhtin (1988), é necessário integrarmos a vivência interior e a vivência exterior, pois o funcionamento da consciência não pode ser reduzido aos processos que acontecem no interior do organismo vivo:

\footnotetext{
"A compreensão de cada signo, interior ou exterior, efetua-se em ligação estreita com a situação em que ele toma forma. Esta situação, mesmo no caso da introspecção, apresenta-se como a totalidade dos fatos que constituem a experiência exterior, que acompanha e esclarece todo signo interior. Essa situação é sempre uma situação social. A orientação da atividade mental no interior da
}

5. No Novo Testamento, Paulo, em sua primeira carta aos Tessalonicenses (IT-5:23), refere-se a corpo, alma e espírito; no entanto, alguns pensadores referem-se à dicotomia corpo e alma sendo alma sinônima de espírito. 
alma (a introspecção) não pode ser separada da realidade de sua orientação numa situação social dada."

(Bakhtin 1988:62, grifo do autor)

O discurso interior cruza com reações gestuais, criando um valor semiótico, mas a palavra é o material privilegiado do psiquismo, o fundamento da vida interior, pois se esta fosse excluída, o psiquismo seria quase nada, o que não aconteceria se excluíssemos os outros movimentos expressivos.

Portanto, o psiquismo não é determinado somente pelo organismo biológico, mas também pelo sistema ideológico de conhecimento em cada contexto.

Para Lemke (1997), todas as culturas são redes dinâmicas, complexas, emergentes, são travessias e não estruturas puras. Existe uma zona de turbulência: o novo perturba o estabelecido e o estabelecido influencia o novo, existe um processo de familiarização. Através de regras existentes emergem regras novas, na interatividade. Participamos em "comunidades de prática" (Lave 1997) nas quais nos juntamos aos outros nos seus fazeres ecológicos e nas atividades significativas contextualizadas como um "participante periférico legitimo". Na nossa rotina funcionamos em microecologias, ambientes materiais carregados de significado cultural, agindo e sofrendo ações diretas ou mediadas por ferramentas físico-culturais e sistemas culturais materiais de palavras, signos, e outros valores simbólicos. Nessas atividades, os objetos contribuem para soluções tanto quanto as mentes. Práticas de construção de significado significativas são objetos híbridos, são tanto naturais quanto culturais, fazem parte de ecologias materiais e fazem parte de sistemas culturais de significado. $O$ cérebro não controla o corpo, nem a cognição, ele faz parte de um sistema do corpo-no-ambiente que constrói ordem, significado.

Práticas ou vivências não são apenas performances, não apenas comportamentos, não apenas processos ou operações, mas, sim, ações significativas, ações que têm relações de significado umas com as outras em termos de certo sistema cultural; devemos aprender não apenas o que e 
como atuar, mas também o que a atuação significa para funcionar e ser aceito como membro pleno de uma comunidade de prática. Tanto identidades quanto sujeitos se estendem por trajetórias de vida, construindo continuidades através da participação em eventos distintos e em atividades diferentes. A estrutura básica para a continuidade de indivíduos através dos momentos de interação são seus corpos. Combinamos um organismo e uma persona social para construir a noção híbrida de individuo. Em um modelo de sistema ecossocial, as unidades primárias de análise não são coisas ou pessoas, mas processos e práticas. São os processos e práticas que são interdependentes, ligados, criando propriedades emergentes do sistema auto-organizador.

A corporificação de nossa participação na cultura ou comunidade define os significados que construímos. O modo através do qual conectamos eventos passados e presentes são sempre parcialmente singulares.

O aprendizado é um aspecto de formação de identidade, mas formamos e incompletamente integramos varias identidades para nossas pessoas, e nem toda a atividade, ou prática que aprendemos, nos importa igualmente, ou molda igualmente nossas identidades. A construção de significado, a atividade significativa, caso a chamemos de semiose ou cognição, acontece nesse amplo sistema e não somente no nosso organismo ou cérebro. Corporificamos nosso passado da mesma forma que nosso ambiente corporifica o passado dele (e, portanto, nosso passado coletivo) e, nessa nossa interação, não apenas a memória, mas processos culturais, históricos e sociológicos são renovados e continuados, desviados e modificados. Precisamos estender as redes de aprendizado e escola com nossa vivência, exercendo o direito de narrar nos contextos em que atuamos.

\subsection{NARRATIVAS COMO CONSTRUÇÃO DE SIGNIFICAÇÃO}

Conforme viemos discutindo, vivenciamos a linguagem de modo performativo de corpo, alma e espírito e não é possível desvincularmos essa vivência do nosso contexto cultural. Prosseguiremos a discussão, mostrando como o modo 
narrativo da linguagem atua nessa vivência como processo de ação de construção de significação.

Poderiam as narrativas ser reduzidas a um gênero, como o discurso da lingüística, a ficção da teoria literária, ou ainda relatos populares sem importância? O conceito transdisciplinar de narrativa que abordaremos é o de processo semiótico, de signo, de ação, e não produto escrito, não apenas o discurso da lingüística, nem a ficção da teoria literária, mas processo de construção de significação, de interpretação, de vivência. Narrar é impor uma relação plausível entre elementos inicialmente desconectados, construir sentidos ligando elementos díspares. A seguir, procuraremos abordar algumas características da narrativa aos olhos deste conceito transdisciplinar.

\section{6.a. Pensamento Lógico-Científico e Pensamento Narrativo}

Em uma primeira instância, os dois tipos de pensamento nomeados acima representam abordagens contrárias e díspares de construção de realidade; no entanto, verificaremos a seguir que ambos seguem o mesmo princípio de construção de significação.

Jerome Bruner (1986), a partir da psicologia pós-estruturalista, identifica-os como dois modos de pensamento, de funcionamento cognitivo, que fornecem caminhos para organizarmos a experiência e construirmos a realidade: 0 paradigmático lógico-científico e o narrativo. A aplicação do primeiro leva à teoria, à análise precisa, à prova lógica, ao argumento seguro e à descoberta empírica conduzida pela hipótese racional e, no entanto, a imaginação ou intuição que inicia tal processo é a habilidade de ver conexões formais possíveis antes de poder prová-las de modo formal. O segundo nos conduz a boas estórias, dramas envolventes, relatos históricos convincentes (embora não necessariamente verídicos), cria realidades de acordo com as vicissitudes da intenção humana e é desvalorizada culturalmente. 
Mas explica que, ambos, tanto a matemática quanto a ficção requerem a transformação de intuições em expressões dentro de um sistema simbólico, embora o primeiro analise, não descreve o motivo pelo qual pessoas comuns realizam a extração de sentido de suas experiências; ambos são interpretações, ambos criam/constroem uma verdade; ambos acessam nossa canonicidade, seja ela científica ou plausível culturalmente; ambos são construções sócio-históricas contextualizadas. Ser um cientista requer o aprendizado de culturas e a extração do sentido não-racional que as acompanha.

Narrativa não é apenas gênero literário, mas semiose, pensamento, construção da realidade, o próprio processo de significação, daí a psicologia interessar-se pela construção narrativa da realidade. A estrutura narrativa é inerente à interação na prática social antes de se manifestar como expressão lingüística.

O mesmo Jerome Bruner (2001) esboçou nove modos para compreendermos os caminhos pelos quais a interpretação narrativa dá forma às realidades que cria:

1. Estrutura de Tempo: tempo perceptivo do desenrolar de eventos cruciais

2. Particularidade Genérica: detalhes tornam-se convenção para leitura

3. Ações têm Motivos: valores, crenças, desejos, motivos sociais

4. Composição Hermenêutica: compulsão interpretativa com várias opções

5. Canonicidade: convenções, expectativas socialmente construídas

6. Ambigüidade de Referência: tema sempre aberto à interpretação

7. Centralidade do Problema: perspectivismo não universalismo

8. Negociabilidade Inerente: suspensão da descrença

9. Extensibilidade Histórica: meaning-making : annale, chronique, histoire

Portanto, a perspectiva sócio-construtivista considera narrar uma construção de significado para o narrador e para a comunidade, pois esta é 
fluída, sendo um grupo que compartilha das mesmas crenças durante algum tempo. A visão é de uma narrativa contingente, imprevisível que foge ao controle racional, algo natural que foge à previsibilidade cultural. Incluímos, aqui, o conceito de performatividade de Butler (1990), no qual desempenhamos diversos papéis de acordo com o contexto, pois a identidade é contingente. A performance elimina o referente fora do texto, tudo é interpretação, importa o aqui e agora, estou em constante interação, transformação, em movimento, não imito, nem represento, mas, antes, estou em constante criação, resignificação. Ao mesmo tempo em que nossas narrativas são negociadas com narrativas anteriores, ela é nosso processo de significação, liga elementos contingentes.

\section{6.b. Narrativa como Processo de Ação Social e Cultural}

Reiterando, Klapproth (2004), a partir da lingüística e da antropologia, explica como negociamos nossas construções narrativas com as anteriores, ao ligarmos elementos contingentes, narrar é um ato social, sempre inserido no processo social, a partir de nossas narrativas criamos eventos. O significado de nossas histórias/estórias é criado, negociado e comunicado na interação social. $O$ Ocidente $\mathrm{e}$ o positivismo tratam $\mathrm{o}$ conhecimento como descontextualizado da vida real e acessível a todos, o auge dessa atitude é a world wide web, a Internet. A autora comenta o trabalho de Cazden \& Hymes na Universidade de Harvard, que mostra como o uso de narrativas por alunos na contribuição em discussões em sala de aula é depreciado e desencorajado. Os alunos são encorajados a reprimir e a abandonar o uso de narrativas pessoais, a refrasear e a parafrasear a declaração original com certo nível de abstração, o que causa limitações severas na habilidade dos alunos de se expressarem.

Klapproth (2004) pesquisa a cultura aborígine australiana e expõe que a prática oral de contar histórias/estórias tem um papel decisivo na negociação da identidade pessoal e social e na transmissão de conhecimento cultural, estando ambas intrinsecamente conectadas. Para essa cultura, as histórias/estórias e seus vários significados são possuídas por indivíduos de 
acordo com sua posição no universo social e espiritual. A cultura, como um sistema de signos, precisa ser comunicada para ser vivenciada e requer um contador de histórias/estórias performativo que faça uso do ritmo e do movimento corporal e da respiração, para torná-las mais reais. Os discursos dos indivíduos são inter-relacionados com seu universo físico e espiritual, são o que o indivíduo experimenta como sendo seu mundo e a participação em práticas discursivas torna-se um dos meios mais importantes através do qual uma pessoa expressa sua identidade pessoal e cultural. Canalizamos o fluxo de nossa experiência humana bruta no formato convencional da historia/estória.

Brockmeier \& Harré (2005) sugerem um paradigma alternativo no estudo da narrativa que leve em consideração sua condição particular de um discurso contextualizado e seu caráter aberto e transitório, "trata-se de uma nova abordagem teórica, de um novo gênero de filosofia da ciência". Segundo os autores, a origem do interesse pela narrativa nas ciências humanas parece ser a "descoberta", na década de 1980, de que a forma estória, tanto oral quanto escrita, constitui um parâmetro lingüístico, psicológico, cultural e filosófico fundamental para nossa tentativa de explicar a natureza e as condições de nossa existência (Bakhtin, 1981, 1986; Bauman, 1986; Britton \& Pellegini, 1990; Bruner, 1986, 1990; Mitchel, 1981; Nelson, 1989; Ricouer, 1981, 1984/1985; Sarbin, 1986; Schafer, 1989). Com relação a questões referentes à vida humana, é, sobretudo, através da narrativa, que compreendemos os textos e contextos mais amplos, diferenciados e mais complexos de nossa experiência.

"Se houvesse uma vida "real" que fosse realmente vivida por alguém, como poderíamos saber sobre tal realidade?" Ela certamente não é dada a priori, porque tudo o que se passa em uma vida é também parte dessa mesma vida. Viver é atribuir significado a uma vida; na verdade, o processo de construção de significado pode ser visto como o centro da vida humana. As narrativas são formas inerentes em nosso modo de alcançar conhecimentos que estruturam a experiência do mundo e de nós mesmos. A narrativa deveria ser 
considerada como expressão de um conjunto de instruções e de normas para se realizar uma variedade de práticas comunicativas, para ordenar, dar sentido às experiências, promover conhecimento, apresentar desculpas e justificativas e assim por diante.

Ao invés de conceber narrações como entidades cognitivas, lingüísticas, metalingüísticas ou ontológicas, Brockmeier \& Harré (2005) sugerem considerá-las como modus operandi de práticas específicas de discurso. 0 termo narrativa designa uma variedade de formas inerentes em nossos processos de alcançar conhecimento, de estruturar a ação e de ordenar as experiências, de dar sentido à nossa existência, à nossa vivencia. Para estudar a narrativa, devemos, então, examinar tais práticas discursivas, seus textos culturais e seus contextos. O estudo da narrativa nos convida a repensar a questão da experiência humana, porque funciona como uma estrutura aberta e maleável, que nos permite conceber uma realidade em constante transformação e em constante reconstrução. Isso inclui a opção de dar ordem e coerência às experiências da condição humana fundamentalmente instável, de alterar tal ordem e coerência à medida que nossa experiência - ou os seus significados - se transformam.

Crescemos dentro de um padrão cultural de modelos narrativos. As narrativas operam como formas de mediação extremamente mutáveis entre o indivíduo (e sua realidade específica) e o padrão generalizado da cultura. É através de nossas estórias que construímos a nós mesmos como parte de nosso mundo. Culturas, segundo Geertz (1973), são "redes de símbolos" que tratam a ética, a moral e a estética e dependem da interpretação, não existe uma descrição final da cultura, ela só pode ser entendida parcialmente. Constantemente, destruímos o sistema de opressão alheio em nome do nosso, por uma questão cultural. Laraia (2001) reitera que indivíduos participam de forma diferente em uma mesma cultura, a cultura é dinâmica, tem lógica própria.

As investigações de Vieira (2005) explicam que o tempo encontra na narrativa a sua representação mais clara e exata, a narrativa revela-se como o caráter 
temporal da experiência humana. Explica que, de acordo com Ricouer (1983/1994), não existe simplesmente a representação de ações, pois toda ação tem um sentido ético, uma ação só pode ter como finalidade o bem ou o mal. "O que constitui o objeto da representação é o homem segundo a ética. As qualificações éticas vêm do real. O que procede da imitação ou da representação é a exigência lógica de coerência". "O texto só se torna obra na interação entre texto e receptor", uma teoria da escrita deve ser completada por uma teoria da leitura. No momento da leitura, o sujeito interpõe à narrativa 0 seu próprio horizonte cultural e de vida, o que dá margem a múltiplas interpretações do texto narrativo. Estudar a narrativa significa estudar a forma como os seres humanos vivenciam e representam o tempo. Por outro lado, o estudo da narrativa também envolve o estudo de como o homem vivencia e significa o próprio mundo, a própria vida.

\section{6.c. Narrativas Reais e Narrativas Imaginadas}

Será que nossa vivência do tempo, do mundo e da vida tem um caráter puramente real, ou está carregado daquilo que imaginamos ser a realidade?

Ainda segundo Klapproth (2004), a reiteração do esquema narrativo específico de uma determinada cultura e $\mathrm{o}$ ato de compartilhar esse esquema intersubjetivamente refletem a profunda necessidade humana de ressegurar, mútua e constantemente, que as estruturas de coerência internalizadas correspondem ao que o mundo realmente é. A prática narrativa está no âmago da compreensão de nós mesmos e de nossos mundos constituídos culturalmente, está de tal forma automatizada e solidificada que confundimos as narrativas criadas em nossas mentes com a realidade sólida.

Ao ouvirmos, compartilhamos do mundo da narrativa e do sentimento do narrador, aquele que vê participa da mesma perspectiva que aquele que é visto em uma relação intersubjetiva. Na comunhão narrativa, o envolvimento interativo é produzido pelo som e pelo significado, ritmicamente e miticamente, 
criando-se uma resposta emocional e intelectual de insight, e conexão em nível existencial entre os participantes. O narrador cria um mundo narrado da sua experiência vivida ou imaginada e o momento que compartilham passa a ser outra vivência. $O$ narrador interpreta o que narra e o narravinte interpreta $o$ que ouve, ambos criam, constroem significados.

Ao discutir o papel das ciências, Heidegger (1986) expõe que estas tentam assumir, para si, a tarefa da filosofia de apresentar as ontologias de várias regiões de seres (natureza, história, direito, arte), mas a teoria que desenvolvem tem função cibernética, tecnológica, cujo modelo operacional é o pensamento calculativo e representacional, justificado através de resultados demonstrados aos quais é negado qualquer significado ontológico. Tanto para a existência quanto para o pensamento é preciso que haja uma clareira aberta, para tudo que possa estar presente ou ausente; nesse espaço de possibilidades, a presença e a percepção, o existir e o pensar podem surgir e conviver.

De acordo com a epistemologia, narrativas são formas de saber, de entender o que ocorreu, representações de "eventos reais", mas, para a proposta sob a perspectiva filosófica, que valoriza ontologias diferentes (aquilo que existe, que acreditamos ser real) presentes em mundos construídos discursivamente, estes não são uma simples representação de uma realidade externa e independente, mas mundos interdependentes e co-emergentes do processo cognitivo (Klapproth 2004). Temos uma enorme dificuldade em compreender e perceber o que existe para o outro, a realidade que este constrói a partir de sua ontologia, pois, automaticamente, imaginamos que nosso mundo, nossos valores, aquilo que acreditamos ser a realidade, ou ainda, a realidade que construímos, é a única "verdade".

O conhecimento é visto pelo positivismo como objetivo e como algo que existe independentemente da mente subjetiva que o concebe, conseqüentemente, as práticas educativas que seguem tal linha consideram o conhecimento uma entidade descontextualizada. A questão filosófica entre a dicotomia do "mundo 
real" e "mundo imaginário" é considerada uma noção popular e nossa experiência diária como algo literal, enquanto apenas a imaginação é tida como metafórica. No entanto, todos nossos mundos conceituais, caso considerados reais ou ficcionais, são criados em nossas mentes de acordo com certos padrões cognitivos. Experienciamos continuamente percepções mentais e sensoriais que moldam nossos mundos humanos de significação, que fazem sentido para nós.

\section{6.d. Narrativa como Busca Existencial e o Direito de Narrar}

Diante de tais percepções mentais e sensoriais que moldam nossa significação, selecionamos as que fazem sentido para nossa busca existencial, as que, teoricamente, nos garantem alguma identidade e lutamos pelo direito de narrá-las, pelo direito de significar.

Segundo Usher \& Edwards (1994), a questão é que sonhamos com a presença, com o desejo de conhecermos o mundo através de uma linguagem que represente um mundo transparente e verdadeiro, onde o significado esteja presente ao pensamento sem as distorções da linguagem. Presença significa representação perfeita, onde a linguagem seria - simplesmente - um meio representacional transparente para descrever a natureza do mundo, tornando-o presente, sem se interpor entre o sujeito observador e o mundo, em uma coemergência entre observador e fenômeno. Com a presença, as possibilidades tendenciosas de todo tipo são removidas, pois não há espaço para a decepção negociar - a linguagem/língua meramente representa aquilo que é/existe. Com a presença, o sujeito fica de lado, como um ser autônomo que apenas "enxerga" com um olhar direcionado internamente e externamente, intocado pela forma social.

No entanto, a problemática pós-moderna cria um espaço crítico onde os dualismos - agência/determinismo do sujeito, natureza/cultura, masculino/feminino, racional/vivencial - podem ser desconstruídos e 
reconstruídos. O desejo por um fundamento, ou desfecho, seria negar a amplidão do significado da experiência e a contínua formação e reformulação do sujeito. Historicamente, seres humanos ambíguos posicionam a educação em terreno ambíguo, à medida que buscam e, ao mesmo tempo, rejeitam uma resolução. Não temos uma origem, nem um destino, mas estamos sempre a caminho, nossa autocompreensão é constituída pela inter-relação temporal entre passado, presente e futuro. Assumimos uma responsabilidade pessoal, estabelecendo o diálogo, o engajamento prático e um tipo de auto-referencialidade, de narrativa, talvez nosso velho conhecido livre-arbítrio. Vivemos em uma constante reflexão hermenêutica a cerca da sombra de existirmos, do reconhecimento da falta que energiza nossa busca em direção ao desconhecido.

De acordo com o pensador cristão chinês Nee (1987), nosso vazio existencial é de ordem espiritual, existe uma comunicação espiritual entre seres viventes que acontece subliminarmente, pois, muitas vezes, percebemos o espírito por trás de uma narrativa, utilizamos nossa sensibilidade e, igualmente, nossa interpretação, para percebermos a construção do significado do outro; porém isso não ocorre apenas através das palavras que ouvimos, mas também através da energia que emana do espírito em questão. Escutar as palavras de um homem é nos aproximarmos de conhecer seu espírito. Quando escutamos uma conversa, muitas vezes o assunto em discussão pode distrair-nos dos espíritos em questão, mas nossa percepção nos permite outros contatos e, embora possamos compreender o outro através da nossa interpretação, não percebemos apenas a ação, mas também o espírito, a alma do outro. 0 intelecto e a emoção são insuficientes, a razão pode encontrar-se com a razão, a emoção pode encontrar a emoção, mas existe uma questão mais profunda que é o espírito tocar o espírito. Não devemos preocupar-nos tanto com a palavra, mas com a impressão que é transmitida. A comunicação e a comunhão espiritual vão além do intercâmbio de idéias e de opiniões, pois são as interações de espíritos. Espíritos que interagem formando comunidades de prática. 
Durante uma entrevista, o crítico pós-colonial Bhabha (2001) explica que a globalização, a nacionalização e o novo nacionalismo estão em um profundo estado transicional e tradutório e que a nação sobrevive, hoje, em uma situação complexa e comprometida. Caso se fale em transnacionalismo, pósnacionalismo ou desnacionalização, o importante é percebermos qual parte da nação está sendo reciclada e reiterada, transformada, reaproximada e retraduzida. As sociedades e culturas, a título de negociarem seu futuro, de fazerem ou de marcarem alguma transição, necessitam de um ritual problemático e intricado ao juntar a memória pública, o testamento público, ou o testemunho público, através das problemáticas de indivíduos envolvidos em situações históricas conflitantes. Portanto, ele se declara interessado em compreender o que está envolvido no ato de conceder a alguém o direito de narrar e o porquê desta ser uma questão tão importante, tanto enquanto direito de expressão, quanto direito de enunciação. A noção de quem é o sujeito do direito de narrar não é o individuo que está narrando, mas uma rede de eventos e de enunciações, de construções, de escrituras que constroem a possibilidade de narração. A partir dos grandes movimentos sociais dos nossos tempos - diásporas, refugiados, migrantes - as pessoas e os grupos têm constantemente um modo dividido de ser. Eles podem ser cidadãos políticos em uma determinada cultura e cidadãos culturais em um sentido cosmopolita muito diferente e transnacional. Eles vivenciam essa divisão; mesmo para as pessoas que não são migrantes, se, repentinamente, sua sociedade, ou comunidade, se torna o local onde uma gama enorme de outras pessoas se instala, então a natureza da jurisdição se torna diferente. O próprio chão que eles pisam é renomeado, mesmo se eles nunca se afastaram dele. De repente, há influxos de pessoas com narrativas próprias, histórias próprias, criando uma situação na qual a narrativa de enunciação ganha força e poder específicos. A narrativa deve ser vista como poiesis da prática social e política. Fazer leis, ética, história, ou, até, um evento são parte do direito de narrar.

O que está em jogo é o direito de buscar uma identidade através do ato de narrar, de narrarmos uma vivência, de vivenciarmos uma narrativa, o direito à busca existencial, ao significado da vida. 


\title{
2.7. IDENTIDADE COMO TEIA DE SIGNIFICAÇÃO
}

\author{
"The first duty in life is to be as artificial as possible. \\ What the second duty is no one has as yet discovered."
}

(Oscar Wilde 1998:521)

Viemos demonstrando que atuamos performativamente com nossa vivência de corpo, alma e espírito em determinados contextos sociais e culturais e que, através de narrativas reais, ou imaginadas, construímos nosso processo de significação, de compreensão da nossa existência em busca de alguma identidade.

Seriam as identidades essencialistas, estáveis, imutáveis através das vicissitudes da história? Talvez a fé em um Deus único que rege o universo, com o qual teríamos comunhão espiritual nos conduziria a afirmar que sim; no entanto, após as idiossincrasias que as mitologias e as religiões tanto ocidentais quanto orientais - que não passam de especulações e de construções humanas, de manipulações históricas do divino em nome do poder - criaram ao longo da Antiguidade, da Idade Média e da Modernidade, somos levados a duvidar dessa versão e, desde então, tanto a filosofia, quanto a ciência e a arte têm discutido a questão.

Partimos de premissas falsas e insistimos nelas exaustivamente. Nietzsche declarou, em 1882, que Deus estava morto, mas considerando-se a espécie humana, ainda haverá cavernas por séculos, nas quais a sombra de Deus permanecerá, o abandono da fé em Deus vem acompanhado de um profundo senso de perda emocional, de incompletude, que é uma das características mais notáveis de nosso tempo. Baudrillard (1999) declara que, na ausência de Deus, tudo pode metamorfosear-se livremente e que, inclusive, matamos o mal, fingimos que tudo o que fazemos faz parte do bem: nossa tecnologia e bem-estar provocam o aquecimento global, guerras, fome..., tudo em nome da evolução humana que, teoricamente, é para melhor. Nossa incompletude 
propicia tais metamorfoses em nome de um significado do qual não temos garantia alguma.

\section{7.a. A Crise de Identidade e O Processo de Identificação}

$\mathrm{Na}$ falta de uma identidade fixa vivenciamos uma crise de identidade e percorremos diversos processos de identificação, nos quais a ilusão de ter algo nos satisfaz por um determinado tempo e contexto.

\footnotetext{
“... as velhas identidades, que por tanto tempo estabilizaram 0 mundo social, estão em declínio, fazendo surgir novas identidades e fragmentando o indivíduo moderno, até aqui visto como um sujeito unificado. A assim chamada "crise de identidade" é vista como parte de um processo mais amplo de mudança, que está deslocando as estruturas e processos centrais das sociedades modernas e abalando os quadros de referência que davam aos indivíduos uma ancoragem estável no mundo social."
}

(Hall 1997:7, grifo nosso)

Com o intuito de organizar nossas reflexões, Hall (1997) considera três concepções de identidade, ao longo da história, como tendo proporcionado algum tipo de ancoragem:

1. Sujeito do Iluminismo - apesar de centrado no humano, considerava-o centrado, unificado, dotado de razão, de consciência e de ação, cujo núcleo interior permanecia o mesmo desde o nascimento até a morte;

2. Sujeito Sociológico - ainda dotado de essência interior, mas modificado em interação com valores, sentidos, símbolos sociais e culturais;

3. Sujeito Pós-Moderno - contingente, performativo, plural, móvel, múltiplo, contraditório, formado e transformado pelas representações e pelas interpelações de sistemas sócio-culturais. 
A idéia de uma essência interior foi sendo substituída pelo conceito de performatividade e de identificação. De acordo com seu pensamento, temos identidades contraditórias que deslocam continuamente nossas identificações. Nosso eu-performativo está inserido nas concepções da crítica anti-essencialista étnica, racial e nacional da identidade cultural e política local; a questão de identidade recorre na tentativa de rearticular a relação entre sujeitos e práticas discursivas, entre a política de exclusão e a questão da identificação.

“... à medida que os sistemas de significação e representação cultural se multiplicam, somos confrontados por uma multiplicidade desconcertante e cambiante de identidades possíveis, com cada uma das quais poderíamos nos identificar - ao menos temporariamente.

(Hall 1997:14, grifo nosso)

A identificação, em um sentido comum, é construída a partir do reconhecimento de uma origem, ou de características em comum, ou de ideais em comum, utilizando-se de significados do repertório discursivo e do psicanalítico, estando sujeita ao jogo da diferença. Para a abordagem discursiva, ela é uma construção sempre em processo e, para Freud, a primeira expressão de um elo emocional com o outro. Para Lacan (1988), a subjetividade é estruturada de acordo com o Imaginário (identificações e imagens) e o Simbólico (linguagem e cultura). Aquilo que o ego acha que sabe é uma realidade ilusória, o sujeito da linguagem inserido no contexto social tem uma sensação de continuidade, mas que não passa de uma identificação opressora, nunca é ele mesmo, mas o marido de alguém, o irmão de alguém, o amigo de alguém. A linguagem é performativa e referencial, identifico-me com ela, mas me perco nela como um objeto, ela é uma presença feita pela ausência devido a sua natureza simbólica, funciona através da diferença e da negatividade. Devido a nossa incapacidade em responder a pergunta "quem sou?", somos fundados no Outro, no sistema de significação da linguagem que nos torna inconscientes e opacos para nós mesmos. Seres humanos são essencialmente paradoxais e ambivalentes. 
"Identidade e diferença não são criaturas de um mundo natural ou transcendental, mas do mundo cultural e social", afirma Rubio (2006:35). Independente de discutirmos se nossa indeterminação, se nossa contingência têm origem natural ou cultural, vivenciamos a ilusão de que nossa identidade é unificada, reunida e resolvida, embora estejamos sempre partidos ou divididos, esta é a nossa crise. A autora explica que a crise de identidade proposta por Hall (2001) não se baseia apenas na concepção de sujeito moderno e em seu descentramento, mas passa por diversas rupturas nos discursos do conhecimento moderno, culminando no deslocamento final do sujeito cartesiano. Cinco grandes momentos de ruptura contribuíram para este impacto:

1. O Marxismo, principalmente em Althusser - não há uma essência universal de homem; fazemos a história sob condições dadas.

2. O Inconsciente de Freud - a identidade não é fixa e unificada, mas formada com base em processos psíquicos e simbólicos do inconsciente. Lacan fala em identificação.

3. A Lingüística Estrutural de Saussure - produzimos significados nos posicionando nas regras da língua. Derrida chama nossa atenção para a impossibilidade de fixar um significado, pois este procura um fechamento (identidade), mas é constantemente perturbado (pela diferença).

4. O Poder Disciplinar de Foucault - quanto mais coletiva e organizada a natureza da instituição moderna tardia, maior 0 isolamento, a vigilância e a individualização do sujeito.

5. O Feminismo - questionamento de distinções clássicas como o público e o privado, a família, a sexualidade, o trabalho doméstico...

Se, por um lado, tais rupturas do mundo contemporâneo contribuíram para trazer à tona a crise de identidade, por outro, ela sempre existiu, apenas persistia uma ilusão de realidades estáveis. Hall (1997) explica que as identidades são estratégicas e perspectivistas, estão sujeitas à historicidade radical, em constante processo e transformação. Desde as identidades culturais, nacionais, a globalização, até os processos de migração forçados, ou de livre e 
espontânea vontade, são fenômenos do mundo pós-colonial que, apesar de invocarem uma origem em um passado histórico, na verdade, lidam com questões de utilizar os recursos da história, da linguagem e da cultura; a questão de identidade recorre na tentativa de rearticular a relação entre sujeitos e práticas discursivas, entre a política de exclusão e a questão da identificação.

\section{7.b. A Construção de Identidades Nacionais}

Um dos aspectos realmente interessantes relativos à identidade nacional é o poder que ela tem de dar a ilusão de pertencimento, de que não estamos soltos na vida, nem à deriva, mas que fazemos parte de uma identidade maior e de que, portanto, "certamente" temos alguma identidade. De acordo com Hall (1997), nossas culturas nacionais são nossas principais fontes de identidade cultural. Brasileiros, alemães, suíços, portugueses e africanos não são informações impressas em nossos genes, antes se trata de metáforas, mas temos a ilusão de que elas constituem nossa natureza essencial. Imaginarmos um homem sem nação cria uma fonte de tensão que focaliza o aspecto central da questão do nacionalismo: o fato de acharmos óbvio que um homem deve ter uma nacionalidade assim como tem um corpo. Não nascemos com as identidades nacionais, elas são "formadas e transformadas no interior da representação". Nações são comunidades simbólicas e, portanto, têm poder para gerar sentimentos de identidade e de lealdade.

\footnotetext{
"As culturas nacionais, ao produzir sentidos sobre 'a nação', sentidos com os quais podemos nos identificar, constroem identidades. Esses sentidos estão contidos nas estórias que são contadas sobre a nação, memórias que conectam seu presente com seu passado e imagens que dela são construídas."
}

(Hall 1997:55, grifo nosso) 
Mas, segundo Bourdieu (1996:106), os ritos de instituição, como a identidade nacional, estabelecem hierarquias identitárias, existe uma questão um tanto metafísica por trás da ilusão de termos uma identidade:

\begin{abstract}
"Será que os ritos de instituição, quaisquer que sejam, poderiam exercer o poder que thes cabe...se não fossem capazes de dar ao menos a aparência de um sentido, de uma razão de ser, a esses seres sem razão de ser que são os seres humanos, de lhes dar o sentimento de ter uma função, ou mais simplesmente, uma importância, livrando-os assim da insignificância? O verdadeiro milagre produzido pelos atos de instituição reside sem dúvida no fato de que eles conseguem fazer crer aos indivíduos consagrados que eles possuem uma justificação para existir, ou melhor, que sua existência serve para alguma coisa. Todavia, por uma espécie de maldição, a natureza essencialmente diacrítica, diferencial, distintiva do poder simbólico faz com que o acesso da classe cultivada ao Ser tenha como inevitável contrapartida a queda da classe complementar no Nada ou num Ser Menor."
\end{abstract}

(Bourdieu 1996:106, grifo nosso)

$\mathrm{Na}$ ausência de Deus e do mal, nossa identidade se metamorfoseia livremente, nossas identificações e construções nacionais em torno do tema apenas mascaram nossa indeterminação e nossa contingência, criamos uma teia de significações diante do medo de não encontrarmos significado algum para a nossa existência.

\title{
2.7.c. Identidades Híbridas
}

Criamos uma teia de significação identitária para justificarmos nossa existência e tal processo é possível, segundo Menezes de Souza (2004), porque existe uma fenda entre o significante e o significado, que transforma o texto em "um processo produtivo de significados", onde "várias posições de sujeito ideológicas e historicamente situadas podem ser estabelecidas"; nesses contextos, o significado é construído e o leitor e autor se posicionam. Nossa 
contingência é sempre contextualizada, ancorada no presente efêmero, constituída social, temporal e espacialmente. Construímos nossa identidade "nas fissuras e nas negociações que ligam o interno e o externo, o público e o privado, o psíquico e o político", a cultura passa a ser híbrida, produtiva, dinâmica, aberta, transformacional. Segundo o autor, o movimento tradutório de símbolos culturais em signos traz à tona que "as culturas são construções e as tradições são invenções".

A estratégia de sobrevivência no contexto pós-colonial é permeada pela ironia, por conviver com, pelo menos, dois conjuntos de valores e de verdades desiguais que coexistem simultaneamente, marcados por deslocamentos de espaços e de origens (escravidão e diásporas migratórias), que acabam por forçar a visibilidade do hibridismo em uma releitura da diferença e da resignificação da cultura. Tal estratégia "revela de forma performática (ao mostrar, tornar visível e encenar) o hibridismo que constitui tanto as linguagens do dominante quanto à do subalterno".

Para o crítico pós-colonial Homi Bhabha (1994), somos todos híbridos, toda linguagem é híbrida, toda cultura é híbrida, não no sentido de mestiçagem, mas de coexistência em um terceiro espaço intersticial onde os fundamentos não se sustentam, espaço de indeterminismo, onde as ideologias se colocam e se procuram negar; identidade não é aquilo que se diz ser, mas o que o contexto produz, resignificamos em contextos diferentes aquilo que, no encontro com o outro, fica visível, esta seria a tradução cultural. Identidade é construção, interpretação contextual em fluxo. A ilusão de suspensão do movimento histórico predomina quando interpretamos algo em um determinado contexto, em um determinado momento, de um lócus de enunciação específico, mas toda produção já é interpretação, não dá para detectar o ponto de origem nem a garantia de significação. Não existe clareza, nem transparência na escrita, um discurso claro, racional e transparente é altamente ideológico, esconde sua própria ideologia. A identidade, a agência e a política são contingentes, a ironia é que nada é o que parece ser. $O$ 
indeterminismo não nega a possibilidade de significação, mas é proliferação, tudo é relacional sem ser relativo.

O hibridismo e a ambivalência são conceitos que tentam lidar da melhor maneira possível com a complexidade dos momentos históricos, culturais e literários (Bhabha 2001). Não apenas a língua é complexa ou os conceitos são complexos, mas os problemas que temos é que são muito complexos. É impossível compreender o relacionamento entre o colonizador e o colonizado, que têm vivido muito próximos por cem anos, que têm tido um diálogo apesar das diferenças, sem compreender que o colonizado é e precisou ser, ambivalente em relação ao colonial e vice-versa; a história toda da colonização é sobre o antagonismo e a ambivalência. A liberdade é uma coisa muito difícil. Apenas se você foi oprimido é que você compreende como precisou sobreviver através da ambivalência ou da hibridização da sua cultura. O outro lado seria a afirmação da autenticidade cultural: esta é a minha cultura, foi tirada de mim e eu a quero de volta. A hibridização não trata apenas da mistura de culturas, trata da luta pela autorização ou desautorização de uma determinada cultura.

\section{7.d. Identidade do Imigrante}

Nenhuma cultura costuma ser mais desautorizada que a do imigrante. A situação do imigrante é similar à do exilado, pois ambas favorecem detectarmos, mais facilmente, as configurações múltiplas de identidade causadas pela busca do sentido de pertencimento e de um lugar apropriado no espaço social que sintetize seu percurso cultural. 0 imigrante traz sua identidade deslocada devido ao sofrimento da travessia e ao conflito cultural. Os imigrantes percebem a heterogeneidade, a inexistência da pureza na experiência da imigração. 
Segundo o sociólogo argelino Sayad (1998), radicado na França, a imigração é um "fato social completo" e paradoxal, pois encontramos o "emigrante", aquele que saiu de sua própria sociedade, e o "imigrante", aquele que chegou a uma terra de estranhos, como sendo a mesma e única pessoa. Para Bourdieu, que prefaciou a obra de Sayad, "como Sócrates, o emigrante é atopos, sem lugar, deslocado, inclassificável", incômodo onde chega e incômodo de onde sai, pois, em ambas situações, obriga-nos a repensar os fundamentos de legitimidade de acordo com os quais vivemos:

\begin{abstract}
"Nem cidadão, nem estrangeiro, nem totalmente do lado do Mesmo, nem totalmente do lado do Outro, o 'imigrante" situa-se nesse lugar "bastardo" de que Platão também fala, a fronteira entre o ser e o não ser social. Deslocado, no sentido do incongruente e de importuno, ele suscita o embaraço; e a dificuldade que se experimenta em pensá-lo - até na ciência, que muitas vezes adota, sem sabê-lo, os pressupostos ou as omissões da visão oficial apenas reproduz o embaraço que sua inexistência incômoda cria. Incômodo em todo lugar, e doravante tanto em sua sociedade de origem quanto em sua sociedade receptora, ele obriga a repensar completamente a questão dos fundamentos legítimos da cidadania e da relação entre o Estado e a Nação ou nacionalidade".
\end{abstract}

(Bourdieu in Sayad 1998:11, grifo nosso)

Sayad (1998) explica que o paradoxal é que o imigrante não é "nacional" da ordem nacional em que vive, que o emigrante vive fora da ordem nacional da qual é "nacional" e nos encontramos diante de uma dupla contradição: não sabemos mais se é um estado provisório que prolongamos indefinidamente, ou se, se é um estado mais duradouro, que se vive com um intenso sentimento de provisoriedade. O imigrante passa a ser um homem abstrato, um "corpo-trabalho", um homem "ideal" criado sob a aparência de transferência de mão-de-obra, "pois escapa a todas as determinações concretas, empíricas, histórica e territorialmente, socialmente, politicamente e culturalmente (i.e. nacionalmente) especificadas, pois está liberto de todos os laços (sociais, nacionais, etc.) que o identificariam": 
O autor conclui que os imigrantes são forçados a inventar para si mesmos, ou reinventar outra "nacionalidade" ou "pseudonacionalidade" comum a todos aqueles que só possuem uma identidade alienada por motivos históricos à qual a "assimilação" não pôde por fim.

\begin{abstract}
"No limite agora que a imigração se prolonga durante toda uma vida ativa, viver a vida inteira é o mesmo que ser privado e privarse durante toda a vida do direito mais fundamental, o direito do nacional, o direito de ter direitos, do direito de pertencer a um corpo político, de ter um lugar nele, uma residência, uma verdadeira legitimidade, ou seja, o direito em ultima análise, de poder dar um sentido e uma razão de ser a suas ações, a suas palavras, a sua existência; é não ser habilitado, não poder adquirir os meios para ter uma história, um passado e um futuro e, assim, a possibilidade de dominar essa história."
\end{abstract}

(Sayad 1998:270, grifo nosso)

É importante notarmos, no entanto, que tanto os nacionais quanto os imigrantes podem ser representados como mão de obra e que a complexidade relacionada à crise de identidade não é privilégio apenas do imigrante, embora seja muito mais facilmente detectada neste, devido às circunstâncias de sua condição.

Nossa discussão abordou o fato de construirmos nossa identidade através do processo de ação performativo de narrativas vivenciadas de corpo, alma e espírito em determinados contextos sócio-culturais. Percebemos que a questão do hibridismo, de convivermos com grupos de valores culturais diferentes, está presente em todos nós e é negociada em um terceiro espaço performativo, onde os fundamentos colidem e trazem à tona nossa contingência e nossa indeterminação. Assim como a crise de identidade e o direito de narrar, também o direito de significar, o direito de buscar um significado para nossa existência são mais facilmente detectados e compreendidos na situação do imigrante em busca de uma identidade nacional, embora definitivamente seja uma luta de todos nós. A falta é que propicia essa necessidade de instituirmos uma multiplicidade de paradigmas e uma teia de identificações, na ilusão ou na 
esperança de termos algo, de termos a presença, de alcançarmos nossa língua-franca.

\section{VIVÊNCIAS DA COMUNIDADE PESQUISADA}

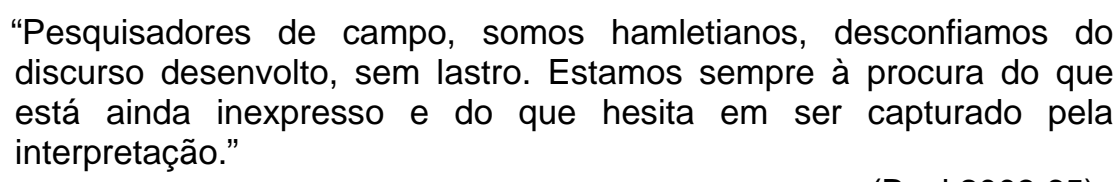
discurso desenvolto, sem lastro. Estamos sempre à procura do que está ainda inexpresso e do que hesita em ser capturado pela interpretação."

(Bosi 2003:65)

Com base nas inquietações teóricas discutidas até então, procuraremos identificar aquilo "que está ainda inexpresso" e "que hesita em ser capturado pela interpretação". Ao nos aproximarmos da comunidade pesquisada sob uma perspectiva do nosso aqui/agora, ouvimos as vozes do passado se desenrolarem através dos conflitos de construção de significados dos contextos em que viviam.

Com Klapproth (2004 em 2.6.b), entendemos que criamos eventos com nossas narrativas, na interação social criamos e negociamos o significado de nossas estórias/histórias. Igualmente, com Brockmeier \& Harré (2005), concluímos que viver é atribuir significado a uma vida e que a narrativa corresponde a uma série de processos de alcançar conhecimento, de estruturar a ação e de ordenar experiências, de dar sentido à nossa existência, à nossa vivência.

Analisaremos, a seguir, algumas narrativas vivenciadas das identidades dos membros da comunidade estudada em documentos escritos e de depoimentos orais, a partir do século XIX, e a repercussão na construção de identidades individuais e nacionais até os dias de hoje; analisaremos seus textos culturais em seus respectivos contextos. Iniciaremos com a pessoa do Senador Vergueiro que foi o grande mentor da imigração de cunho particular para as fazendas cafeeiras do estado de São Paulo a partir de 1846. 


\subsection{Vivência da Grande Narrativa Nacionalista de Inclusão e de Pertencimento}

O documento escrito DE-1 é o Caderno de Memórias n¹- O Senador Vergueiro e a Imigração Européia, publicado pela Sociedade Pró Memória de Limeira, pelos editores José Eduardo Heflinger Junior e Paulo Masuti Levy, em Limeira, Setembro de 1999, com o apoio cultural da Prefeitura Municipal de Limeira, da Secretaria Municipal da Cultura, Turismo e Eventos, de Papel Chamois e Ripasa. Notamos, imediatamente, o apoio de entidades representativas do poder ao direito de narrar essa interpretação da história. Trata-se de um resumo biográfico do Senador Vergueiro a partir de seus três maiores historiadores - Reynaldo Kuntz Busch, Djalma Forjaz e José Sebastião Witter - e da observação da importância de suas experiências pioneiras com imigração, desenvolvidas na Fazenda Ibicaba, como principal fato histórico da origem da cidade de Limeira.

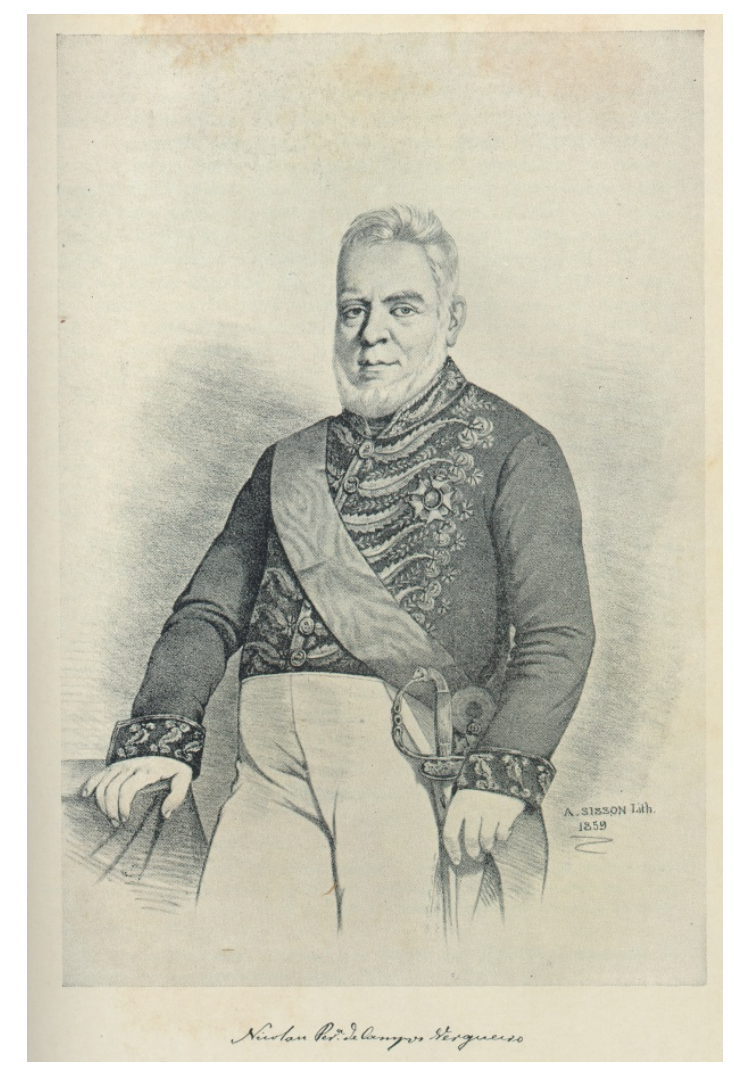

Senador Nicolau de Campos Vergueiro.

Artista: Sisson, Sebastião Augusto. Acervo: Museu Histórico e Pedagógico Major José Levy Sobrinho-Tombo 1332-Limeira. 
Notamos que grandes narrativas nacionalistas têm um maior poder de crédito social, principalmente se estas acontecerem em nome de um ideal positivista de progresso.

A publicação faz alusões ao papel do Senador Vergueiro quando da abdicação de D. Pedro I, em 7 de Abril de 1831, como "o político mais popular do império" que, ao ser solicitado para salvar o trono, escondeu-se para forçar a abdicação e compor a Regência Trina Provisória como representante dos liberais, em 17 de Julho de 1831. A principal medida tomada por essa Regência, que governou o país por três meses, foi convocar os demais parlamentares para que elegessem, em Assembléia Geral, a Regência Trina Permanente. Apesar de manter as estruturas políticas do Império autoritário, a Regência Provisória tinha um caráter liberal e anti-absolutista. Era o início do chamado avanço liberal, que durou até 1837, quando os grupos políticos das províncias alcançaram um maior grau de autonomia.

Como ministro do Império, Vergueiro constrói sua narrativa nacionalista de identidade, dizendo, em seu relatório de 1832, ser contra a colonização estrangeira oficial, financiada pelo governo, que concedia terras brasileiras a estrangeiros:

"A colonização estrangeira por conta do Governo não só é pouco própria para o roteamento das nossas matas, que pedem outros hábitos, como excessivamente dispendiosa; seria, porém, de utilidade incalculável estabelecer colônias de nacionais em lugares ermos, que mais convenha abrir". (Vergueiro in Forjaz 1924:40, grifo nosso)

Nos Anais do Senado, em uma discussão da lei do Orçamento de 1845, consta que: 
"No parlamento combateu a introdução de colonos que não fossem da raça branca, entendia que a mistura de raças é muito nociva. $O$ que convém são colonos europeus". (Forjaz 1924:40, grifo nosso)

O Senador declara seu preconceito, talvez até mesmo, sem ter total consciência das implicações que tal sentimento acarreta. Após ter experimentado o sistema de parceria com colonos portugueses, em 1840 apesar de não ter obtido o sucesso desejado, devido ao seu envolvimento no movimento liberal -, o que restou dessa iniciativa permitiu-Ihe confirmar a praticabilidade da idéia. No Senado, compõe um plano para favorecimento da imigração de cunho particular:

"Em 1845, como senador convicto da necessidade de colonização, ofereceu uma emenda ao Orçamento do Império, que foi aprovada, autorizando o Governo a despender até 200:000\$000 com a importação de colonos. Em 1846 o Governo Imperial dirigiu convites aos governos provinciais para que promovessem a colonização da zona rural responsabilizando-se pelo transporte dos imigrantes. Foi então que o Governo Provincial de São Paulo pôs o problema imigratório nas mãos do autor da lei emendada. $E$ o Dr. Vergueiro reagiu constituindo uma sociedade civil de agricultura e colonização em Limeira e Rio Claro, com seus filhos, e outra em Santos, de natureza mercantil destinada à compra e venda de café, ambas sob a razão social Vergueiro \& Cia., ficando a direção com ele Vergueiro".

(Busch 1967:185, grifo nosso)

Notamos que, em seguida, o senador se beneficia, assumindo o comando sobre o evento da imigração de cunho particular, ao constituir a Vergueiro \& Cia. com seus filhos, ao fundar a Colônia Vergueiro com 423 alemães na fazenda Ibicaba, no interior do Estado de SP, estabelecendo o sistema de parceria com os colonos cujas regras Busch (1967) resume:

"Em 1846 Vergueiro \& Cia. firmaram contrato com o Governo Imperial para realizar a imigração de colonos europeus. E já em 1847 foi fundada no Ibicaba a Colônia Vergueiro, que logo engajou 423 colonos alemães por contrato com obrigações bi-laterais, por um 
sistema de parceria, cujos tópicos principais eram os seguintes: Os colonos deveriam pagar com o trabalho as despesas de transporte até a fazenda. $O$ fazendeiro Ihes adiantaria o que fosse necessário para sua subsistência, enquanto não estivessem em condições de fazê-lo com o ganho do seu trabalho. Sobre o débito, pagariam juros à taxa de $6 \%$. Cada colono receberia a quantidade de cafeeiros que pudesse cultivar, colher e beneficiar, inclusive replantar as falhas. Do produto da venda do café, deduzidas as despesas, bem como da dos cereais, metade era do colono e metade era da firma Vergueiro \& Cia. Eram os colonos obrigados a fazer em comum o trabalho do preparo e beneficiamento do café, além de manter boa conduta na colônia. A firma não podia desobrigar-se do contrato enquanto o colono bem o cumprisse e este poderia retirar-se da fazenda, desde que saldasse seu débito. As dúvidas por ventura advindas seriam resolvidas por árbitros. Os colonos iriam morar em uma como que vila separada dos escravos, cada família em sua casa." (Busch 1967:186, grifo do autor)

Podemos notar que o Senador continua a usar de sua influência para propiciar os meios para seus próprios fins:

"Em 1852, depois de algumas hesitações e em face do êxito do Ibicaba, O Governo da Província fez votar a Lei Provincial de 19 de julho de 1852, que veio coadjuvar o grandioso empreendimento de Vergueiro \& Cia. Permitindo o contrato de 4 de agosto de 1852, renovado em 15 de setembro de 1854, que possibilitou a essa firma prosseguir na sua indispensável e promissora obra de importação de colonos europeus para a constituição de novas colônias em nossa província, logo adotada em Minas, Rio de Janeiro, Espírito Santo e Paraná." (Busch 1967:187, grifo nosso)

Vergueiro, como político liberal munido de seu papel social de elite e liderança empreendedora, na carta de 1853, escreve ao presidente da província, justifica seu sistema de parceria, identificando-se como um estudioso que analisou, cuidadosamente, a problemática e, de forma inovadora, concebeu a identidade nacional com olhos no futuro: 
- "'Eis aqui um relato do próprio Senador sobre o seu sistema de parceria": Reconhecendo como todos, a grande necessidade de trabalhadores que substituíssem os escravos e concorressem para o aumento da população livre, estudei refletidamente os meios de consegui-lo e pondo de parte as teorias conhecidas, concluí que o sistema de parceria era o mais indicado às nossas circunstâncias, por não necessitar tanto de povoar os desertos como o de povoar as terras ocupadas por muitos raros moradores. Apoiados sobre braços escravos que vão faltar, sendo evidente a utilidade deste sistema para o país, principalmente na atualidade não é menos para os colonos que na sua chegada encontrem quem os supra do necessário e lhes forneçam trabalhos sem afrontarem as asperezas do sertão. O pessoal destas colônias é amável por sua natureza. O colono depois de adquirir os meios de estabelecer-se em terras próprias, deixa o lugar vago a quem o substitua e até mesmo emprega colonos, de que já tenho exemplo. (Carta de Vergueiro ao presidente da Província-06/01/1853)". (DE-1:9, grifo nosso)

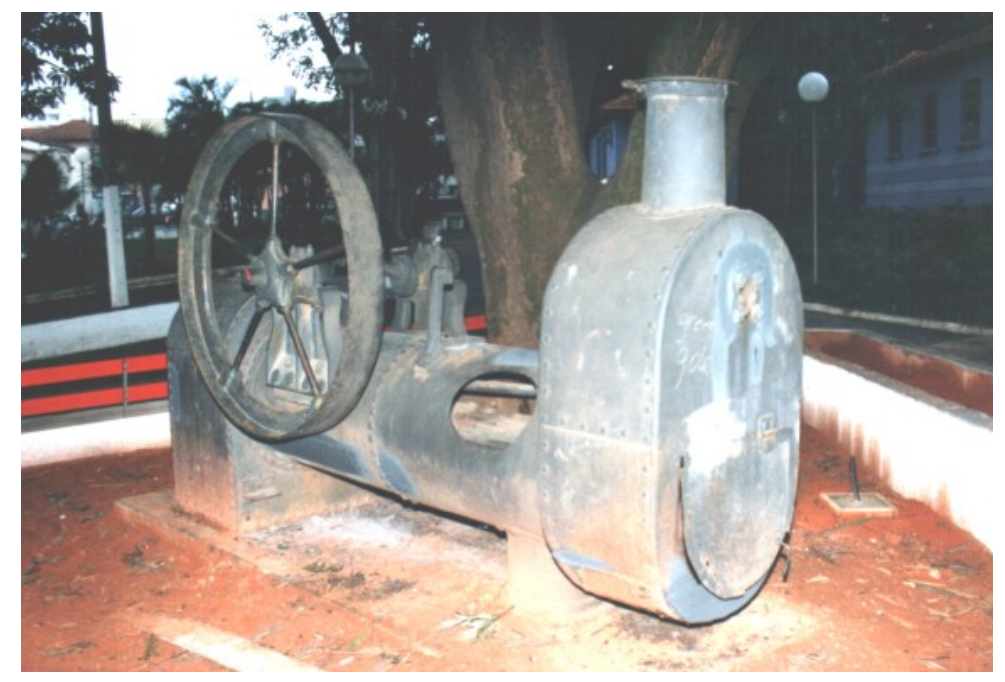

Fazenda Ibicaba: Motor a vapor utilizado pelos Vergueiro, nas máquinas de beneficiar café e em suas oficinas. Foi o primeiro motor do gênero, a ser utilizado no interior de São Paulo. Acervo: Família Levy.

A narrativa de historiadores oficiais confirma o significado de sucesso do grande empreendimento nacional: 
- '“Segundo o historiador Forjaz', Ibicaba foi a Meca da grandeza de São Paulo. Ali se iniciou o movimento de colonização, com o que se pode explicar o progresso paulista, o porquê da privilegiada e vantajosa posição atual em face dos outros estados do Brasil".

(DE-1:1, grifo nosso)

- "O Senador Vergueiro sabia que na imigração repousava os destinos futurosos do Brasil". (DE-1:7, grifo nosso)

- "A prática confirmou suas idéias, de todos os sistemas ensaiados, foi o seu, único a obter resultados".

(DE-1:9)

Segundo Monte Mór (1991:134), "a ideologia liberal positivista projeta a imagem do liberal como a de um homem progressista."

"Os liberais 'integrais' deixam de lado a 'crença no fim do mundo' e, se, de imediato, não deixam de acreditar que o mundo iria se acabar, pelo menos diminuem a ênfase nesta visão para dar espaço à 'idéia de progresso'. Um progresso no sentido capitalista, que apontava para a melhoria de 'status' material do homem, para o qual a atividade se tornava um fim em si mesmo e, portanto, prioritária na esfera econômica-político-social. Aliás, os problemas de ordem política ou social passaram a ser subordinados ao econômico, como sinal de perda de importância na nova organização da sociedade.

(Monte Mór 1991:142, grifo nosso)

Portanto, não parece haver qualquer preocupação com a identidade desses imigrantes que passam a ser uma força-de-trabalho. Conforme discutimos com Sayad (1998 em 2.7.d), eles são homens abstratos, um corpo-trabalho, um homem ideal escondido sob a aparência de mão-de-obra, escapando de especificações culturais, políticas, sociais, históricas, territoriais, empíricas e concretas. Todos concordam com a apolitização da imigração, pois todos têm interesse nas simulações e nas dissimulações envolvidas, ignorando, assim, sua natureza essencialmente política. 
Não cabe ao nosso estudo discutir a grande narrativa da colonização, não obstante notamos que, canonicamente, ela autoriza as classes dominantes a construírem significados socialmente aceitos como verdadeiros, no documento DE-1, as vozes que narram estão carregadas de presença histórica, do direto de significar.

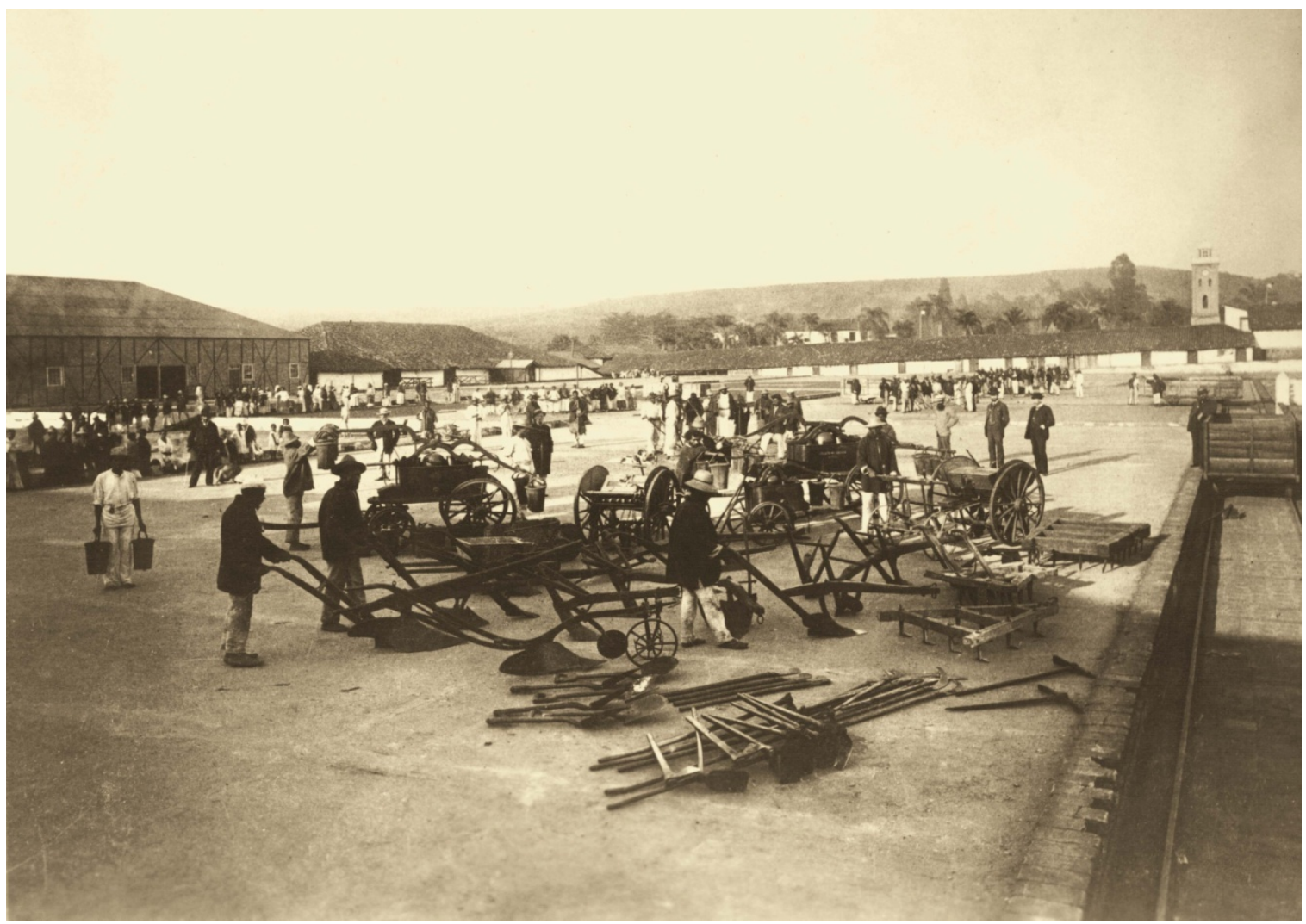

Fazenda Ibicaba: terreiro de café, com colonos e escravos preparando ferramentas. Ao fundo, à esquerda, as duas tulhas para armazenagem do café, um longo edifício de função desconhecida, a casa sede e a torre do relógio. Acervo: Dra. Lotte Köhler - Munique.

Paradoxalmente, existem, no Arquivo do Estado de São Paulo, documentos da Marinha Inglesa - DE-8 que sugerem que o Senador Vergueiro é contrabandista de escravos; podemos verificar que aquilo que se declara, oficialmente, através de um documento, corresponderia a identidades contraditórias. No caso, o poder econômico exercido pela Inglaterra a autoriza a narrar sua versão acerca da identidade de Vergueiro. Segundo o primeiro documento do Livro de Avisos Imperiais, está havendo a notificação de que foi 
apreendido um navio de Vergueiro com 600 escravos e, de acordo com o segundo, os navios de Vergueiro participam de um esquema de corrupção, pois têm permissão para transitar sem serem vistoriados:

- "Aviso de 15 de Fevereiro de 1844, em solução aos Officios d'esta Presidencia sob números 8 e 9 de 28 e 30 de janeiro findo.

$N^{\circ} 3$

$1^{a}$ secsão: Ilmo. Exmo. Senhor = Forão recebidos os dous officios d'esta Presidência sobre números 8 e 9 datados de 28 e 30 de Janeiro próximo passado, nos quaes V. Exa. refere com as informações obtidas das respectivas Auctoridades, e correspondência havida com o Vice Cônsul, e Comandante do BriguesFrolie = de S. M. Britanica, o desembarque que fisera de 600 Africanos, na Fazenda de Vergueiro, O Brigue Português Caçador, apresado no Rio Bertioga por aquelle Cruseiro Inglês, á requisição do Chefe de Policia interino em Santos. Fico inteirado do que V. Exa. assina e comunica e do conteúdo no Officio do Chefe de Policia de 6 do corrente mês, que acompanhou por copia que V. Exa. dirigio na mesma data ao Ministro da Justiça sobre o mesmo assumpto, e foi transmittido a esta Secretaria d'Estado pelo dito Ministro, e em solução ao que V. Exa. Requisita pelo seu Off. No9, cumpre-me significar, para seu governo, que do Artigo $2^{\circ}$ das Instruções dadas aos Crusadores Ingleses e Brasileiros annexas á Convenção adicional ao tratado de 22 de Janeiro de 1815 sobre o commercio de escravos, vê-se _ ? do Brigue, tendo sido apresado nas águas do Império, deve ser remettido ás justiças ordinárias para procederem ao seu julgamento não à Comissão Mixta Brasileira e Inglesa, como muita bem julga V. Exa. _? _ V. Exa. Palácio do Rio de Janeiro em 15 de fevereiro de $1844=$ Ernesto Ferreira França $=$ Sr. Manoel Feliciano de Sousa e Mello. ."

(DE-8, grifo nosso)

- “Aviso de 7 de Janeiro de 1845 do Governo Imperial para a Presidência da Província de São Paulo: 
... de Sua Majestade Britanica n'esta Côrte versando sobre uma licença que diz haver sido concedida por sua Presidência, para que as Barcas de Vapôr pertencentes a Vergueiro, passem a fortaleza de Santos, sem serem visitadas pelas Auctoridades Locaes, a fim de que V. Exa., me informe circunstanciadamente a este respeito. Deos guarde a V. Exa. Palácio do Rio de janeiro em 7 de Janeiro de $1845=$ Ernesto Ferreira França = Sr. Manoel da Fonseca Lima e Silva.

Tradução:

No 101. O abaixo assignado, Enviado Extraordinário e Ministro Plenipotenciário de S. M. Britanica, vê-se obrigado a chamar a attenção do Govêrno Brasileiro sôbre a seguinte comunicação, que acaba de lhe ser feita.

O notório Negociante de escravos Vergueiro obteve recentemente do Presidente da Província de S. Paulo, Manoel da Fonseca Lima e Silva, licença para que os Vapores sob a agencia de Vergueiro passem a Fortaleza de Santos sem serem visitados pelas Auctoridades locaes; tendo d'esta fórma este contrabandista meios mais fáceis para condusir os escravos ao Porto, e d'ali traselos ad libitum; e é de suppor-se que ésta licença tenha por fim este objecto, vendo-se que todos os outros Vapores sem excepção dos de Guerra estão invariavelmente sujeitos á visita. O abaixo assignado pedindo a $\mathrm{V}$. Exa. Que se apresse a tomar informações sôbre esta suspeitosa transacção, e confiando que o Gôverno se esforçará por impedir os resultados illegaes antecipados d'esta, tem a honra de reiterar a $V$. Exa. as expressões de sua perfeita estima e mui distincta consideração = Hamilton Hamilton = Legação Britânica Rio de Janeiro 17 de Dezembro de 1844. P/ V. Exa. Ernesto Ferreira França - está conforme o impedimento do Oficial maior Cândido Manoel de Miranda." (DE-8, grifo nosso)

Esses dois avisos britânicos antecedem O Bill Aberdeen, que foi uma legislação da Grã-Bretanha, de 8 de Agosto de 1845, que proibia o comércio de escravos entre a África e a América. Eles provam que já existia um reconhecimento do governo brasileiro de que a Inglaterra podia patrulhar a 
costa contra os tumbeiros. Após a Revolução Industrial, a Inglaterra passou a contestar a escravidão, interessada em ampliar o mercado consumidor de seus produtos no Brasil e no mundo. A lei que veio a seguir atribuia às embarcações da Royal Navy o direito de apreender quaisquer navios negreiros que, porventura, se dirigissem ao Império do Brasil. O tráfico de escravos era considerado pirataria, embora a lei ferisse o Direito Internacional, sendo que era uma imposição de um país a outros. A sua aplicação criou inúmeros incidentes diplomáticos com o Império Brasileiro: entre 1849 e 1851 foram abordadas e destruídas, pela Royal Navy, cerca de 90 embarcações suspeitas de tráfico para o Brasil, muitas em águas territoriais do país. Esses fatos conduziram à aprovação, no Brasil, da Lei Eusébio de Queirós, em 1850, que extinguia o tráfico de escravos, o trabalho negreiro, dificultando, assim, a obtenção de mão-de-obra para a lavoura.

O Senador Vergueiro constrói os significados de sua identidade a partir de ideais positivistas e liberais que moldam grandes identidades nacionais em nome de um futuro progressista; como membro da elite nacional governista, a partir de sua posição de inclusão e de pertencimento tem seu direito de narrar garantido e suas construções da realidade apoiadas como verdadeiras.

De acordo com os nove modos de Jerome Bruner (2001 em 2.6.a), segundo os quais as narrativas constroem a realidade, podemos perceber como, na comunidade abordada, narrativas de um determinado contexto social, munidas do direito de narrar que a posição social e o poder (Foucault 1990) thes concedem, são consideradas "verdades" e grandes narrativas da história, ao passo que outras, como veremos a seguir, do ponto de vista do subalterno, têm valor menor. No entanto, notamos que, enquanto as primeiras podem ser desmentidas, as ultimas, por sua vez, podem escalar os degraus da verdade social e serem consideradas oficiais. Ambas lidam com a indeterminação e com a contingência, procurando garantir seus paradigmas através da ação emergente e performativa, propiciando a ilusão de que existe "alguma" verdade. 


\subsection{Narrativa do Imigrante como Incômodo e Deslocamento}

Não são apenas os ingleses que discordam da narrativa nacional acerca da identidade do Senador Vergueiro; por um outro lado, verificaremos o ponto de vista de Thomas Davatz, mestre-escola suíço, que chegou em 1855, encarregado de fazer um relatório sobre a situação brasileira para os governos europeus. Ao perceber que viera pelo sonho de uma vida melhor, mas nunca passaria de proletário rural, liderou, em 1856, a rebelião de colonos mais grave da época, que teve - como conseqüência - a proibição da imigração para o Brasil, em especial para a província de São Paulo, pelo governo prussiano (Rescrito de Heydt 1859).

O documento escrito DE-2 - Memórias de um Colono no Brasil (1850) é um livro escrito por Thomas Davatz, reeditado após trinta anos pela Livraria Martins Editora e Editora da Universidade de São Paulo, como parte da Biblioteca Histórica Brasileira, no ano do Sesquicentenário da Independência do Brasil em São Paulo, 1972, com tradução, prefácio e notas de Sérgio Buarque de Holanda. A editora da USP não participa de reedições, mas considerou esse volume, que estava esgotado, indispensável ao estudo de nossa história. Apesar de ser considerado um livro tendencioso, passa a ser, obviamente, aceito por entidades munidas do direito de narrar que apóiam sua republicação. 

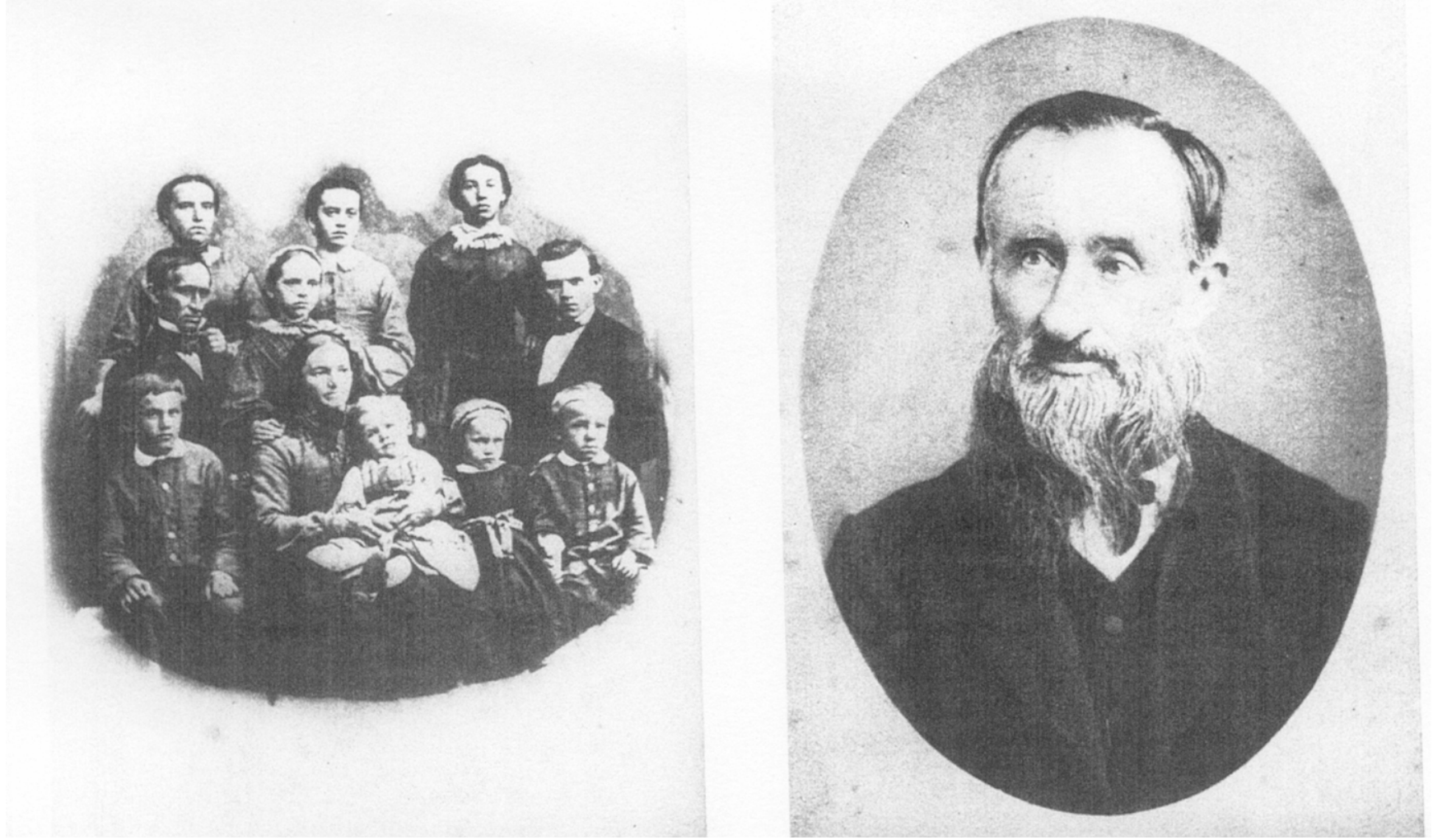

Thomas Davatz e família. Imagem cedida pelo Dr. Rudolf Schallenmüller - USP - Ribeirão Preto. Acervo: Evelyn Hassler.

Ao contrário do Senador Vergueiro e da grande narrativa nacionalista que tem seu direito de narrar sua vivência de identidade garantidos, a partir de uma posição de pertencimento e de inclusão, o autor narra sua versão do ponto de vista do deslocamento, do incômodo de ser estrangeiro, expõe sua construção da realidade sobre as condições brasileiras, o tratamento dado aos colonos e a sublevação. Declara que seus objetivos são amparar os colonos, acalmar a febre de emigrar e esclarecer que há pouco lucro financeiro:

- “... tenho o propósito sagrado e firme de só dizer a verdade. Por um lado, obediente ao principal objetivo desta obra, deveria narrar, tanto quanto possível, todas as injustiças que se praticaram contra pobres seres humanos e ao fazê-lo exponho-me ao risco de que alguém, no Brasil e talvez mesmo em certos lugares da Europa, procure desautorizar-me." (DE-2:4, grifo nosso) 
Para Davatz, existe apenas uma verdade e que enquanto uns estão do lado dela, outros provavelmente mentem; demonstra consciência do poder de narrar exercido pelas autoridades, mas não percebe que existem várias verdades socialmente construídas a partir de pontos-de-vista e de contextos diferentes. Ele expõe a identidade estratégica que passaram a vivenciar no encontro de culturas, a partir da perspectiva de sua posição incômoda no contexto:

- "conhecíamo-nos não tanto na qualidade de suíços, de alemães, de turíngios, de holstenianos, como sobretudo na de colonos oprimidos do Brasil. Qual o homem verdadeiramente amigo de seus semelhantes, capaz de admitir intimamente que alguns sejam esquecidos e desamparados enquanto outros são eventualmente favorecidos pela fortuna".

(DE-2:5, grifo nosso)

Notamos que, na posição de colonos oprimidos, as várias identidades podem passar a ilusão de uma identidade única, dependendo do contexto. Conforme vimos com Sayad (1998 em 2.7.d), até mesmo o paradoxo presente em todo imigrante/emigrante deixa de existir, pois estes são obrigados a reinventar outra nacionalidade, ou pseudonacionalidade, comum a todos que só possuem uma nacionalidade alienada por motivos históricos, à qual a assimilação não pode por fim.

Podemos notar, também, que a ideologia liberal positivista concede uma liberdade relativa, segundo Monte Mór (1991) a liberdade de escolha era de acordo com possibilidades pré-existentes, ou seja, o contexto sócio-histórico prédefine as opções:

"A liberdade passa a ser a liberdade de escolha de algo já existente (quase uma imposição), sem que anteriormente seja dada a opção da verdade na qual se acredita. Impostamente, a verdade adquire a semelhança de "mercadoria" exposta; a verdade é o que está exposto ao indivíduo; dentro do que lhe é exposto é que ele 
deveria fazer sua escolha. Não haveria, portanto, a oportunidade para que o indivíduo refletisse se seria aquela a verdade na qual ele acreditava, se era aquela a opção que ele faria.

(Monte Mór 1991:144, grifo nosso)

A nota do professor Rubens Borba de Moraes, um dos mentores da republicação do livro, explica que a história da imigração em SP precisa ser refeita, confirma o desmerecimento dado à narrativa no discurso científico conforme discutimos com Jerome Bruner (1986 em 2.6.a), mas reitera o valor desta como documento construído em seu determinado contexto:

- "A história da imigração em São Paulo está toda ela por fazer. O que se tem escrito até agora não passa de narração. Não se estudou ainda o aspecto social e econômico... enfim uma verdadeira história social como é necessário que seja feita para não se tornar uma narrativa digna somente de cinema (...) não é, portanto um livro imparcial: é o libelo acusatório de um colono contra o patrão. Mas talvez por isso seja interessante. (...) Não é somente a narração dramática da revolta desses pobres colonos contra um fazendeiro poderoso e respeitado que nos interessa como documento humano, mas sobretudo, o estudo das condições de trabalho na fazenda como documento de história econômico-social." (DE-2:V, grifo nosso)

O tradutor Sérgio Buarque de Holanda, ao escrever o prefácio da publicação cujo trecho transcrevemos abaixo, concorda com Derrida (1978 em 2.3), quanto ao excessivo valor dado à escrita e à necessidade de desconstruirmos para compreendermos vivências diferentes de acontecimentos em comum, para percebermos as várias vozes de Bakhtin:

- "Para estudar o passado de um povo, de uma instituição, de uma classe, não basta aceitar ao pé da letra tudo quanto nos deixou a simples tradição escrita. É preciso fazer falar a multidão imensa dos figurantes mudos que enchem o panorama da história e são 
muitas vezes mais interessantes e mais importantes do que os outros, os que apenas escrevem a história. Exercício difícil e cheio de seduções perigosas onde faltam pontos de apoio seguros, levará facilmente a aceitar seus resultados como a única verdade digna de respeito. Seria difícil, por exemplo, imaginar-se a escravidão no Brasil descrita do ponto de vista de suas vítimas, se estas tivessem voz articulada, e não do ponto de vista dos escravocratas, dos governos, dos abolicionistas... Mais difícil, porém, seria acreditar que para muitos essa descrição, se existisse, não passaria a valer por si, constituindo matéria prima de apologias ou invectivas. Para o caso das colônias de parceria...temos um depoimento dessa natureza...é inútil insistir muito na intenção polêmica em que foi composto ... Livro de partido, mas também de boa fé, ele é a expressão e o prolongamento da vida de um pobre colono perdido num mundo hostil às suas aspirações." $\quad$ (DE-2:XLIV, grifo nosso)

Fazer falar figurantes mudos seria arriscar tal fala a ser classificada de ficção, como se a fronteira entre o que vivemos de fato e o que vivemos ficcionalmente não fosse tênue por princípio, conforme Klapproth (2004 em 2.6.c). O fato de existir o livro de Davatz, com sua versão polêmica sobre as colônias de parceria, com a narrativa de sua vivência dos acontecimentos, que foi aceito como expressão da verdade pelos governos europeus e que, por sua vez, proibiram a imigração para o Brasil, prova o quanto é, também, tênue a fronteira entre verdades instituídas historicamente e verdades narradas.

O Senador Vergueiro acreditava em seu empreendimento, expressando valores liberais positivistas da sua comunidade e da comunidade internacional, não tinha idéia dos conflitos culturais que estava criando, até que o colono suíço Davatz, mestre-escola, pessoa culta, encarregada de descrever a situação para a comunidade européia, ao sofrer o choque que toda imigração propicia, ao perceber que a realidade não é transparente, trouxe alguns problemas à tona. Aquilo que é prioridade e certeza para uns, em outra cultura passa a ser duvidoso; para Davatz, que veio pelo sonho de "Fazer a 
América", era difícil não poder garantir sua identidade, era chocante verificar que, na verdade, poderia estar sendo um escravo branco do, segundo ele, ganancioso escravocrata Senador Vergueiro:

- "Os colonos que emigram, recebendo dinheiro adiantado tornam-se, pois, desde o começo, uma simples propriedade de Vergueiro \& Cia. E em virtude do espírito de ganância, para não dizer mais, que anima numerosos senhores de escravos, e também da ausência de direitos em que costumam viver esses colonos na província de São Paulo, só Ihes resta conformarem-se com a idéia de que são tratados como simples mercadorias, ou como escravos."

$(D E-2: 37)$

O contexto europeu em torno de 1815 (fim do domínio napoleônico) a 1848 (reação liberal) do qual esses migrantes saíram foi marcado por profundas transformações industriais espelhadas no modelo britânico, transformações lentas e graduais na organização econômica dos estados alemães, que repercutiram no campesinato e na população urbana igualmente:

\footnotetext{
"As conseqüências para a população urbana, que vivia do artesanato, foram as piores. Impossibilitados de concorrer diretamente com as modernas máquinas que pouco a pouco, substituíam sua força de trabalho, muitos artesãos sentiram na pele a ruína financeira e o desemprego. Tendo como alternativa a emigração, partiam em grandes grupos rumo às Américas do Sul e do Norte, numa tentativa desesperada de não engrossar as fileiras do proletariado artesão, que rapidamente surgiam nos centros urbanos alemães".
}

(Siriani 2003:29, grifo nosso)

\begin{abstract}
"A pressão sobre o campesinato alemão também foi um elemento de desestabilização social no período. Acostumados a ser proprietários, por menos abastados que fossem, não eram capazes de compreender a espoliação que Ihes impuseram os senhores do campo, privando-os do bem mais sagrado para um camponês: a terra. Não compreendiam o trabalho assalariado em terras que haviam sido suas. Essa situação acabou por
\end{abstract}


desencadear uma gigantesca onda emigratória para os Estados

Unidos da América e para o Brasil, que perdurou, com maior ou menor intensidade, até a década de 1880".

(Siriani 2003:34, grifo nosso)

Igualmente, no século XIX, milhares de suíços deixaram sua pátria em busca de sobrevivência. O crescimento populacional, o clima frio e a topografia montanhosa não permitiam trabalhar a terra de forma a colher bens agrícolas em quantidade e com qualidade satisfatórias para alimentar e ocupar a população. A Suíça da época de 1840 é politicamente instável. Duas visões de mundo se afrontam sem piedade. De um lado, há os conservadores, ardentes defensores da soberania dos cantões e das prerrogativas das Igrejas. De outro lado, os liberais e os radicais, partidários de um poder central forte, de uma economia aberta e da igualdade de direito de voto universal (principalmente para os radicais) e da liberdade de imprensa.

Conseqüentemente, os imigrantes que aqui chegaram vieram cheios de ilusões, também acreditavam nos ideais progressistas de sucesso, apesar de decepcionados em seus países de origem, não estavam preparados para o choque cultural de que seriam vítimas. Na experiência do deslocamento não há volta; por outro lado, nem sempre os que aqui chegaram estavam na sua melhor forma:

"Quando estudei os mapas da colônia de lbicaba e observei a origem dos imigrantes, a sua religião, as datas de seus nascimentos, encontrei dados que ajudaram a explicar suas dificuldades iniciais. A própria origem condicionou-os a usos e costumes totalmente diversos do Brasil, o que já os colocou em face de um problema de relacionamento humano bastante difícil. Acrescente-se o fator língua e veremos quanto mais difícil se tornou esse relacionamento. A religião católica foi outro entrave. Isto criou condições desfavoráveis para aqueles que não eram católicos, o que vale dizer, a maioria. As datas de seus nascimentos são outro fator ponderável. Nas relações da família, encontramos dados que nos revelam ser esses chefes de grupo familiar homens já velhos, o que fatalmente dificultou-Ihes o entendimento da vida brasileira 
e os tornou mais apegados às tradições e às lembranças da

pátria distante". (Witter 1986:33, grifo nosso)

Aqueles que aqui chegaram eram muitas vezes velhos e outros indesejáveis em seu país de origem, por serem fisicamente incapazes ou de baixo nível moral; seduzidos pela propaganda de José Vergueiro, filho do senador, e instigados pelos seus governadores, alimentavam a esperança de uma vida melhor:

“... José Vergueiro voltou sua atenção para a Suíça, tão densamente povoada, passando a fazer, por intermédio de agentes, grande propaganda de seu sistema, no que, infelizmente, foi bem sucedido. Demonstrou-se às comunas de vários cantões que esta era a oportunidade única de se livrarem da população pobre e infeliz, bastando para tal que adiantassem o dinheiro das passagens dos imigrantes, o qual Ihes seria reembolsado pela firma Vergueiro e Companhia, com os fundos obtidos com o trabalho dos ditos imigrantes nas fazendas. Muitas comunas aceitaram de bom grado a proposta aparecendo logo grande numero de famílias que se apressaram em candidatar-se, pois viviam na mais negra miséria e alimentavam a esperança de melhorar a sorte alémmar. Algumas comunas, porém, excederam as medidas de justiça e da decência que lhes cumpria observar com seus compatrícios, aproveitando-se de tão rara oportunidade para fazerem uma limpeza em regra no seio da própria população. Incluíram nas lista dos imigrantes alguns indivíduos fisicamente incapazes ou de baixo nível moral, que um dia lhes haveriam de pesar nos cofres públicos ou serem internados em asilos. Esses indivíduos eram alistados como fazendo parte de tal ou qual família e, por vezes as próprias autoridades forçavam as famílias a incorporar esses pobres miseráveis em seu conjunto, sob ameaça de não cederem o adiantamento necessário para a viagem. Tratava-se na maior parte dos casos, de indivíduos incapazes ou avessos ao trabalho, castigados alguns de graves defeitos físicos. Parece que nem as comunas, nem os próprios imigrantes, chegaram a perceber o alcance do artigo $\mathrm{V}$ dos contratos" (Tschudi apud Witter 1982:53, grifo nosso) 
Davatz descreve cuidadosamente os conflitos e os problemas de adaptação física, biológica e cultural dos imigrantes que aqui chegaram, em um extenso capítulo denominado "Esclarecimentos Prévios e Indispensáveis Acerca de Certas Condições Brasileiras", onde narra o estranhamento com a natureza local vivenciado pelo estrangeiro:

- "Quanto ao calor que reina durante o verão, o que pude observar na fazenda Ibicaba é que, com bom tempo, a temperatura regula ser, pela manhã, de 15 a $16^{\circ}$ (escala Reaumur=18-20') no termômetro com escala de $80^{\circ}$; durante o dia (duas e meia a três horas da tarde), de 24 a $27^{\circ}$; ao sol, de $40-43^{\circ}$ e à noite, de $21-23^{\circ}$. Nos dias chuvosos, porém, chega quanto muito aos $17-20^{\circ}$. Trata-se assim de um calor que pode ocorrer perfeitamente entre nós, embora os raios solares tenham lá um efeito bem diverso. Quem queira fugir ao risco de uma insolação ou de coisas peores, não fique muito tempo ao sol de cabeça descoberta. A terra se aquece por tal forma sob a influência dos raios solares, que seu contato é insuportável mesmo aos que tem o hábito de andar descalço. Não é raro que as solas de sapatos se desprendam, chegando a queimar-se junto aos pregos e assim a desprender-se à força do calor. Não fosse o ar muito temperado pela própria umidade, intensa e constante, e o mercúrio subiria ainda mais. No entanto aqueles que vêm ao país em época de frio (junho, julho e agosto) ou que nele já viveram algum tempo, suportam tão facilmente essa temperatura quanto os suíços suportam as dos seus vales." (DE-2:7, grifo nosso)

- “...os colonos recém-vindos, fatigados e enfraquecidos por uma penosa viagem, e em contato com um clima inteiramente diferente e desconhecido, obrigados a uma alimentação de difícil digestão, ...sejam vítimas freqüentes das moléstias." (DE-2:27, grifo nosso) 
O mestre escola suíço reconhece que, apesar de todos choques e conflitos existentes em um primeiro impacto, relativos ao clima ou à alimentação, que, muitas vezes, causam moléstias, é possível adaptar-se ao clima brasileiro tanto quanto ao suíço.

Discutimos com Varela (1991 em 2.4) que a maneira como interagimos com o mundo e o conhecimento que temos dele depende da vivência corporificada, que não pode ser separada de nossos corpos, de nossa linguagem, de nossas histórias sociais, que o conhecimento acontece via uma ação corpórea, via nossa performance, atuação no mundo. Daí, um conflito em um primeiro impacto, que transtorna a pessoa, devido a sua performance e história social anterior, mas ainda a adaptação provém da mesma ação corpórea em um novo contexto. A interatividade entre o novo e o velho, nessa mesma pessoa e nesse novo contexto, propicia uma importante troca performativa de experiências e de conhecimentos culturais diferentes.

Por exemplo, Davatz não se conforma com a ignorância desta cultura que não sabe tirar proveito de suas riquezas naturais, pelo menos não da mesma forma com que espera se deparar; para todos nós, o outro é sempre ignorante, não percebemos que, simplesmente, a vivência do outro é e pode ser diferente:

- “Não vi muitos carneiros no Brasil....ninguém trata deles e ninguém sabe tosquiá-los e ainda que o soubessem faltariam os meios para $o$ preparo da lã. A pele ressecada e vestida de espessa lã é estendida sobre a sela dos cavalos, proporcionando ao cavaleiro montaria cômoda e agradável. É o único proveito que nesse país sabem tirar da lã."

(DE-2:33, grifo nosso)

- "Se os colonos dispusessem de mais liberdade, se tivessem seu próprio pedaço de terra, então nos lugares onde a libra brasileira de manteiga 
fosse vendida ao preço de 1,60 e 1,80 francos e um bom queijo a 2,30 e 2,80 francos, poderiam sem dúvida organizar magníficos estabelecimentos de criação de laticínios. O leite seria bom e a raça do gado seria melhorada e bem domesticada. Nas condições, porém, em que se pratica a colonização até aqui, nada disso é possível. Em certas colônias os trabalhadores nem sequer tinham meios pra possuir uma vaca."

(DE-2:33, grifo nosso)

- "Assim, por exemplo, enumeravam-se as coisas diversas incluídas nas listas de fornecimentos aos colonos, falavam-se nos roçados e nas bonitas casas que estes recebem, e também nas vacas, nos porcos, nas galinhas, mas sem notar o quanto custam, em que condições e de que modo são fornecidos os terrenos de plantios e habitações, qual o estado em que são entregues, quais os produtos que se obtêm, e de que qualidade são, a que ponto chega a falta de leite, de manteiga, de queijo, de ovos, não obstante as vacas e as galinhas..." (DE-2:91, grifo nosso)

Menezes de Souza nos indica o caminho de Bakhtin e de Bhabha para compreendermos o que acontece quando povos, culturas e histórias diferentes, marcados por deslocamentos, são obrigados a conviver em um mesmo espaço: a cultura passa a ser um processo tradutório de constante resignificação, enquanto estratégia de sobrevivência:

"Ao analisar os discursos coloniais e pós-coloniais, marcados por deslocamentos (espaciais/geográficos, temporais/históricos, lingüísticos, etc.), que fazem com que povos, culturas e histórias díspares tenham que conviver e habitar os mesmos espaços, Bhabha (1994), também influenciado pela obra de Bakhtin, propõe a seguinte noção de cultura como algo híbrido e emergente em meio de contextos que ecoam a heteroglossia de Bakhtin: "[...] o conceito de cultura para além de objets d'art ou alem da canonização da 'idéia' de 
estética, para lidar com a cultura como uma produção desigual e incompleta de significação e valor, muitas vezes compostas por demandas e praticas incomensuráveis, produzidas no ato de sobrevivência social" (1994:172). Tal visão de cultura enquanto estratégia de sobrevivência enfatiza o aspecto tradutório da cultura como um processo incessante de construção de significação no âmbito da circulação de experiências, linguagens e símbolos diversos."

(Menezes de Souza 2006:15, grifo nosso)

No novo contexto cultural, as reclamações dos colonos eram:

"contra a falta de exato cumprimento de cláusulas do contrato, envolvendo principalmente diferenças na medição entre o café colhido e o vendido, cobrança de aluguel de casa e de juros de débitos garantidos pelas municipalidades suíças a que pertenciam, e preços mais elevados nos gêneros fornecidos pela Fazenda em comparação com os correntes no comércio de Limeira e Rio Claro. Davatz, formulou minuciosa denuncia ao Cônsul suíço do Rio de Janeiro e solicitou providências de altas autoridades brasileiras." (Busch 1967:190, grifo nosso)

Ao sentir-se injustiçado, Davatz sabe a que autoridades recorrer para defender seus direitos, não age irracionalmente, procura obter o direito de narrar reconhecido pelas autoridades suíças e brasileiras. Ao consegui-lo, continua a manter a calma, mas a reação dos patrões quase causa uma rebelião armada que o próprio Davatz achou por bem conter:

"No dia 24 de dezembro de 1857, o líder T. Davatz foi convidado a comparecer na sede da fazenda, perante o Senador, seus filhos, José e Luiz, o administrador Jonas e o médico Dr. Gattiker, para expor as reclamações dos colonos. Fê-lo com serenidade, confessando que esperava uma sindicância de altas autoridades em presença do Cônsul da Suíça para comprovar as razões que assistiam aos colonos. Houve exaltação por parte do Senador, que acusou Davatz de fomentar rebelião. 


\begin{abstract}
Enquanto este sustentava com calma as reclamações dos colonos, os Vergueiros gritavam e acusavam o mestre-escola de revolucionário. A intervenção moderadora do médico permitiu que Davatz se retirasse. Mas os colonos, que foram informados por dois "escutas", organizaram-se com armas improvisadas, prontos para acorrer em defesa de seu líder. Felizmente o próprio Davatz voltou à colônia e pediu calma a seus companheiros." $\quad$ (Busch 1967:191, grifo nosso)
\end{abstract}

Enfim, podem ser verificados, nos anexos do livro de Davatz, documentos relativos à sua função como relator para a comunidade européia, assim como 18 parágrafos relacionando queixas dos colonos. O mestre-escola vinha de um contexto europeu, onde se configuravam ideais democráticos, o que justifica sua construção da realidade. No final do século XVIII, a Suíça era uma confederação de repúblicas independentes espalhadas, sendo que algumas eram apenas comunas rurais, outras oligarquias comerciais e outras aristocracias proprietárias de terras. Desde 1848, tornou-se um único país; um estado federal em 1874. Segundo Garcia (2004:6), a Suíça começou a utilizar o referendo em 1848 e a constituição dizia que toda decisão nacional importante deveria ser submetida ao voto popular.

Em contrapartida, nos documentos inéditos anexos ao livro de Davatz, em carta do Comendador José Vergueiro, filho do senador e sócio da Vergueiro \& Cia., ao conselheiro Nabuco de Araújo, percebemos como interpretações diferentes de um mesmo acontecimento, quando munidas de maior poder narrativo, podem eventualmente mudar completamente a história, caso se resolva acreditar nelas, não importando quem gritou e quem tentou manter um diálogo civilizado:

- "Seus fins tem sido revelados em parte, apregoam princípios os mais subversivos, declaram que tem desatendido a comissão enviada pelo Governo Providencial, e que atenderiam essa do cônsul e enviado suíço somente para dar uma cor desculpável e legal a seus atos, porém que sejam quais forem as deliberações dessa Comissão, eles levantar-se- 
ão, apelarão para as armas, e assenhorear-se-ão de toda a Província. Para isso estão unidos e continuam a unirem-se cada vez mais, procurando petrechos de munição de guerra por todos os lados, e por todas as formas até sujeitam-se para as alcançar: Davatz seu chefe é homem astucioso, de suma atividade, sangue frio, e de educação jesuítica. (...) Minha opinião é, - que o Governo Imperial faça expedir dessa Corte com segredo um Batalhão de linha com brevidade possível se apresente neste distrito, desarme as colônias todas, que cada vez vão se tornando mais fortes, prenda os cabeças, e meta-os em Processo..."

A história confirma que os de maior poder, como José Vergueiro, conseguem que se acredite na sua versão dos fatos, mas, felizmente, o suíço Davatz também obteve resposta às suas reivindicações e foi um dos poucos a retornar ao país de origem. Embora ele tenha retornado a seu espaço físico anterior, a experiência do deslocamento não tem volta, no sentido de não podermos apagar a vivência de valores culturais conflitantes:

\footnotetext{
"De São Paulo foi mandado à Limeira um contingente de $\mathbf{3 0}$ soldados de linha para agir se necessário... mas tudo passou até que um representante do senhor Cônsul da Suíça esteve no Ibicaba ouvindo as duas partes. Igualmente, o Governo Imperial mandou o jurista Dr. Tavares Bastos sindicar os fatos, resultando na saída de Davatz e sua família para o Rio de Janeiro e depois seu regresso à Suíça, onde apresentou minucioso relatório de todas as reclamações e ocorrências havidas ao Governo, as quais foram publicadas sob o título de "Memórias de um colono no Brasil", obra traduzida depois para o francês e muito lida na Europa." (Busch 1967:191, grifo nosso)
}

Podemos notar que as interpretações de José Vergueiro têm conseqüências de caráter um tanto militar e bélico, mas, de fato, o contexto vivido por ele, na sua juventude, justifica sua construção da realidade, sua verdade particular: 
"O Sr. José (chefe da casa de Santos) freqüentou a escola militar da Prússia, e chegou ao posto de $1^{\circ}$ logar-tenente do $36^{\circ}$ regimento de infantaria prussiana durante as luctas entre Bélgica e Hollanda."

(Forjaz 1924:46, grifo nosso)

Novamente recorremos aos valores liberais positivistas que circulavam no Brasil da época para compreendermos certas posturas radicais:

\begin{abstract}
"A melhoria dos órgãos particulares aconteceria como decorrência da evolução da estrutura social como um todo, e esta evolução levaria ao progresso social desejado. Contudo, neste conceito de sociedade na qual o homem não existe como individuo e sim como membro de um grupo, fala-se mais em deveres do que em direitos do cidadão. Esse tipo de consciência - que é coletiva, pois nela não há lugar para a liberdade de consciência de cada um - contava politicamente, com um alto grau de solidariedade. Nesta moral advinda do conceito de "fraternidade universal", o altruísmo como conceito de solidariedade estava, na realidade, imbuído de despotismo. Um exemplo disso está no fato de ele sempre dar maior ênfase aos deveres do indivíduo, do que a seus direitos. È comum que os homens até desconheçam seus direitos, dentro deste espírito altruísta."
\end{abstract}

(Monte Mór 1991:147, grifo nosso)

Discutimos a questão de narrativas reais e de narrativas imaginadas com Klapproth (2004 em 2.6.c) e percebemos a profunda necessidade humana de ressegurar e de reiterar o esquema narrativo de uma determinada cultura, para assegurar que as estruturas de coerência internalizadas correspondam ao que o mundo realmente é, sendo que ela está de tal forma automatizada e solidificada que confundimos as narrativas criadas em nossas mentes com a realidade sólida. O narrador interpreta o que narra e, igualmente, o narravinte interpreta o que ouve ou lê, sendo que ambos constroem significados.

Ao escrever sua versão sobre a realidade em torno da época da imigração, o colono Davatz constrói a verdade a partir de seu lócus de enunciação, com uma postura muito mais ética, crítica e realista, onde os detalhes se tornam 
convenção, denuncia a violação e o controle de correspondência, evidencia a supressão do direito de narrar do subalterno:

- "Assim é que certo colono, homem íntegro e sincero, chegou a declararme, conforme já referi de passagem: - 'Arrependo-me por quantos cabelos tenho na cabeça, do dia em que me decidi a emigrar, mas não posso confessá-lo. O Sr. X. predisse o que me sucederia. Em vez de dar crédito às suas palavras preferi confiar nas boas notícias que me chegavam e o resultado é que não poderei, já agora, declarar-lhe que estava errado. Limito-me a dizer como vou passando (e graças à sua situação especial vai passando bem), e silencio sobre o resto'. O medo de vinganças ou as expectativas de melhor tratamento conduzem também muitas pessoas a fornecer boas notícias e mesmo bons testemunhos.

(DE-2:91, grifo nosso)

- "Em suma, as cartas de pessoas consideradas perigosas são cuidadosamente controladas, a correspondência violada, procurase suprimir meticulosamente as descrições exatas. Eu próprio, depois de escrever um relato tanto quanto possível fiel, tive minha correspondência sujeita a censura (censura policial, disse-me o diretor) e recebi mesmo uma carta com o envelope aberto e outra intacta por fora, mas rasgada e amarrotada por dentro." (DE-2:95, grifo nosso)

- "Para oferecer mais uma prova do que afirmo direi que um antigo colono que escrevera uma carta verídica recebeu por esse motivo, tempos após, uma repreensão, que o levou a ditar outra carta, esta contendo elogiosas referências ao regime da fazenda. A que ele próprio escrevera não chegou à Europa, creio eu, enquanto a segunda, além de ir ao seu destino, foi reproduzida parcialmente em jornais e brochuras." (DE-2:96, grifo nosso) 
De fato, o Anexo - VII do DE-1 traz uma carta do colono Friederich Wehrsig, a seu irmão, na Alemanha, bendizendo as condições de trabalho no Ibicaba; a atitude do narrador é faroleira como se descrevesse o paraíso. Encontramos a suspensão da descrença de Bruner (2001 em 2.6.a), aparentemente encontrou o que procurava:

- "Naturalmente vai perguntar, como é possível viver num país estranho, com seis pessoas, durante sete meses, sem ter dinheiro, pois sabe que não trouxe nenhum. Isto acontece naturalmente da seguinte maneira: no primeiro tempo quando ainda não se é alguém, vai se buscar os gêneros de primeira necessidade e também dinheiro na fazenda ou do diretor da colônia, pagando isso quando se pode ou quer (...) eu mesmo já tenho cerca $\mathbf{4 0}$ galinhas, e neste tempo comi mais carne de galinha do que em toda minha vida na Alemanha (...) quem trabalha das 6 as 10 e das 3 as 6 regularmente, ganha tanto que ainda pode economizar alguma coisa..." (DE-1, Anexo VII, grifo nosso)

O narrador Davatz expressa seu choque com os valores éticos de como deve ser tratada a correspondência e defende a liberdade e sua postura de tentar resolver as questões democraticamente, de acordo com os argumentos que possui:

- "O leitor benévolo que julgue se houve ou não motivos para as medidas que tomamos, se realmente empreendemos uma revolução contra as autoridades do país e desprezamos os recursos que a lei nos oferecia, como o pretendem nossos adversários. (...) Só sei que nada poupei a fim de, por um lado, conseguir a assistência necessária para os colonos e, por outro, evitar da parte destes qualquer violência ou injustiça contra a casa Vergueiro e os demais fazendeiros." (DO-2:174, grifo nosso)

Segundo Bosi (2003), é através de depoimentos que percebemos como pessoas que compartilharam uma mesma época, ou um mesmo 
acontecimento, constroem significados totalmente diferentes e contraditórios a respeito do que vivenciaram:

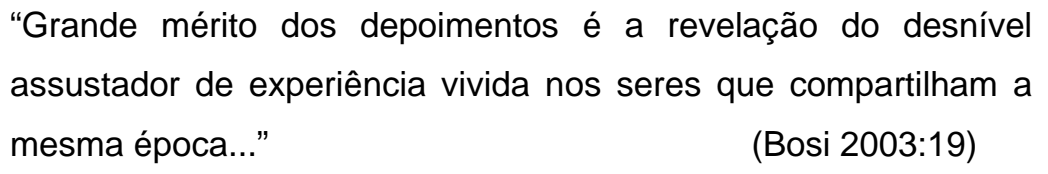

Podemos compreender tais conflitos culturais e choques entre construções divergentes da realidade vivenciada através das reflexões de Menezes de Souza:

\begin{abstract}
"Em termos de contatos inter- e trans-culturais, vê-se a importância do conceito de cultura e de língua como emergentes, dialógicos, performativos, contingentes e dinâmicos; por um lado, embora a visão de cultura e língua como estruturas normatizadoras que geram ações previstas pode supostamente prever e explicar os conflitos culturais que ocorreriam em momentos de contatos entre conjuntos normativos assimétricos, ela não poderá explicar mudanças nas estruturas; por outro lado, a visão emergente e performativa pode não apenas explicar mudanças (atribuindo agência aos membros e interlocutores), mas também pode explicar porque os conflitos esperados podem não ocorrer (devido a possibilidade de indeterminação e contingência)."
\end{abstract}

(Menezes de Souza 2006:14, grifo do autor)

O autor explica que as relações inter ou transculturais evidenciam a necessidade de compreendermos que a cultura e a língua são processos de ação dinâmicos, dialógicos, contingentes, que emergem na relação performativa com o contexto, possibilitando a explicação do fato de mudanças ocorrerem ou não. Através do conceito normatizador de cultura e de língua, poderíamos prever que os membros da Vergueiro \& Cia., que faziam parte da elite brasileira, construíssem significados a partir de conceitos positivistas e liberais, vigentes na maioria dos contextos do século XIX, e o conseqüente conflito que houve com colonos europeus que vivenciaram o deslocamento, o afastamento e o questionamento de valores. Mas, é através 
do conceito emergente e performativo de linguagem e de cultura que compreendemos a contingência e a indeterminação presentes nas identidades que fogem à regra.

Viemos demonstrando, até aqui, que lidamos com nossa contingência e com nossa indeterminação identitárias, através de um processo de ação emergente e performativo da nossa vivência contextualizada, na expectativa de garantirmos nossa construção de significação, seja ela a partir de uma posição de inclusão e de pertencimento, como as identidades nacionais, a exemplo do Senador Vergueiro, que tem seu direito de narrar garantido, ou a partir da posição de deslocamento e de incômodo da identidade estratégica que o imigrante, a exemplo de Thomas Davatz, passa a vivenciar no encontro de culturas.

\subsection{Identidade Progressista do Imigrante}

Como exemplo de conflitos que não ocorrem, podemos verificar a performance da família Levy, conforme narrativa do Documento Escrito DE-3 - Família Levy (1997) - de colonos que carpiam e colhiam em Ibicaba conseguiram, no espaço de quinze anos, saldar dívidas com o Senador Vergueiro, além de guardar capital para abrir seu próprio negócio na cidade de Limeira. Em 1890, passaram a donos da fazenda Ibicaba e concretizaram o sonho de abraçar a terra que os recebera, tecendo uma teia de realizações nas cidades de Limeira, Cordeirópolis, Pirassununga e Santos.

Para a Família Levy, vindos de Bollendorf, Kreis Bitburg, Alemanha, que chegaram em 1857, após a rebelião de Davatz de 1856 e antes da proibição da imigração pelos governos europeus, que aconteceu em 1859, a perspectiva da narrativa é focada na identidade de imigrante empreendedor, que consegue realizar o sonho a que veio e pode, finalmente, narrar sua versão por ter historicamente - adquirido tal direito. O livreto publicado em 1997, que comemora os 140 anos da família no Brasil, que traz texto de Cássio de Freitas Levy, declara: 
- "Os Levy aqui chegaram em 3 de agosto de 1857, na terceira leva de imigrantes alemães, contratados por Vergueiro e Companhia, para trabalharem como colonos, na grande extensão de terras onde o Senador Vergueiro, com notável visão do futuro, fez a primeira experiência coroada de êxito no Brasil do trabalho livre".

(DE3:9, grifo nosso)

Percebemos que a narrativa da família Levy reforça a identidade do Senador Vergueiro como a de um homem visionário e bem sucedido nacionalista. Esses colonos, apesar de serem de outra cultura, ao se depararem com a nova, trataram de abraçá-la, inclusive abrindo mão de sua religião, não vivenciaram a questão como imposição, mas como mediação e enaltecem a visão de futuro dos Vergueiro:

- "Os Levy, como o nome mostra, eram de origem judaica, mas creio que quando chegaram ao Brasil já seguiam uma religião cristã (protestante provavelmente), pois nunca percebi indício nenhum de judaísmo neles, mesmo nos mais velhos. Dona Maria Angélica Vergueiro, esposa do Senador Vergueiro, pessoa boníssima, ao chegarem os imigrantes trouxe um padre católico para procurar convertê-los. Os Levy abraçaram então o catolicismo e Dona Maria Angélica Vergueiro batizou o José, o caçula, ou melhor, foi sua madrinha. Excelente madrinha como o futuro mostrou".

(DE-3:9, grifo nosso)

Novamente, conforme Bruner (2001 em 2.6.a), a interpretação narrativa dá forma às realidades que cria, sendo que suas ações têm motivos e seguem convenções e expectativas socialmente construídas. O espírito empreendedor dos Levy teve maior peso na construção narrativa da realidade que o choque e o conflito cultural, como no caso de Davatz; estes abraçam a religião dos patrões, minimizando, assim, os conflitos e chegam, inclusive, a comprar a fazenda dos patrões; o importante é narrar sua história de sucesso, comprovar sua identidade de ex-colonos abastados: 
- “Ao saírem de Ibicaba, em 1871, receberam 982\$133. Com suas economias foram para Limeira onde se estabeleceram comercialmente com Venda, Açougue e Selaria (negócio altamente rentável naquela época de transporte animal). José foi tropeiro e do gado obtido proviam o açougue e o couro para a selaria.(...) Com o capital adquirido no seu comércio, fundaram uma casa bancária e, com os lucros desta, tornaram-se abastados capitalistas e puderam concorrer ao leilão da Fazenda Ibicaba e ganhá-lo. Tornaram-se, assim, proprietários daquelas terras em que haviam trabalhado como colonos. A Fazenda Ibicaba, com 1.003 alqueires de terra de primeira, devido a uma série de infelicidades da família Vergueiro fora posta a venda em hasta pública em 1890."

(DE-3:9, grifo nosso)

Bosi (1994), que se dedicou cuidadosamente ao estudo do percurso da memória na sociedade, ajuda-nos a compreender os caminhos que esta percorre, ao reforçar determinados "universos de significado" que the convém, versões consagradas dos fatos são narradas e impressas repetidamente enquanto que procura esquecer o que não é significativo, o que não foi testemunhado por vários membros da comunidade; enfim, esquece nossas interpretações individuais que podem ser consideradas imaginação por não receberem o reforço dos outros:

\footnotetext{
"Um dos aspectos mais instigantes do tema é o da construção social da memória. Quando um grupo trabalha intensamente em conjunto, há uma tendência de criar esquemas coerentes de narração e de interpretação dos fatos, verdadeiros 'universos de discurso', 'universos de significado', que dão ao material de base uma forma histórica própria, uma versão consagrada dos acontecimentos. O ponto de vista do grupo constrói e procura fixar a sua imagem para a história. Este é , como se pode supor, o momento áureo da ideologia com todos os seus estereótipos e mitos. No outro extremo, haveria uma ausência de elaboração grupal em torno de certos acontecimentos ou situações. A rigor o efeito, nesse caso, seria o de esquecer tudo o que não fosse 'atualmente' significativo para o grupo de convívio da pessoa. É o que sucede às vezes: os fatos que não
} 
foram testemunhados 'perdem-se', 'omitem-se', porque não costumam ser objeto de conversa e de narração, a não ser excepcionalmente. Assim, quando o sujeito os evoca, não vem o reforço, o apoio contínuo dos outros: é como se ele estivesse sonhando ou imaginando; e não por acaso duvidamos, hesitamos, quando não nos confundimos, sempre que devemos falar de um fato que só foi presenciado por nós, ou que sabemos 'por ouvir dizer'". (Bosi 1994: 66, grifo nosso)

A performance da família Levy emergiu de acordo com as expectativas socialmente construídas pelo nacionalista Senador Vergueiro, em seu empreendimento de contratar imigrantes de cunho particular, chegando até a superá-las por conseguirem igualar-se aos patrões. Diante do desempenho dessa família, vemos que a aquisição do direito de narrar na escala social, muitas vezes, reforça grandes narrativas nacionalistas.

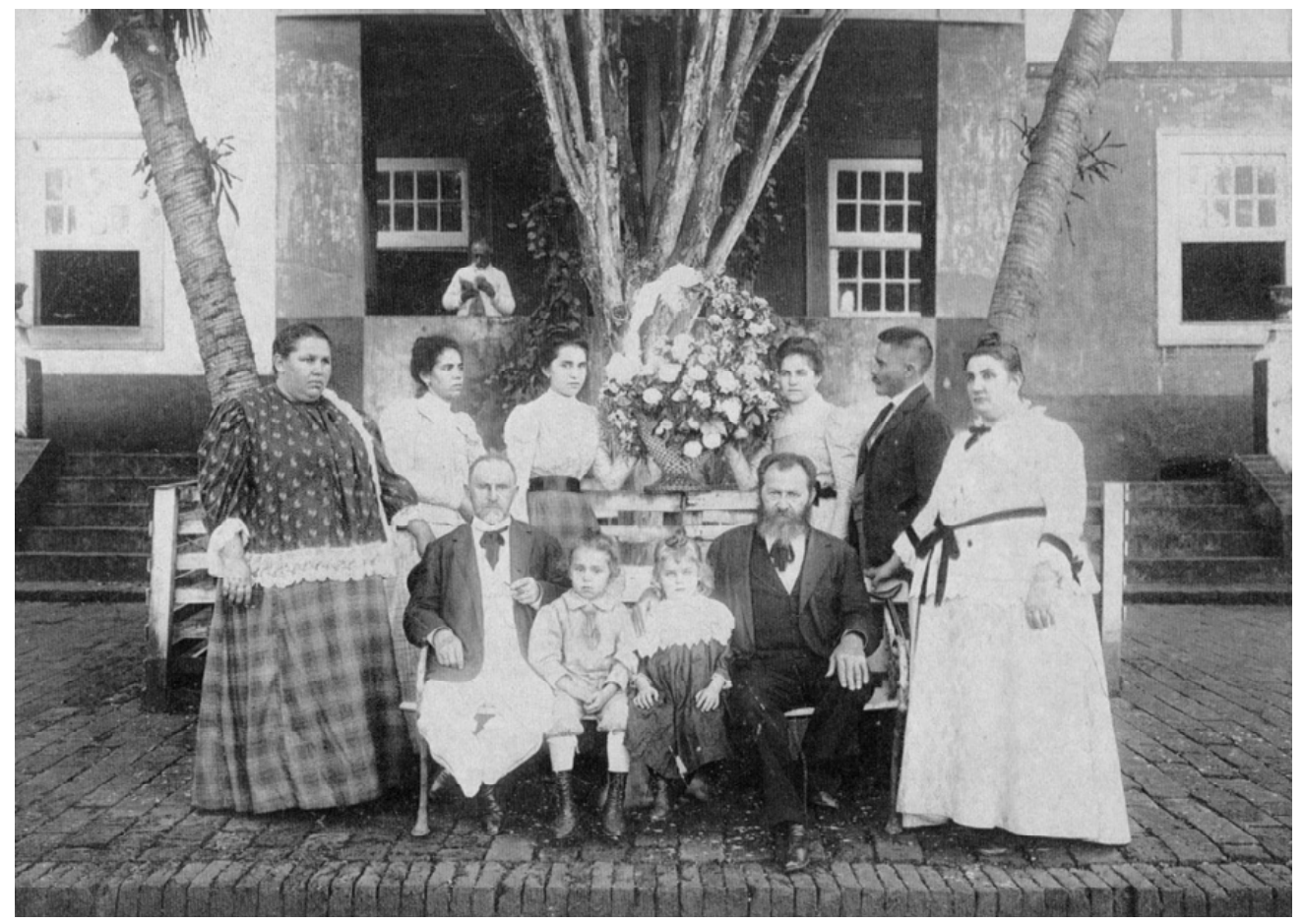

Em primeiro plano, da esquerda para a direita: Amália Roland Levy, Coronel José Levy, Huberto Levy, Jacob Emílio Levy (com roupa de menina), Simão Levy e Anna Quintus Levy. Em segundo plano: Lydia Levy, Albertina Levy, Maria Levy e Joaquim Manoel Pereira. Imagem captada em frente ao velho casarão dos Vergueiro na Fazenda Ibicaba, por volta de 1892-93. Acervo: Família Levy. 


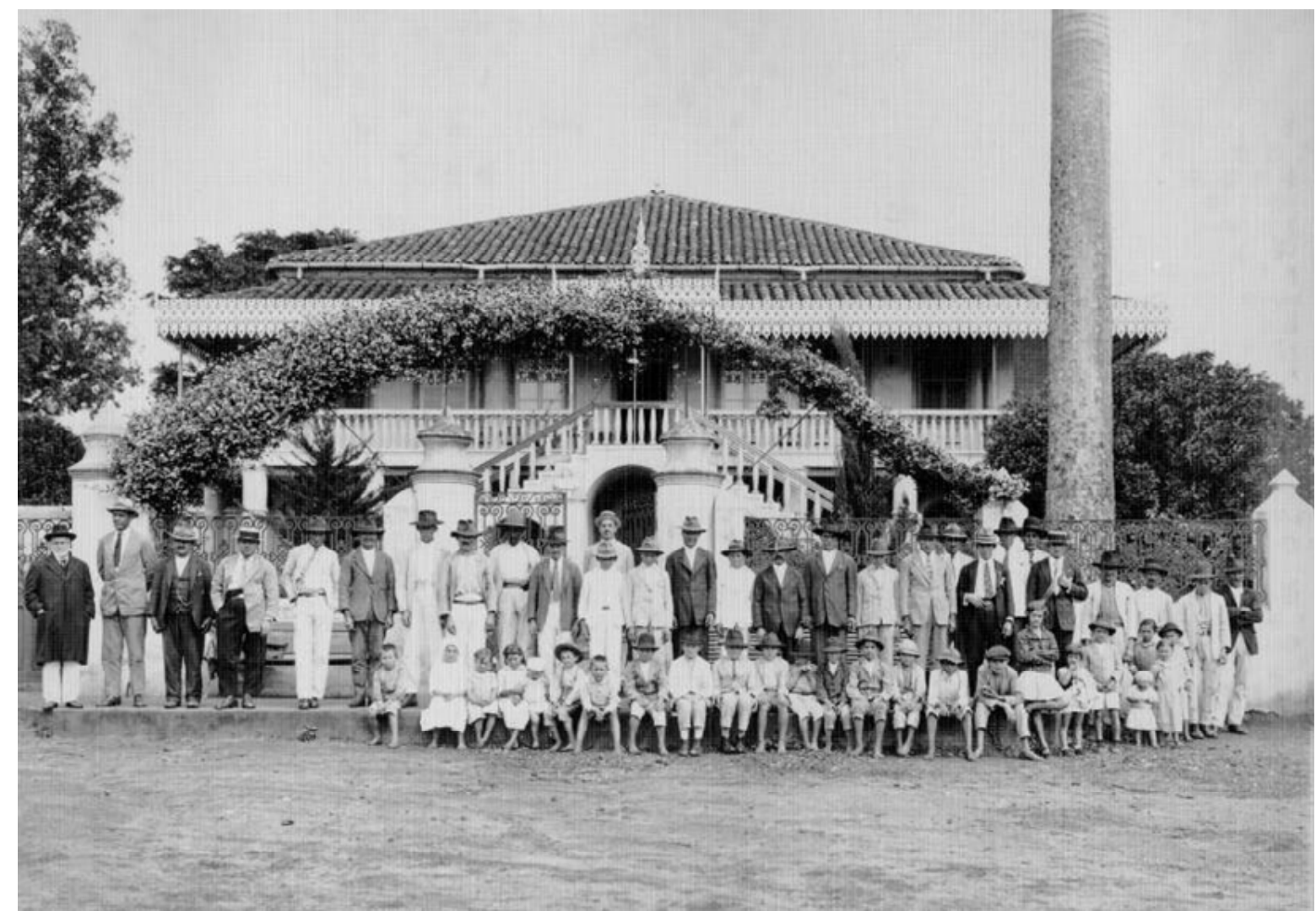

Nova sede da Fazenda Ibicaba: à esquerda o Coronel José Levy, ao centro Huberto Levy, acompanhados de seus funcionários e crianças. Foto da década de 1920. Acervo: Família Levy.

\subsection{Identidades Híbridas nas Raízes do Passado}

Assim, dando seqüência às narrativas que compõem esta pesquisa, o polêmico Comendador José Vergueiro, filho do senador, em um ato de generosidade, adota Catharina Vergueiro, nascida em 1852, no norte da Alemanha, filha de Catharina Drenkhan, uma pobre imigrante mãe-solteira que veio para o Brasil, movida pelo "sonho de felicidade", mas falecida após sua chegada ao porto de Santos. Catharina Vergueiro casou-se com o alemão Detlef Brune, administrador da fazenda e teve, com ele, nove filhos. Detlef retornou com os filhos para a Alemanha, após a morte de sua esposa em 1887, mas a filha mais velha Carlota Schmidt, nascida em Ibicaba em 1875, escreveu suas memórias sobre a fazenda quando ainda menina e sem ter passado pela experiência do deslocamento; ela havia ido à Europa apenas como turista ainda. 
Bruner (1986 em 2.6.a) explica que tanto o pensamento lógico-científico quanto o narrativo criam uma verdade e acessam nossa canonicidade, seja ela científica, seja plausível culturalmente; ambos são construções sócio-históricas contextualizadas. Também Bosi (2003) esclarece sobre o direito de narrar adquirido pelas pequenas histórias diante da crise de identidade:

\footnotetext{
"Quando nos anos setenta, as grandes teorias da história, como a teoria evolucionista, a teoria hegeliano-marxista entram em crise, entra em crise também o sentido da História Política. O oceano de pequenas estórias tomará o seu lugar, como a estória do descontínuo, do pontual, do que parece fragmentário, ao ponto de esquecer o tecido histórico que sustenta os fatos..."
}

(Bosi 2003:14)

A autora de "Recordações de Infância de Carlota Schmidt no Ibicaba" DE4, nascida em 1875, está distanciada no tempo dos acontecimentos históricos vividos por Davatz e os Levy, mas, por conviver com o avô José Vergueiro, filho do Senador, que esteve envolvido nos acontecimentos relatados, e que ainda responde pela Casa Vergueiro, constrói a faceta da identidade deste, a partir do lócus de enunciação e da vivência como neta amada gerada pela filha adotiva, julga-o importante, justo e bondoso:

- "Meu avô, José Vergueiro, e a avó, Maria Umbellina, tinham uma filha, Catarina Brasília, que era nossa mãe. Pequena e delicada, pele alva, lindos olhos marrom escuros, sempre meiga, quieta e bondosa. Meu pai veio para a plantação, como diretor comercial e tornou- se o braço direito do meu avô. Este era uma figura de homem imponente, de feições enérgicas, um 'gran- senhor'”.

(DE-4:19, grifo nosso)

- "Seu pai foi governador do Brasil, antes da emancipação de D. Pedro II. Dele origina- se a grande corrente de ouro. Ele era um homem, que impunha respeito mas, nós crianças, sentíamos sempre que ele nos amava muito. Ele adivinhava nossos desejos e sempre tinha uma novidade para nós. Todos na fazenda o olhavam com um pouco de 
temor. Ele era um administrador severo, mas justo". (DE-4:20, grifo nosso)

- "Um dia Vovô me deu um bonito cavalinho, manchado de marrom e branco, o qual recebeu o nome de Amy."

(DE-4:26)

- "Vovô me presenteou com um saco de café, que eu deveria levar para minha avó alemã e a mim pessoalmente deu-me cem mil reis." (DE4:34)

- "Ibicaba recebia muitas visitas importantes e às vezes eu vi algumas e fiz reverências a elas. Meu avô sempre nos mostrava com orgulho, talvez pensando que seria uma grande recordação para nós." $(D E-4: 40)$

Conforme discutimos com Bhabha (1994 em 2.7.c), toda cultura é híbrida, não no sentido de mestiçagem, mas de coexistência em um terceiro espaço intersticial onde os fundamentos não se sustentam, espaço de indeterminismo onde as ideologias se colocam e se procuram negar; identidade não é aquilo que se diz ser, mas o que o contexto produz, resignificamos em contextos diferentes aquilo que, no encontro com o outro, fica visível. Esta seria a tradução cultural.

No caso de Carlota Schmidt, o hibridismo social e cultural fica visível devido ao fato de ser filha de pais imigrantes alemães e neta da elite cafeeira brasileira, que é também escravagista e racista. Sua identidade sofre uma resignificação no encontro com o sofrimento de um negro, pois, até então, achava que os negros eram seus amigos:

- "Das muitas pessoas que nos rodeavam, podiam-se criar pequenos círculos de amizade. Em primeiro lugar as babás negras tinham grande influência. Entre as filhas dos 400 escravos eram selecionadas as melhores, que cuidavam e brincavam conosco. Daí 
eu meu recordo com alegria de Micelina e Agida; as quais sabiam nos entreter gostosamente."

(DE-4 :29, grifo nosso)

- "Entre os negros, tinha um que sempre andava com corrente na perna e colar de ferro, como castigo para quem havia fugido. Ele sempre nos pedia gemendo e com lágrimas, para que pedíssemos ao avô, para livrálo dos ferros, que ele nunca mais fugiria. Nós pedimos e conseguimos libertá-lo, mas no dia seguinte ele tinha fugido e nós ficamos muito decepcionados, mas serviu como lição." (DE-4:31, grifo nosso)

Mesmo enquanto criança e neta amada que idolatra o avô, ousa refletir sobre o sofrimento dos negros, ao vivenciar uma situação de conflito de valores e de verdades; mas, apenas para rapidamente chegar à conclusão que o avô é que está certo, reiterando a identidade dele criada no contexto da família, sem sequer - imaginar o verdadeiro sofrimento de um escravo. Expressa valores de sua comunidade e não percebe que a atitude do negro, ao conquistar a compaixão dos netos do seu senhor implacável - que, para ele, era a tortura em pessoa -, valeu-Ihe a tão preciosa liberdade e que se este tivesse o direito de narrar sua vivência, provavelmente, poderia convencer-nos de outras verdades. 


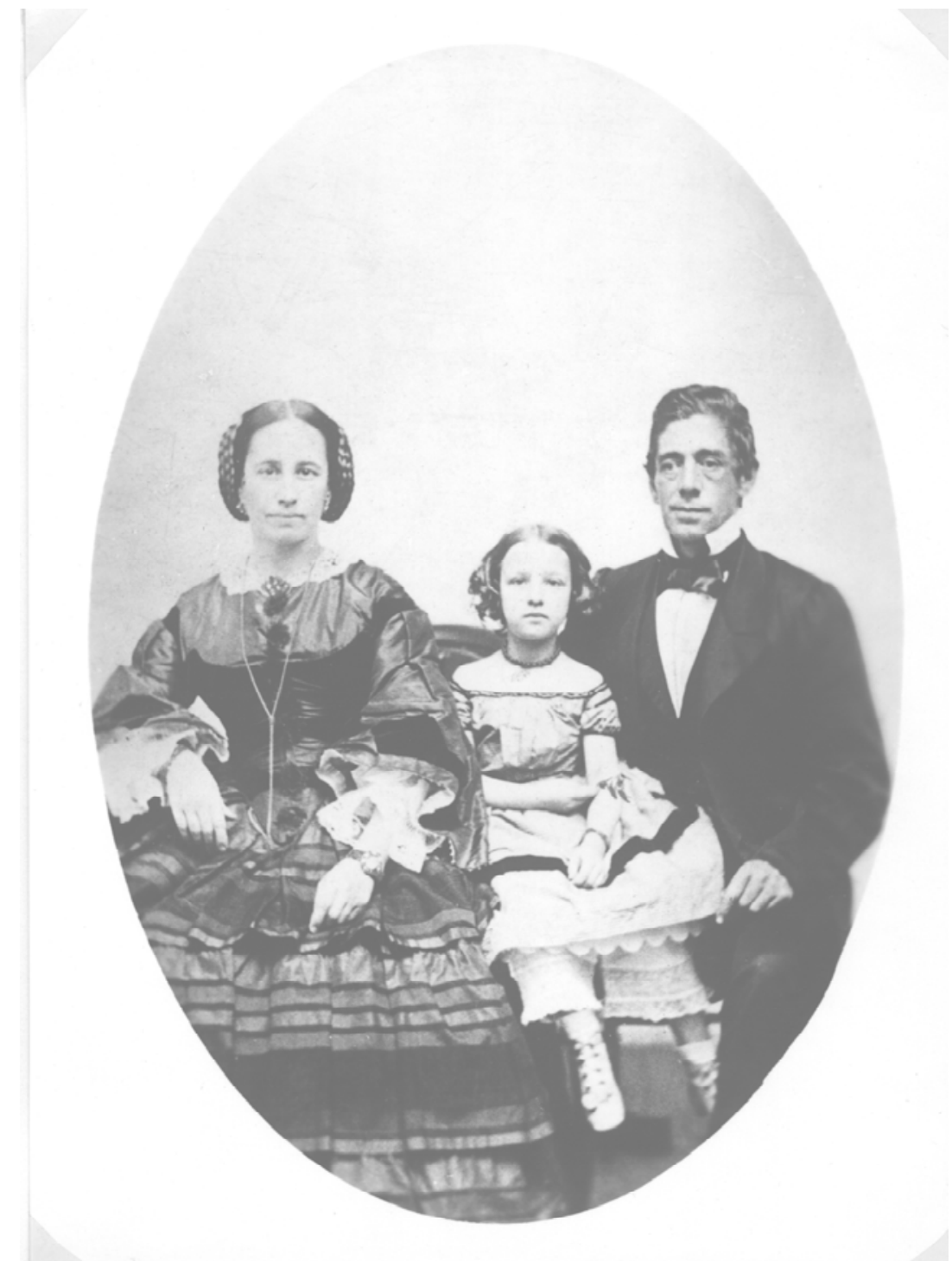

José Pereira de Campos Vergueiro, sua esposa, Maria Umbelina Gavião Peixoto e a filha adotiva, Catharina Drenkhan / Vergueiro. Acervo: Dra. Lotte Köhler - Munique. 


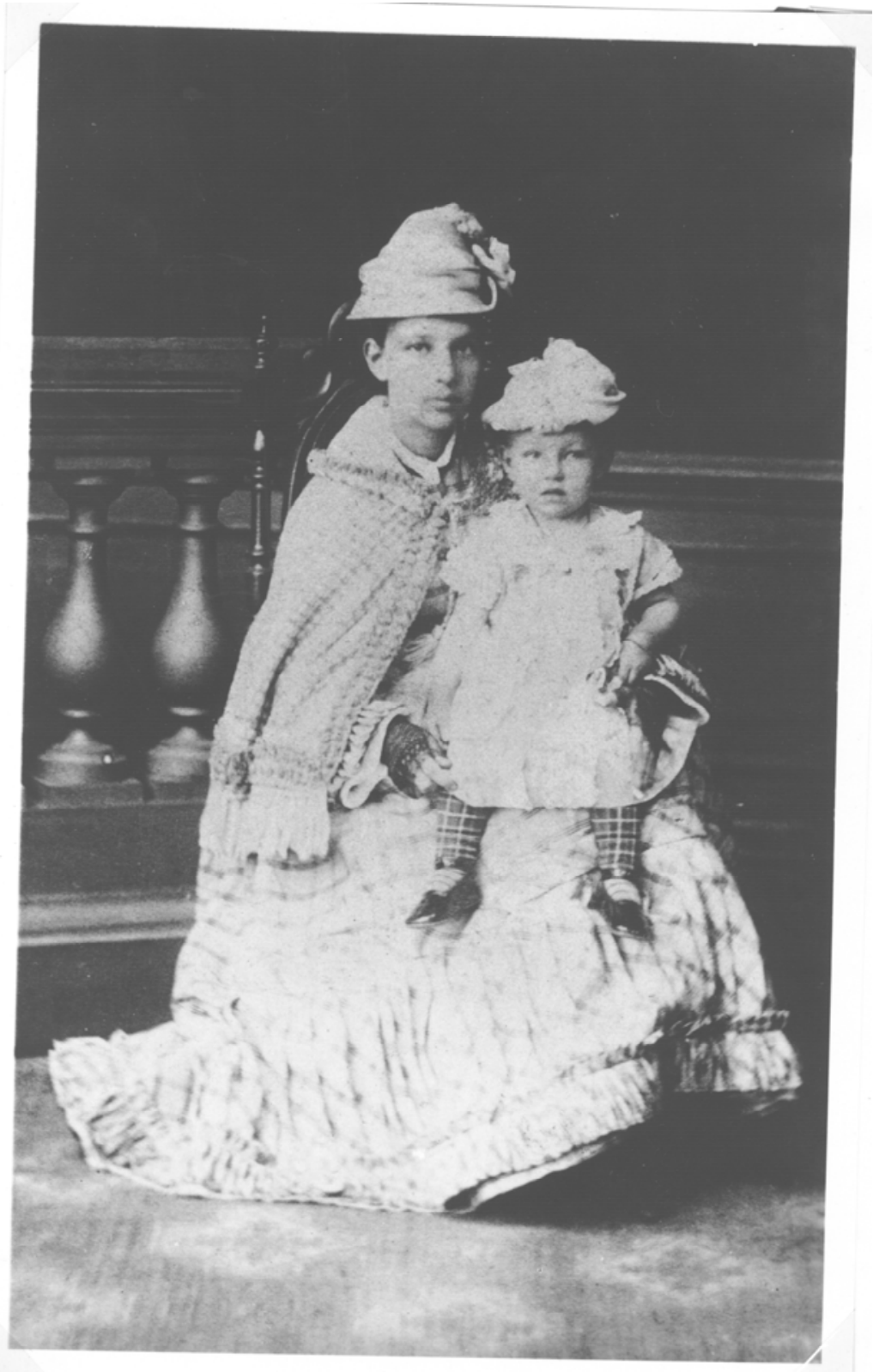

Catharina Drenkhan / Vergueiro com sua filha Carlota. Acervo: Dra. Lotte Köhler - Munique. 


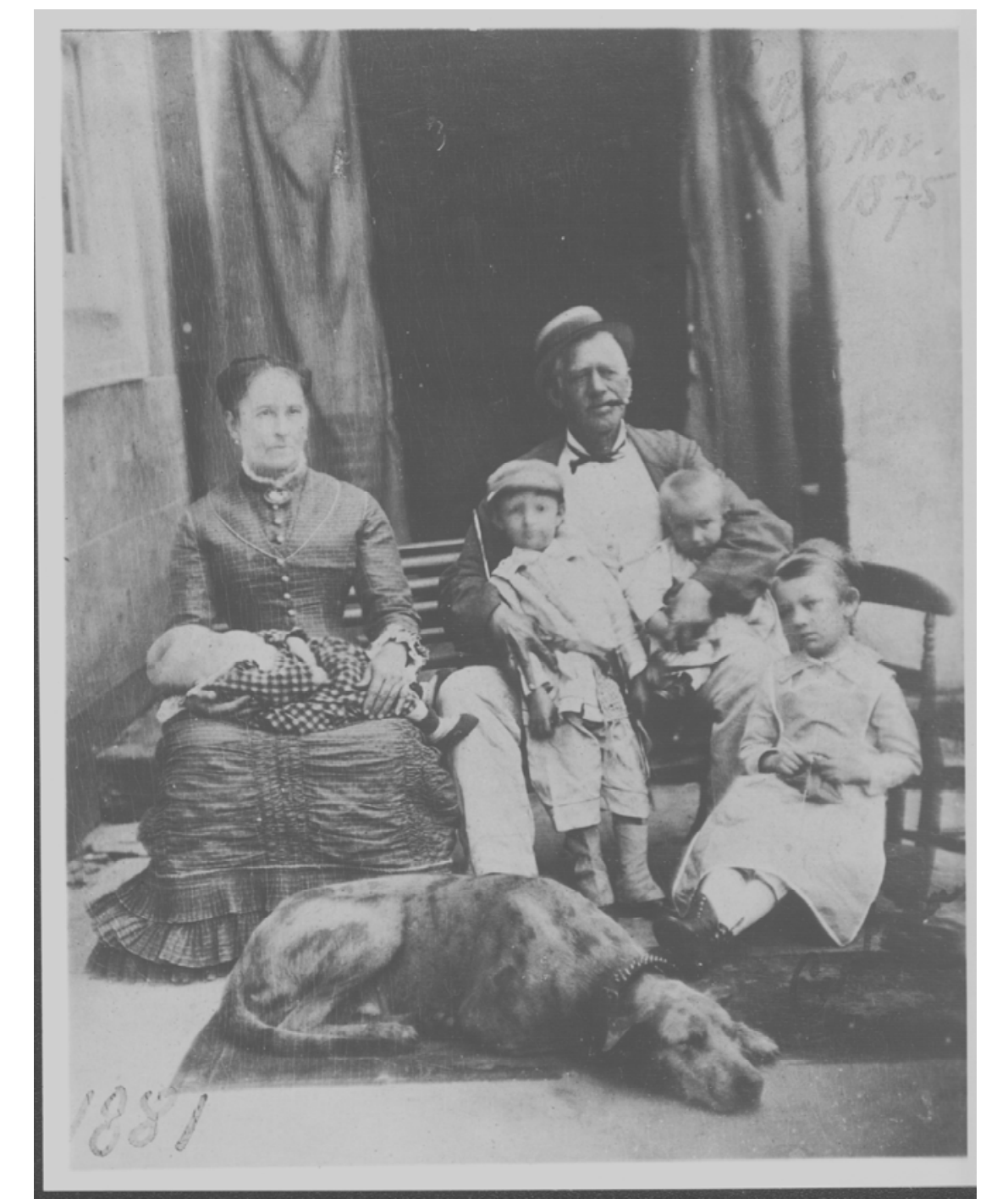

José e Umbelina Vergueiro, com os netos: Carlota, Augusto, João e Walter. Deitado no tapete, o cão Hektor. Foto de 1881. Acervo Dra.Lotte Köhler - Munique.

\subsection{Vivenciando o Hibridismo Aqui e Agora}

As teias de narrativas e de identidades que se desenrolam, através dos tempos, emergem no nosso aqui e agora performativo, dependendo da possibilidade de exercermos o direito de narrar. Até o presente momento, analisamos documentos escritos que registraram pareceres que, de alguma forma, foram aceitos por suas comunidades uma vez que publicados; passaremos, então, a analisar depoimentos orais gravados em DVD, que são representativos de uma mídia muito mais utilizada na nossa época e são valorizados por abrirem espaço para pontos de vista contraditórios poderem existir e por exibirem nossa sensibilidade e nossa mentalidade. 
A neta mais velha de Carlota Schmidt, a Dra. Lotte Köhler, médica psicanalista de 82 anos de idade, até a presente data (2007) residente em Munique, encontrou as recordações da avó e percebeu o pequeno tesouro histórico que possuía; conseqüentemente, tentou publicá-las e se decepcionou com a falta de poder narrativo de que dispunha, até que o pesquisador José Eduardo Heflinger Jr. resolveu exercer seu papel de narravinte e de editor. Lotte faz um depoimento oral DO-5, gravado em DVD, para o lançamento do livro "Recordações de Infância de Carlota Schmidt no Ibicaba" DE-4, em 16 de Junho de 2005, no Goethe Institut em SP, e 13 de Julho de 2005 na Fazenda Ibicaba, com sua construção narrativa dos acontecimentos. Ao comentar a história de sua avó Carlota Schmidt - DE-4 - no depoimento oral em DVD DO-5, Lotte, com 80 anos na ocasião, declara que "a história deste livro é um moderno conto de fadas", pois esta é sua construção de identidade a partir das narrativas familiares que herdou, inclusive canta uma música que sua avó provavelmente vivenciou na época dos escravos:

- "Sobre sua infância, como neta de José Vergueiro, em ambiente quase feudal, com babá escrava e também seus avós amorosos, no convívio diário da casa, ela transmite suas lembranças. (...) Naturalmente, ela contou sua vida em Ibicaba. Ainda hoje eu sei cantar uma musiquinha que os nativos lá cantavam".

(DO-5, grifo nosso)

A Dra. Lotte, munida das narrativas herdadas sobre a grandiosidade dos Vergueiro, fica chocada ao perceber que existem opiniões contraditórias acerca da identidade dos mesmos, como demonstraremos a seguir. Para nos ajudar a compreender pontos de vista contraditórios presentes na memória oral, Bosi (2003) explica que sua maior riqueza é permitir que tais pontos de vista distintos venham à tona e ilustrem a História das Mentalidades, a História das Sensibilidades:

A memória oral, longe da unilateralidade para a qual tendem certas instituições, faz intervir pontos de vista contraditórios, pelo menos distintos entre eles, e aí se encontra a sua maior riqueza. 
Ela não pode atingir uma teoria da história nem pretende tal fato: ela ilustra o que chamamos hoje a História das Mentalidades, a História das Sensibilidades".

(Bosi 2003:15)

Apesar do seu lócus de enunciação enquanto psicanalista, a Dra. Lotte demonstra espanto ao perceber o complexo de narrativas em torno da identidade da Casa Vergueiro:

- "Os senhores podem imaginar minha surpresa, quando, aproximadamente 15 anos atrás, apareceu no jornal Frankfurter Allgemeinem, um romance em capítulos da conhecida autora Evelyn Hassler, com o título: 'Ibicaba, o paraíso na imaginação das pessoas'. Eu não acreditei nos meus olhos, pois se tratava da nossa Ibicaba! Eu escrevi para Evelyn Hassler, sobre as lembranças da minha avó. Mandei também fotos da fazenda. Eu nunca recebi resposta, o que, para mim, tornou-se compreensível, porque, segundo trabalhadores suíços, os Vergueiro eram duros escravagistas. Isso só apareceu nos capítulos seguintes.

Através desse romance, eu soube o outro suposto lado dos Vergueiro, que para mim, só eram os amorosos avós de minha avó. Pela dissertação de Beatrice Ziegler, tomei conhecimento da maneira como os Vergueiro importavam trabalhadores pobres da Suíça e da Alemanha, quase como uma indústria para obter trabalhadores baratos, para as plantações de café, onde se tornavam escravos melhorados.

As comunidades de lá, davam dinheiro para as passagens, para se livrar das pessoas incômodas, as firmas no Brasil ofereciam crédito para que essas pessoas trabalhassem, pagando com o trabalho. As cláusulas eram tais que as dívidas nunca chegavam a ser liquidadas.

Eu como psicanalista e ser humano me pergunto: como é possível tamanha discrepância de personalidade?

Aqui, amoroso pai e avô, lá explorador de escravos. Nós temos, tanto na história antiga como na moderna, exemplos disso, como os 
colonialistas e os poderosos agiam. Pessoas que eram bons pais ou mães de família, fora do ambiente familiar podiam maltratar, até a ponto de roubarem a dignidade das pessoas.

(DO-5, grifo nosso)

Ao perceber que a realidade não é transparente, o estranhamento da psicanalista passa a ser com a grande narrativa histórica sob perspectiva européia, que defende seus cidadãos que sofreram sob o comando dos gananciosos escravocratas Vergueiro. Ela tenta justificar o hibridismo que detecta com exemplos históricos entre colonialistas e poderosos que conviviam com valores contraditórios. Inconformada por ter vivenciado outra identidade, através das narrativas que herdou da avó, procura, novamente, lutar pelo seu direito de narrar "a verdade":

- "Depois da leitura do romance, durante longos anos, não pensei em Ibicaba. Mas em 2003, quando estava na estação de águas de Ragaz, para tratamento, li num jornal suíço, que no Johann Jacobs Museum havia uma exposição sobre suíços, nas plantações de café no Brasil, e a Lotte Köhler foi lá. O museu estava fechado, mas, eu toquei a campainha e consegui falar com a curadora. Eu contei a ela toda a minha história. Ela ficou encantada. A exposição seria prolongada com peças de lembranças da família Brune/Schmidt, mas, depois de algum tempo, eu recebi a notícia que esse não seria o caso. Será que minhas informações não se encaixavam no conceito que eles tinham dos 'maldosos' Vergueiro?” (DO-5, grifo nosso)

Ela experimenta, em um curto espaço de tempo, a sensação de possuir o direito de narrar sua versão dos fatos e, imediatamente, de lhe ser tomado tal direito, por, talvez, não corresponder aos interesses do poder vigente.

O hibridismo sempre esteve presente nas construções identitárias dos indivíduos ao longo da história, mas as versões oficiais escritas, presentes principalmente nos documentos históricos, costumam ser unilaterais e nem sempre permitem a percepção do complexo híbrido de identidades que 
constituem cada um de nós, apesar de sempre estarmos interpretando aquilo que lemos a partir de nossa vivência de significação. Conforme vimos com Derrida (1978 em 2.3), o texto congela a fala e a intenção do falante, não há garantia de significado. Já a memória oral, conforme Bosi (2003), permite uma maior gama de possibilidades, já que se transforma através do tempo e do espaço com cada narrador e narravinte que vivenciam a narração e a audição a seu tempo.

\subsection{Conquistando o Direito de Narrar}

Viemos demonstrando, até aqui, como nossas construções narrativas de identidade acontecem através de um processo de ação performativo, vivenciado em um determinado contexto, e como elas expõem o complexo híbrido de identidades presentes em cada contexto que vivenciamos.

Prosseguindo com os acontecimentos da comunidade pesquisada, ironicamente, após ser organizado por José Eduardo Heflinger Jr. - do Projeto Imigração Resgate, o qual empreendeu 22 anos de pesquisas em inúmeros acervos públicos e particulares do Brasil, declarado em diversos jornais como sendo historiador, apesar de não diplomado, de acordo com o qual "a história da imigração está toda ainda por fazer", o livro Recordações de Infância de Carlota Schmidt no Ibicaba - DE-4 foi lançado no mesmo Johann Jacobs Museum - Museu do Café, em Zurique, no dia 30 de Setembro de 2005, que previamente havia recusado essa versão dos acontecimentos e passou a lhe conceder status de verdade, com a presença de autoridades representativas da identidade nacional: embaixadora do Brasil Sra. Celina M. Assumpção do Valle Pereira, que a exemplo do Ministro Flávio Macieira e do responsável pelo departamento cultural da Embaixada do Brasil em Berna, Sr. Cosme Silva, viajaram para Zurique especialmente para prestigiar o evento. Também estiveram presentes o Cônsul Geral do Brasil em Zurique Sr. Adolpho C. S. Benevides; Dra. Cláudia Schallenmüller, filha do Cônsul Honorário da Alemanha em Ribeirão Preto, que, por sua vez, viajou da Alemanha para prestigiar a apresentação, cuja cobertura na imprensa européia ficou a cargo 
dos jornalistas editores da Revista e do Jornal Perfil, com circulação na Alemanha e na Suíça.

Como vimos com Bhabha (2001 em 2.6.d), a nacionalização encontra-se em um momento transicional e tradutório e é importante percebermos qual parte da nação está sendo reciclada e reiterada, transformada, reaproximada e retraduzida. Constatamos o ritual problemático e intrincado na junção da memória pública, do testamento público, na tentativa de encontrarmos algo em comum no nosso modo dividido de ser, propiciado pelos movimentos migratórios e, até mesmo, os que não são migrantes vêem seu chão renomeado como palco de situações históricas conflitantes. Vivenciam um influxo de pessoas com narrativas próprias, histórias próprias, onde a narrativa de enunciação ganha força e poder específicos para modificar a história, enquanto poiesis da prática social e política. Fazer leis, ética, história ou, até, um evento fazem parte do direito de narrar.

O pesquisador José Eduardo Heflinger Jr. conquistou o direito de narrar e palestrou, também, no Deustch Brasilianish Kulturverein em Munique, onde a Dra. Lotte Köhler foi homenageada; participou de conferência na Universidade Lusófona de Humanidades e Tecnologia em Lisboa; doou o livro de Carlota Schmidt - DE-4 - para os museus "Link to your Roots" em Hamburgo, German Immigration Center - "Auswandererhaus" - Casa do Imigrante, em Bremerhaven, para a biblioteca da cidade de Hamburgo e para o Instituto de Estudos Ibero-Americanos. Doou livros e pesquisou nos castelos da Turíngia: Rudolstadt, Weimar e Gotha, sendo que, nesse último, foi recepcionado pelo diretor geral de todos os arquivos documentais da Turíngia, Sr. Lutz Schilling. Os castelos abrigam arquivos contendo os nomes dos migrantes que deixaram a Alemanha, ainda não unificada, com destino ao Brasil, mais especificamente à Ibicaba e a outras fazendas representativas do período áureo do café. Requisitado por jornalistas e por editores da Rádio e Televisão Portuguesa em Lisboa, Heflinger Jr. assessorou-os na edição de uma minissérie intitulada "Eilos Que Partem", considerada pela crítica como o documentário mais interessante sobre o tema imigração, veiculado pela televisão portuguesa. 


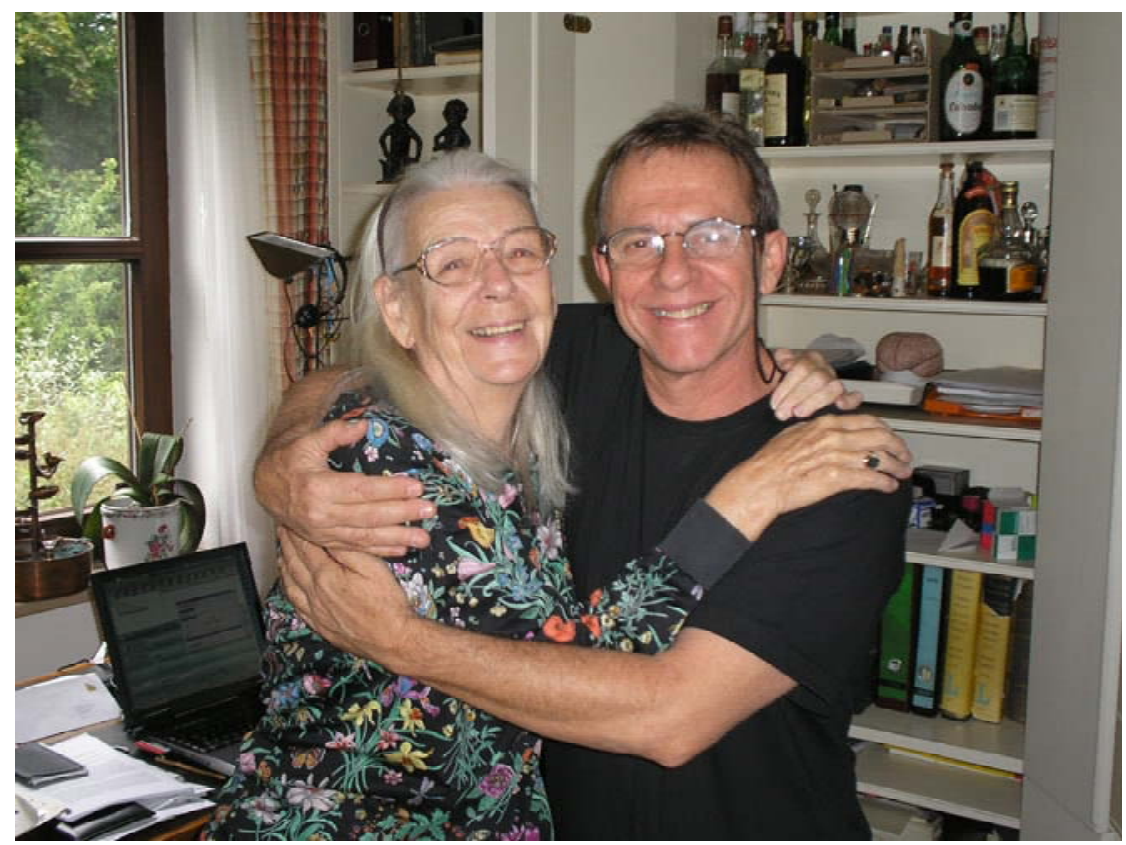

Dra. Lotte Köhler e José Eduardo Heflinger Júnior. Acervo: Imigração Resgate.

Daí o caráter de moderno conto de fadas que não apenas transforma uma imigrante órfã em filha de políticos poderosos, mas também publica as memórias narradas de sua neta com reconhecimento público e, conseqüentemente, histórico. A narrativa da neta dos grã-senhores do Brasil foi considerada emotiva, pessoal e subalterna na Europa, para, em seguida, conquistar o status de grande narrativa e que é, constantemente, reiterada. Lotte afirma:

- "Minha família e eu temos todos os motivos de sermos agradecidos à família Vergueiro e juntamos à apresentação do livro, nosso secreto desejo de conhecer os descendentes desses benfeitores. Naturalmente, nós, os dez netos de Carlota, nos perguntamos o que levou os Vergueiro a adotar uma pobre criança bastarda como filha ?" (DO-5)

Bosi (2003) explica a necessidade que temos de identificar raízes, de construirmos nossa identidade a partir de um passado que nos garanta alguma identidade: 
"O movimento de recuperação da memória nas ciências humanas será moda acadêmica ou tem origem mais profunda como a necessidade de enraizamento? Do vínculo com o passado se extrai a força para formação de identidade".

(Bosi 2003:16, grifo nosso)

Em seu e-mail datado 30.03.2006, para José Eduardo Heflinger Jr., a Dra. Lotte Köhler escreve sobre um caráter um tanto religioso de religação e de construção de identidade familiar:

“...Eu gostaria de te contar a continuação da incrível história das memórias de infância da Carlota": Durante o lançamento do livro em Limeira, o professor Troppmair esteve presente e percebeu que seu avô, Augusto Brune, era irmão de Carlota. Então, ele comprou dois livros, enviou um à sua prima, Sra. Beckhaus, na Alemanha. Ela descobriu o número do meu telefone, entramos em contato, e descobrimos que duas outras bisnetas de Carlota estão morando nas vizinhanças da sua recém descoberta prima, e elas já se encontraram duas vezes e se acharam muito simpáticas. Augusto havia retornado ao Brasil e morrido muito cedo, e o contato com os parentes alemães desapareceu. Agora eles estão reconectados..." (tradução e grifo nosso)

As raízes do passado parecem garantir uma identidade na sensação dos corpos físicos que se reencontram, das almas psicológicas que revivem emoções e dos espíritos que vivenciam essa religação que reconstrói a identidade familiar; os vínculos biológicos de família são os primeiros a transmitirem a sensação de certeza de identidade de que necessitamos para lidar com nossa indeterminação e contingência, com nossa crise existencial de identidade.

\subsection{Reconstruindo Identidades em Comunidades de Prática}

Bosi (2003) continua a nos fornecer pistas para a compreensão da nossa necessidade de enraizamento e de construção de identidade, agora coletivas: 
"Parece que há sempre uma NARRATIVA COLETIVA privilegiada no interior de um mito ou de uma ideologia. E essa narrativa explicadora e legitimadora serve ao pode que a transmite e difunde".

(Bosi 2003:17, grifo da autora)

Havíamos confirmado a existência da narrativa nacional progressista nos empreendimentos ideológicos da Vergueiro \& Cia., nos ideais positivistas tanto europeus quanto brasileiros.

"Há, portanto uma memória coletiva produzida no interior de uma classe, mas com poder de difusão, que se alimenta de imagens, sentimento, idéias e valores que dão identidade àquela classe".

(Bosi 2003:18)

Como discutimos anteriormente (2.6.a), sob a perspectiva sócio-construtivista, a narrativa é uma construção de significado para o narrador e para a comunidade que flui, compartilhando das mesmas crenças por algum tempo, são as comunidades de prática de Lave (1997 em 2.5) com suas ações significativas dentro de certo sistema cultural. São as trajetórias de vida conduzindo sujeitos e identidades, construindo continuidades através da participação em eventos e em atividades distintos.

Dando continuidade à história/estória vivenciada pela comunidade pesquisada, José Eduardo Heflinger Jr., do Projeto Imigração Resgate, diretor da Sociedade Pró Memória de Limeira, editor da revista Povo há 22 anos, autor de 16 livros, editor de 30 livros, ex-secretário adjunto da Cultura, Turismo e Eventos de Limeira, foi convidado a retornar à Europa em Maio de 2006, para palestras no Centro de Língua Portuguesa / Instituto Camões da Universidade de Hamburgo, no German Immigration Center em Bremerhaven e na Universidade de Ciências Aplicadas de Bremen, retornando ao Brasil com um novo diário de Carlota Schmidt e com documentos sobre a repercussão européia da sublevação de Davatz. Lançou o Projeto Memória Limeirense a 8 de Junho de 2006, em parceria com a Secretaria da Educação no anfiteatro do ISCA Faculdades em Limeira, com o apoio das prefeituras de Limeira, Cordeirópolis e Iracemápolis, que capacitará docentes para o ensino da história da 


\section{imigração européia e do povoamento que deu origem a Limeira para 25} mil alunos da rede municipal. Fica claro o caráter de construção de identidade nacional a partir do reconhecimento internacional do direito de narrar. Heflinger Jr. explica que o objetivo do Projeto Imigração Resgate é o cruzamento dos dados contidos nos documentos originais do século XIX, principalmente que estão nos arquivos de Alemanha, Suíça, Portugal e Brasil.

Discutimos com Hall (1997 em 2.7.a) que as velhas identidades que estabilizavam o mundo social dão lugar ao sujeito fragmentado e que a idéia de uma essência interior foi sendo substituída pelo conceito de performatividade e de identificação. Notamos que o próprio Senador Vergueiro e seu filho Comendador José Vergueiro já tinham identidades contraditórias, que deslocam continuamente nossas identificações e que, até os dias de hoje, as teias narrativas de significação e de construção de identidade em volta dos acontecimentos acionados pela performatividade desses dois sujeitos continuam a se multiplicar. Nosso eu-performativo está inserido nas concepções da crítica anti-essencialista étnica, racial e nacional da identidade cultural e política local, e a questão de identidade recorre na tentativa de rearticular a relação entre sujeitos e práticas discursivas, entre a política de exclusão e a questão da identificação. Identidades são estratégicas e perspectivistas; estão em constante processo e transformação e, apesar de invocarem uma origem em um passado histórico, na prática lidam com questões de utilizar os recursos da história, da linguagem e da cultura.

A seguir, analisaremos algumas das falas de autoridades públicas locais e nacionais que construíram narrativas acerca do projeto, em torno da identidade Limeirense e Brasileira durante o evento de lançamento do Projeto Memória Limeirense. Exerceram o direito de narrar, o direito de enunciar:

Rupertus Von Morr - Cônsul Geral da Alemanha em SP

Giambatista Mondada - Cônsul Geral da Suíça em SP

Rudolf Shallenmuller - Cônsul Honorário da Alemanha em Ribeirão Preto

Elsa Sofia Tank - Presidenta da Câmara Municipal de Limeira

Mohamed Habib - Pró-reitor da Unicamp 
Gilberto Vasquez - Representante do prefeito de Limeira

Maria Cristina dos Santos -Diretora do Isca Faculdades de Limeira

Antonio Montezano Neto - Secretário da Educação de Limeira

Heflinger Jr. inicia com as falas:

- "O Projeto Memória Limeirense realmente não pretende fazer, nos seus livros, filmes, DVDs, um trabalho de cruzamento bibliográfico, onde nós temos aí uma porção de dados contidos em livros... Eu sei muito bem que papel aceita qualquer coisa, então nós resolvemos, por bem, contando com o apoio destas entidades, de muitos parceiros que estabelecemos agora em Europa, que estão enviando documentos pra gente sem parar... Nossa Limeira hoje, realmente a internacionalidade em sua história é reconhecida nas grandes universidades alemãs, suíças e também lá em Portugal, onde tivemos esses parceiros e imigrantes que vieram pra cá em meados do séc. XIX..."

- "Jamais imaginei, por exemplo, que o Nicolau de Campos Vergueiro, proprietário da fazenda Ibicaba, aquele que foi membro da Regência Trina Provisória, deputado, senador e o mentor da imigração particular em todo o Brasil, ele colocasse o negro Manoel pra tomar conta de sua propriedade, isto em 1822 consta no censo de Piracicaba...

... a importância do Isca, da UNICAMP, de toda casta de estudantes, professores, doutores, vão se envolver com esta história e tenho certeza que nós vamos crescer com isto, nós precisamos conhecer a nossa história porque um povo desenvolvido conhece sua história...

... a importância que os alemães, que os suíços e que os portugueses dão à história é muito grande, eles preservam, você vai aos castelos, você vai às cidades

...e aqui nós temos fazendas históricas maravilhosas, muita gente diz, isso é coisa de sonhador e tal, mas não é, aliás, esses cônsules aqui presentes, o Sr. Rupertus Von Morr, da Alemanha, e o Sr. Giambatista Mondada, da Suíça, e também a Fundação Martius Staden estão fazendo uma gestão para que a gente possa fazer um museu numa das 
fazendas históricas... Aliás, isso é um trabalho magnífico e essa é que é a grande vantagem, é que a gente possa valorizar o que é nosso, pra que a gente possa chamar pessoas pra visitar esse pedaço do séc. $X I X$, por onde foi deixado um rastro dos imigrantes, que eles estão ajudando pra que a gente possa preservar." (DO-6, grifos nossos)

Detectamos em Heflinger Jr. a consciência de que tudo que se coloca no papel é uma construção da realidade; no entanto este parece não diferenciar o fato de que tanto cruzamentos bibliográficos refraseados, perpetrados pela academia, quanto documentos ditos históricos são construções de significação registradas no papel. Notamos o salto que Limeira parece dar em sua identidade, ao exercer o direito de narrar, ao ter sua versão da realidade reconhecida internacionalmente por aqueles que dominam o direito de narrar. Em caráter nacional, o direito de criar uma narrativa reconhecida internacionalmente reitera a identidade nacional, assim, permanecem os valores liberais de progresso, embora $O$ Senador Vergueiro aparentemente racista, paradoxalmente, tenha ousado confiar sua fazenda a um negro.

- Heflinger Jr.: "A Câmara Municipal também resolveu apoiar o projeto e oferecer uma placa pra cada um desses cônsules por iniciativa da sua presidenta Elsa Tank por nos ajudarem a divulgar e a buscar um pouco mais os documentos da historia".

(DO-6)

- Elsa Tank (presidenta da Câmara): "Limeira precisa mesmo contar sua história para nossos filhos e nossos netos" (DO-6)

Representando o reitor da UNICAMP, Tadeu Jorge, o pró-reitor de Extensão e assuntos comunitários Habib declarou:

- "Nos entendemos na academia, que se nós não preservarmos e resgatarmos a memória da historia, nós teremos bastante dificuldade de valorizar o nosso presente e teremos mais dificuldade ainda de planejar o nosso futuro. Então a história, o 
passado, a memória, é um patrimônio que precisa ser sempre preservado...

... Nós já estamos construindo o novo campus da UNICAMP aqui em Limeira para abrigar um monte de cursos, inclusive um desses cursos é diretamente ligado à questão do patrimônio histórico... Então, a UNICAMP é uma instituição bastante comprometida com o resgate e com o registro da memória e da história da nossa sociedade brasileira, aproveitando enquanto ainda o Brasil é jovem e a história ainda está em nossa memória, precisa ser registrada, A UNICAMP sente-se bastante honrada de estar aqui hoje." (DO-6, grifo nosso)

Percebemos que a importância concedida à construção de identidade nacional ocorre nas diversas castas sociais, tanto na academia quanto na política e, também, popularmente. Conforme explicamos com Hall (1997 em 2.7.b), a identidade nacional tem o poder de conceder a ilusão de pertencimento, de que fazemos parte de uma identidade maior, de que - certamente - temos alguma identidade. Não nascemos com as identidades nacionais, elas são "formadas e transformadas no interior da representação". Nações são comunidades simbólicas e, portanto, têm poder para gerar sentimentos de identidade e de lealdade.

Representando o prefeito de Limeira e em nome da Secretaria de Desenvolvimento, Gilberto Vasquez parabenizou o evento e enfatizou o significado do resgate da memória para o momento atual e para o futuro:

- "...ao Toco que proporcionou que se reunissem as pessoas de maior cultura e de maior empenho desse município, de estar todos juntos reunidos numa sala, aqui hoje. Toco, o que você conseguiu, os senhores cônsules conseguiram, todos unidos conseguiram, vai ficar na história de Limeira e na história do mundo muito mais do que esses fatos que ocorreram há 100 anos, porque nós temos câmeras digitais, temos muito mais recursos pra se gravar tudo isso e a história vai dizer do que foi feito em Limeira nesse período por essas pessoas que estão resgatando a nossa história e vai levar a nossa cultura, o 


\section{nosso desenvolvimento para as crianças e para as futuras gerações..." (DO-6, grifo nosso)}

Com Derrida (1978 em 2.3), concluímos que as culturas ocidentais se gabam de ser escritas, mas são fonocêntricas, que o texto congela a fala e a escritura passa a ser o momento máximo da manifestação do pensamento, da origem, da presença, registrada no papel, mas o significado é adiado, pois, sendo contingente, não há garantia e depende da interpretação e do contexto. Até mesmo a moderna tecnologia, que nos possibilita a gravação de imagens e o registro da fala, tem por trás dela seres humanos narrando verdades vivenciadas, construindo, desconstruindo e reconstruindo processos de significação e de identidades. Conforme Lemke (1997 em 2.5), tanto identidades quanto sujeitos se estendem por trajetórias de vida, construindo continuidades através da participação em eventos distintos e em atividades diferentes.

A identidade do pesquisador José Eduardo Heflinger Jr. flutua entre o nome sócio-histórico acadêmico e a identificação popular e íntima como Toco, rompe a fronteira entre os saberes. Percebemos a presença do aqui e agora performativo e emergente na fala de Vasquez, e ao modo de Bosi:

\footnotetext{
"A narrativa é sempre uma escavação original do indivíduo, em tensão constante contra o tempo organizado pelo sistema. Esse tempo original e interior é a maior riqueza de que dispomos".
}

(Bosi 2003: 66)

Ela discorre sobre o trabalho persistente dos historiadores que, em casos como o de Toco, não conseguem resistir ao apelo da pesquisa:

"Os historiadores são como surdos, dizia Tolstoi, respondem perguntas que ninguém lhes fez".

(Bosi 2003:67)

Para a autora, a vivência contextualizada do narrador concede algo de transcendente ao caráter da narrativa: 


\begin{abstract}
"O narrador é um mestre do ofício que conhece seu mister: ele tem o dom do conselho. A ele foi dado abranger uma vida inteira. Seu talento de narrar lhe vem da experiência: sua lição, ele extraiu da própria dor; sua dignidade é a de contá-la até o fim, sem medo. Uma atmosfera sagrada circunda o narrador".
\end{abstract} (Bosi 2003:91)

De acordo com Lakoff \& Johnson (1999 em 2.4.a), nossa experiência espiritual tem como parte principal a projeção empática imaginativa, segundo a qual conhecemos nosso ambiente, que é o local da nossa existência e da nossa identidade. A espiritualidade corporificada é mais que uma experiência espiritual, é uma relação ética com o mundo físico. Com Bakhtin (1988 em 2.5), notamos que é necessário integrarmos a vivência interior e a exterior, pois o funcionamento da consciência não pode ser reduzido aos processos que acontecem no interior do organismo vivo. Toco insiste e persiste nas respostas a perguntas não feitas, na sua vivência que transcende o corpo e a alma, que evidencia o espírito ao narrar:

- "Antes da fala final do secretário Montezano Neto, que é o grande mentor desse evento, eu gostaria de agradecer mais uma vez a todos vocês por estarem aqui presentes e também eu nunca deixo de colocar em risco, porque eu sei que numa comunidade de gente muito inteligente, muita sabedoria, o homem procura a sabedoria a vida toda, ele vai à escola, depois à universidade, ele se torna um professor doutor, se enche de muita sabedoria, muitos conhecimentos, no entanto todos esses conhecimentos não são suficientes pra vencer a morte e eu queria dividir com vocês o grande segredo de se vencer a morte, porque quando o homem foi criado, ele foi criado com faculdades como nós todos temos e ele teve escolha de viver experimentando a pessoa de Deus e Seu Ser e resolveu viver por si mesmo, agir por si mesmo e ter o conhecimento do bem e do mal em si mesmo e, na verdade, por isso morreu, porque se separou da Vida que ele tinha à disposição, a Vida pra viver e escolheu viver por si mesmo e morrer. Mas Deus o amou muito e se fez como homem na pessoa de Jesus, foi, experimentou a morte, venceu a morte e todo aquele que Nele crê e não 
vai à igreja e não cumpre religiosidade, não é disso que eu estou falando, porque não estou convidando vocês pro culto da semana que vem, eu estou dizendo que o Deus vivo se fez carne e lá na cruz, aquela coisa tão simples, que é loucura para os sábios e um escândalo para aqueles que querem enxergar alguma coisa do amanhã ou do pra sempre, aquele que crê em Jesus, sabe que Ele pagou por ele, tem a vida eterna, é isso que eu desejo a vocês, que vocês creiam e Deus vos ilumine pra crer, muito obrigado." (DO-6, grifo nosso)

Percebemos que Toco, apesar de estar inserido naquela casta de pessoas que fazem e acontecem para definir a identidade nacional, em termos de uma ideologia, não acredita realmente que exista solução para o homem via o conhecimento humano; a consciência da morte faz com que ele se volte para uma solução transcendental, a resolução para o complexo de identificações que mascaram a falta de identidade seria solucionada espiritualmente via fé no Salvador Jesus Cristo, capaz de resgatar a humanidade do caos, por este ser o próprio Deus.

Na carta que o apóstolo Paulo escreve aos hebreus no Novo Testamento, este explica o funcionamento da fé, enquanto meio de comunicação transcendental para além do materialismo lógico racional que caracteriza nossos pensamentos de corpo e alma, pensamentos intelectuais, sensoriais e emocionais; até mesmo quando procuramos ter alguma consciência espiritual, mascaramos a falta de identidade ao criarmos deuses, religiões, mitos e ritualística. Ao curarmos doenças do corpo e doenças psíquicas, será que curamos a falta espiritual que sentimos? Se houvesse um Deus, será que Ele necessitaria das construções e das interpretações humanas em Seu nome, para efetivar a comunicação, para dar um significado à existência? Aqui e agora, constantemente nos iludimos com o poder de criarmos um complexo de identidades para energizar a falta.

"Ora, a fé é o firme fundamento das coisas que se esperam e a prova das coisas que se não vêem". (Hebreus 11:1) 
Segundo Ricouer (1977), explicar as múltiplas funções do significar humano não é tarefa fácil:

\begin{abstract}
"Estamos hoje em dia a busca de uma filosofia da linguagem capaz de explicar as múltiplas funções do significar humano e suas relações mútuas."

(Ricouer 1977:15)
\end{abstract}

Precisaríamos de uma filosofia da linguagem capaz de transcender a psique interpretativista humana que, constantemente, busca uma nova alternativa para lidar com o duplo sentido, para a falta gerada pela crise identitária.

\footnotetext{
“...Não há símbolo sem interpretação, onde quer que um homem sonhe, profetize ou poetize, outro se ergue para interpretar. A interpretação pertence organicamente ao pensamento simbólico e a seu duplo sentido." ～(Ricouer 1977:26,
} grifo nosso)

O autor se pergunta sobre o duplo sentido, que poderia ser dissimulação ou revelação, mentira ou acesso ao sagrado, e reitera que a fé é o contrário da suspeita, embora seja uma fé racional devido à interpretação, permanece como fé ao procurar, através da interpretação, uma segunda ingenuidade. O "círculo hermenêutico" é o crer e o compreender.

\footnotetext{
"De um lado, o sagrado está ligado a suas significações primárias, literais, sensíveis: é o que constitui sua opacidade, a significação literal está ligada pelo sentido simbólico que nela reside: é o que chamei de poder revelando símbolo, o qual constitui sua força, apesar de sua opacidade." (Ricouer 1977:36, grifo do autor)
}

Segundo Jung (1964), quando nossa mente explora um símbolo encontra idéias fora do alcance da nossa razão, nunca percebemos plenamente uma coisa, nem a entendemos por completo:

\footnotetext{
"Podemos sofrer dissociação e perder a identidade, podemos ser dominados e perturbados por nossos humores, fingimos ser capazes de nos controlarmos, mas o controle de si mesmo é
} 
virtude das mais raras e extraordinárias, a unidade da consciência pode ser facilmente rompida."

(Jung 1964:25, grifo nosso)

O poder simbólico exerce um enorme fascínio no campo da interpretação, a ilusão é um grande prazer, somos obstinados e temos uma vontade teimosa, a pretensão de, como deuses, exercermos o direito de renarrar. A sede por paradigmas, ao modo de Bourdieu (1996 em 2.7.b), apenas mascara a ausência de fatos tangíveis. Será que o acúmulo de conhecimento chega, sequer, a se assemelhar a experiências energéticas espirituais? Será que nosso pensamento social e cultural é suficiente para compreendermos o universo natural e transcendental? Para exercermos o papel de narravintes é preciso nos despojar da nossa soberba, do amor próprio e da exaltação de nós mesmos. Transformar não é adequar-se exteriormente, como muitas vezes somos obrigados a agir socialmente, o que fica mais evidente na condição de imigrantes; mas, todos nós chegamos a acreditar que temos, realmente, as identificações que assumimos e que estas são nossa identidade e, assim, vivemos de crise em crise, sem nenhuma certeza.

Conforme explica Bosi (1994), nossa tentativa desesperadora em relermos um passado e em encontrarmos raízes para reconstruirmos nossa identidade sempre, e com maior garantia, apenas ressalta a crise atual interpretativista que altera significados:

\footnotetext{
"A experiência da releitura é apenas um exemplo, entre muitos, da dificuldade, senão da impossibilidade, de reviver o passado tal e qual; impossibilidade que todo sujeito que lembra tem com o historiador. Para este também se coloca a meta ideal de refazer, no discurso presente, acontecimentos pretéritos, o que, a rigor, exigiria se tirassem dos túmulos todos os que agiram ou testemunharam os fatos a serem evocados. Posto o limite fatal que o tempo impõe ao historiador, não the resta senão: reconstruir, no que the for possível, a fisionomia dos acontecimentos. Nesse esforço exerce um papel condicionante todo o conjunto de noções presentes que, involuntariamente, nos
} 
obriga a avaliar (logo, a alterar) o conteúdo das memórias."

(Bosi 1994:59, grifo da autora)

Dando continuidade à reconstrução e releitura da memória social limeirense, o secretário da educação Antonio Montezano Neto declarou:

- “...eu sempre me lembro quando era criança que a gente ouvia dos familiares, ouvia, na rua, que o brasileiro não tem memória, que o brasileiro não tem história, e isso sempre me deixou muito triste, porque meu pai era italiano, e eu me lembro do meu pai sentado com a gente, e naquela época não tinha nem mesmo televisão, e ele me contava da Itália, da família dele, e eu percebia que ele tinha um conhecimento muito profundo das suas raízes, e eu pensava, puxa vida, porque que nós não podemos ser assim também...

...e eu tive a felicidade de estar a frente da secretaria da educação e a gente resolveu que iria incentivar os nossos alunos, os professores a estudar a história do município, mas, infelizmente, uma das maiores dificuldades é que nós não temos bibliografia, temos pouca coisa, e pouca gente tem acesso a essas informações que ainda algumas poucas pessoas guardam consigo...

...fiquei muito entusiasmado quando o Toco nos procurou e já veio com o livro pronto e falou: agora a gente pode aprofundar muito mais isso tudo... Ora, se ele está recebendo apoio da comunidade internacional, seria uma injustiça se nós não lhe dermos todo nosso apoio, então eu estou aqui para declarar o apoio do governo municipal...

(DO-6, grifo nosso)

Ora, o brasileiro é um povo aberto e receptivo às diferentes culturas; é um povo com aproximadamente 500 anos de história e de memória, não buscamos nossas raízes com a mesma facilidade com que povos mais antigos o fazem, a miscigenação cultural existente no nosso território propicia o reconhecimento do híbrido que busca o reconhecimento do direito de narrar sua identidade aprovado pela comunidade internacional, muito mais antiga. 
A atual crise interpretativista apenas escancara o hibridismo presente nas construções identitárias ao longo da história; antes, tínhamos a ilusão de significados puros devido a construções coletivas, hoje também, as construções coletivas, às quais temos acesso muito mais rapidamente devido à facilidade dos meios de comunicação, propiciam-nos perceber que, constantemente, convivemos com valores divergentes.

\begin{abstract}
Se examinarmos criticamente a meninice podemos encontrar nela aspirações truncadas, injustiças, prepotência, a hostilidade habitual contra os fracos. Poucos de nós puderam ver florescer seus talentos, cumprir sua vocação mais verdadeira. Comparamos acaso nossos ideais antigos com os presentes? Examinamos as raízes desse desengano progressivo das relações sociais? A criança sofre, o adolescente sofre. De onde nos vem então a saudade e a ternura pelos anos juvenis? Talvez porque a nossa fraqueza fosse uma força latente e em nós houvesse o germe de uma plenitude a se realizar."
\end{abstract}

(Bosi 1994:83, grifo nosso)

Os comentários de Bosi sobre a meninice nos conduzem, novamente, ao mito da língua-franca, à plenitude a se realizar, mas reitera que nossa fraqueza é uma força latente, uma falta, uma incompletude contingente, onde tudo pode se metamorfosear ou emergir performativamente.

Toco - Heflinger Jr. - continua sua façanha, ao conceder entrevista à TV Jornal de Limeira em 18/12/2006 - DO-7 - revelou outros aspectos da história que foram publicados em seu novo livro "Ibicaba: O Berço da Imigração Européia de Cunho Particular" que foi lançado a 27/06/2007 na fazenda Ibicaba em Limeira e a 01/08/2007 no Instituto Martius Staden em São Paulo. Na apresentação do livro, o Cônsul Honorário da República da Alemanha em Ribeirão Preto e Prof. Dr. da USP - Campus Ribeirão Preto, Rudolf Schallenmüler escreve: "Admiro em Heflinger seu espírito de "work in progress". Ele é um trabalhador da ciência histórica que "põe a mão na massa" dos documentos". 
Conforme discutimos com Cohen (1998 em 2.1), o procedimento "work in progress" carrega a noção de trabalho e de processo investindo na idéia de dinamicidade de sistema. Ainda com Kristeva (Lechte 1994), o "subject in process" está aberto a mudanças na personalidade pela experiência, formando sua identidade no seu processo de vida. O Projeto Imigração Resgate acaba de retornar (Outubro de 2007) de nova viagem à Europa, para dar continuidade às investigações acerca da imigração portuguesa, suíça e alemã de cunho particular e, também, investigar os italianos que foram os próximos a completar a lista de imigrantes que vieram ao Brasil, no século XIX. Voltou com uma série de novos documentos, entre os quais os registros de nascimento de Catharina Drenkhan e sua filha, que veio a se tornar Catharina Vergueiro. Encontrou e entrevistou os descendentes de Thomas Davatz, etc.

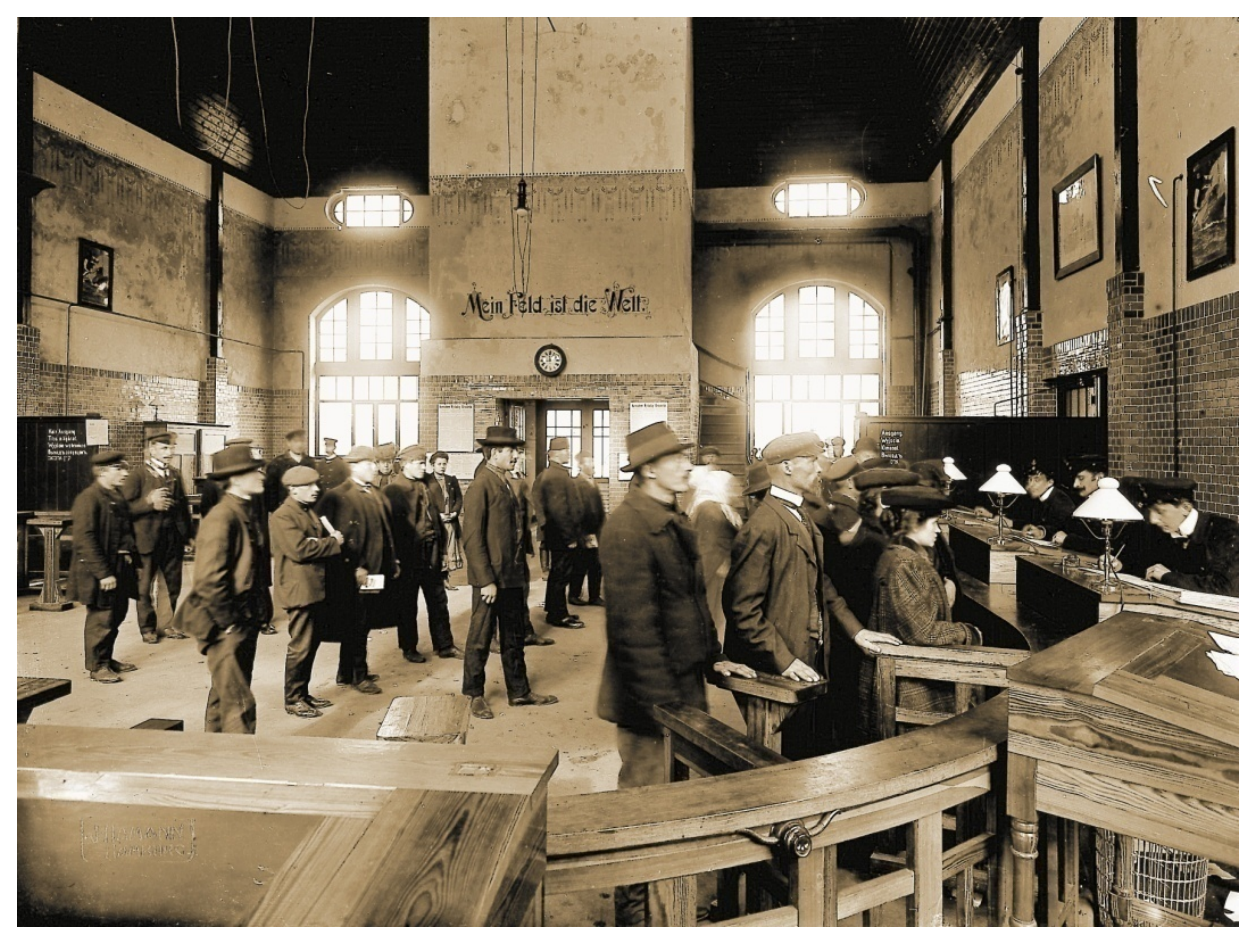

Atendimento do Departamento de Emigração no Porto de Hamburgo - Alemanha. Acervo: Link to Your Roots - Emigration Research Center Hamburg-de. 


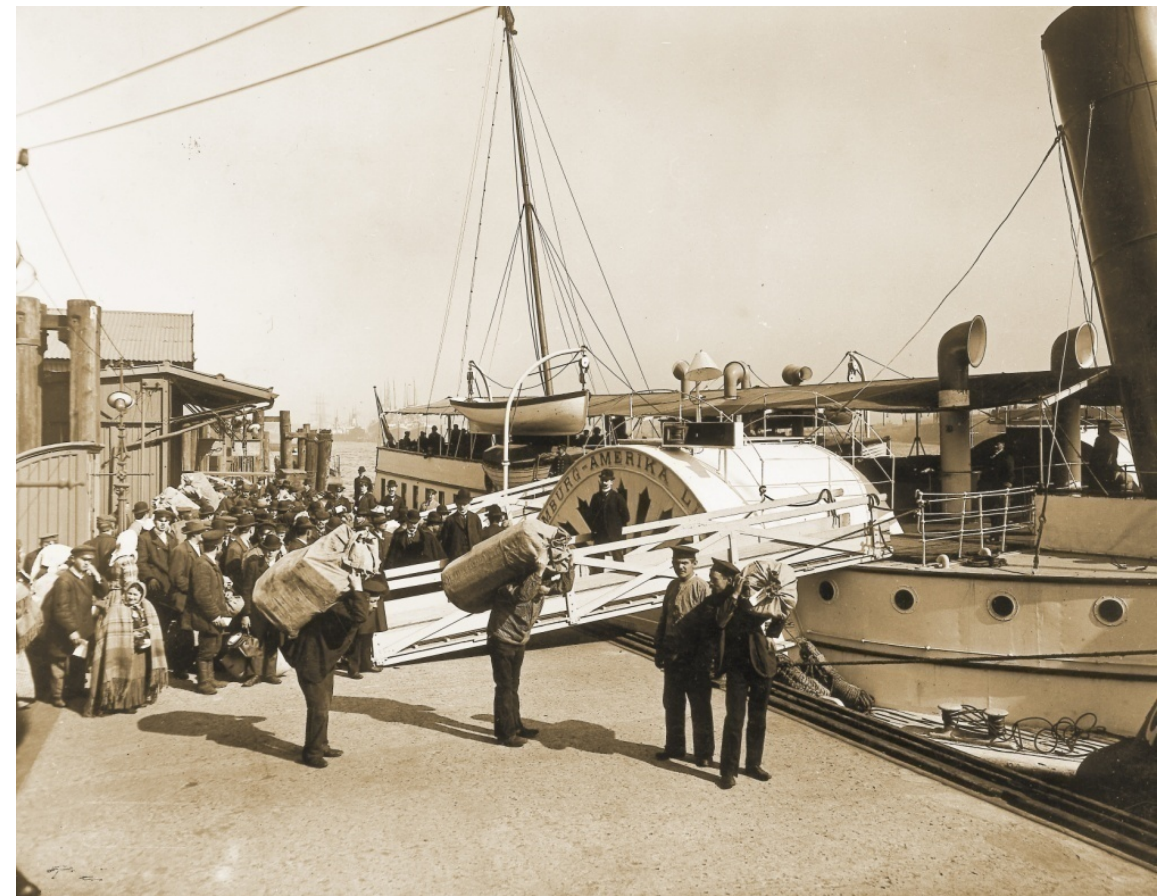

Porto de Hamburgo - Embarque de emigrantes, num dos navios da Hamburg Amerika Linie. Acervo: Link to Your Roots - Emigration Research Center - Hamburg - de.

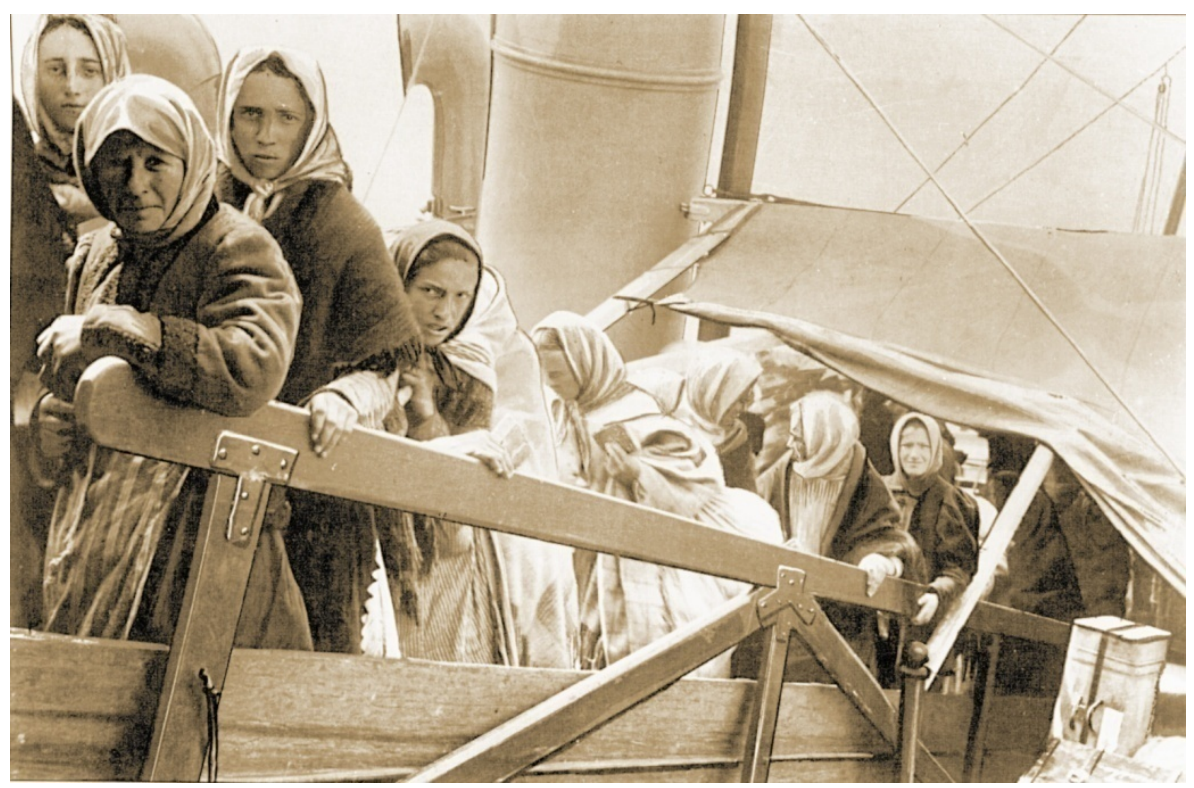

Embarque de emigrantes em Hamburgo - Hamburg Port of Dreams. Acervo: Link to Your Roots - Hamburgo. 


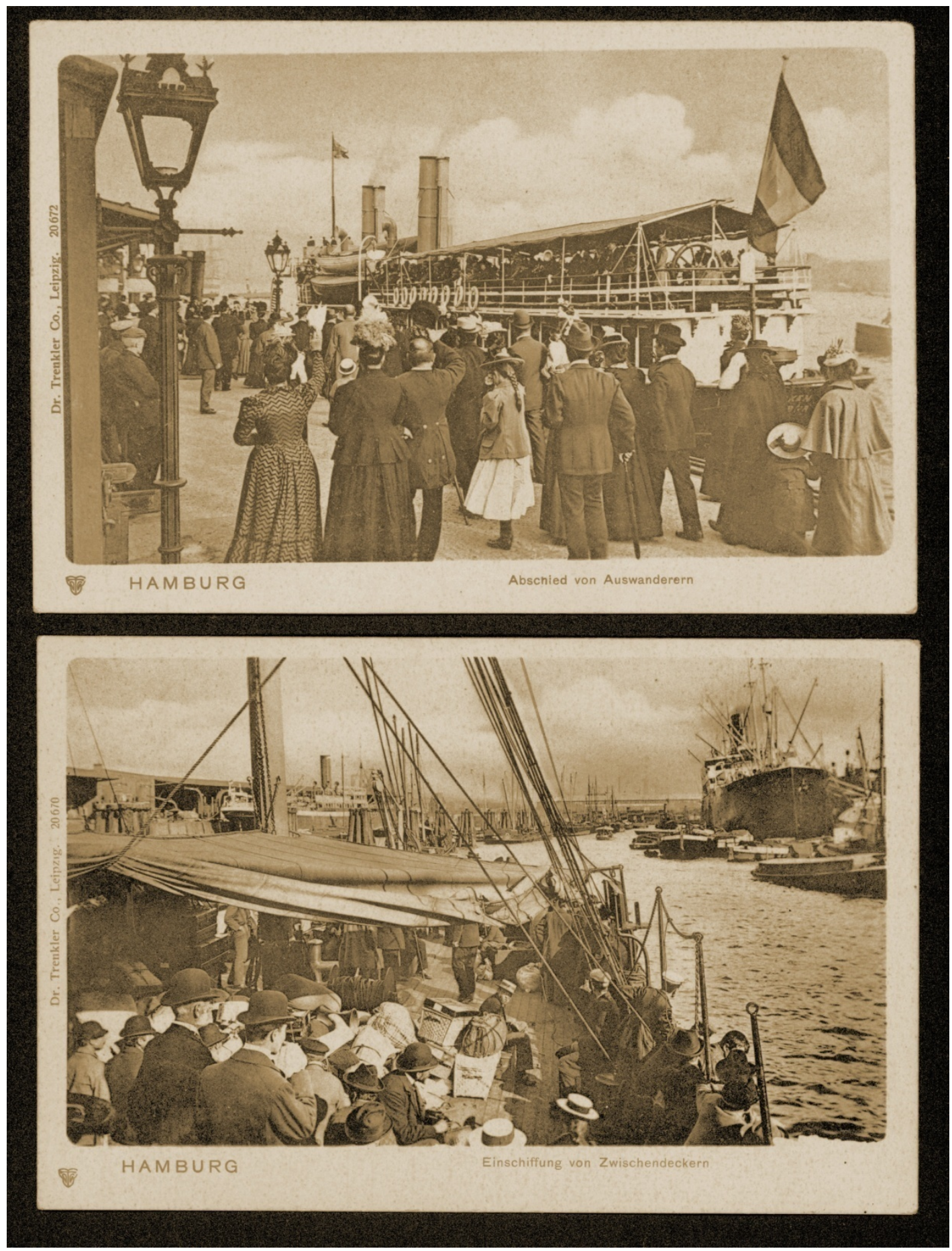

Despedida de emigrantes no Porto de Hamburgo - Alemanha.

Acervo: Link to Your Roots - Genealogical Research Center - Hamburg - de. 


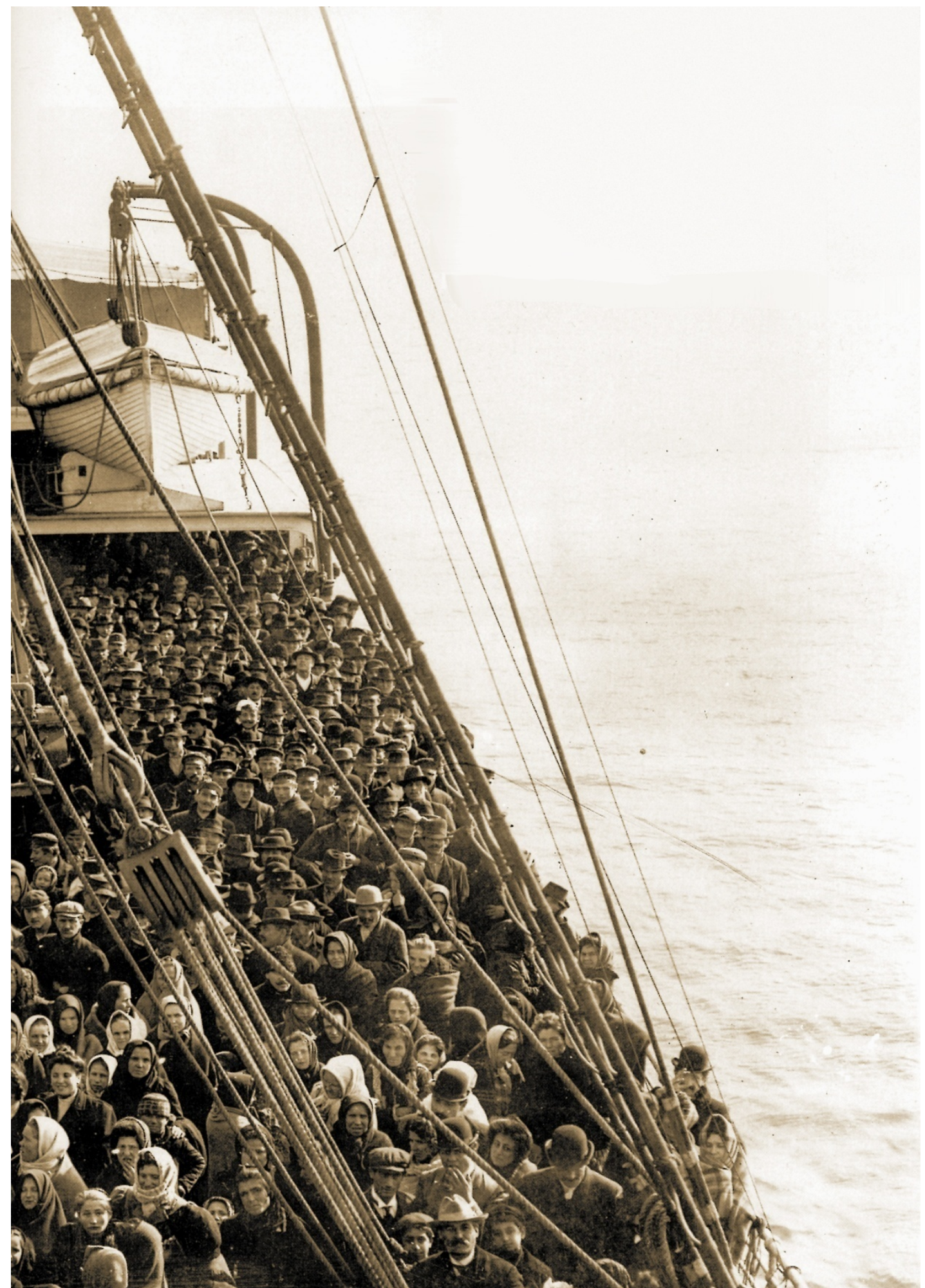

Porto de Hamburgo - Embarcação com emigrantes.

Acervo: Link to your Roots - Hamburg Emigration Research Service - de.

Ao refletirmos sobre a identidade fotográfica estampada nas fotos apresentadas nesse estudo, detectamos um forte contraste entre as fotos dos 
"donos da terra" e a dos "imigrantes", em nível da percepção simples, onde a relação indicada pelo corpo do outro inaugura uma diferença irredutível: entre o que se mostra e o que se esconde, percepção de imagem externa em imagem interna, conforme Gil (1997 em 2.4.c). A fotografia dos corpos revela a visão social sobre os fotografados, desde o tipo de roupa que vestem até o fato de serem identificados com os respectivos nomes. Por exemplo, os donos da terra vestem as melhores roupas e são identificados com os respectivos nomes e, caso algum funcionário apareça também na foto, seja sozinho ou acompanhado de outros funcionários e de crianças, esses vestem roupas similares às dos donos, para transmitir certa dignidade, mas não são nomeados. Já os imigrantes aparecem nas fotos sem identificação, sem nome, espalhados na multidão, vestindo roupas simples, ao passo que, quando estes alcançam status de donos, passam a ser nomeados e apresentam roupas distintas, como a garantir o hábito cultural e a posição social que detêm.

Transcrevemos abaixo alguns trechos significativos da entrevista de Toco à TV Jornal de Limeira em 18/12/2006:

- “Repórter 1 :...recebemos agora no Fatos e Notícias o idealizador do Projeto Imigração Resgate, o José Eduardo Heflinger Jr., mais conhecido como Toco... o projeto mudou um pouco o que nós conhecíamos sobre a história de Limeira, que era uma história muito marcada por lendas e mitos e você vem nos trazer, realmente baseado em documentos, aquilo que você foi buscar na Europa, você veio nos revelar detalhes, parte dessa história que o próprio limeirense não conhecia... um novo livro sendo escrito é essa a novidade? “

(DO-7, grifo nosso)

Com Derrida (1978), notamos que um documento histórico escrito é mais valorizado culturalmente que lendas e mitos narrados; com Bruner (1986, 2001), compreendemos que ambos são construções de significado perpetradas pelo homem. 
Toco:

- "Sim, é novidade até pra mim porque, na verdade, eu não conhecia a história pra ser sincero, quando você começa a encontrar documentos, você nunca pode dar como final aquilo que você sabe em história, porque a história é maquiada, é mentirosa, quem escreve a história são aqueles que os governantes pagam pra escrever... Então a visão que nós temos daquilo que realmente aconteceu, ela é totalmente equivocada... então eu vou só adiantar aqui, o filho do Senador Vergueiro, que deu a continuidade a partir de 1859, com a morte do senador, que foi o grande José Vergueiro, o Comendador que construiu o Caminho do Mar, teve um mandato de prisão contra ele e nós encontramos isso, ele foi morrer mais ou menos fugido da justiça num lugar chamado Xiririca, num lugar chamado Saudade, aqui no estado de SP...

...quando você não sabe a língua e tem que conseguir documentos históricos em alemão... Então... depende muito desse milagre maravilhoso que sempre acontece na vida daqueles que crêem, então o que aconteceu, eu peguei um documento tão raro que os alemães até agora não acreditam, falam como é que pode esse Zé conseguir os documentos que nós não encontramos nos nossos arquivos..." (DO-7, grifo nosso)

Com Foucault (1990), notamos em Heflinger Jr. a consciência de que o poder autoriza alguns segmentos da sociedade a narrarem sua versão da realidade e ele nos apresenta outra faceta da identidade de José Vergueiro, em outro contexto, em que, já destituído de glória, sofre com o abandono e com um mandato de prisão, vindo a falecer em um local ironicamente chamado Saudade, talvez com saudade de qualquer identidade. Toco reitera sua construção da realidade em torno dos milagres que circundam aqueles que têm fé e contam com a ajuda da energia divina como algo que interfere no andamento usual dos fatos determinados sócio-culturalmente, constrói sua identidade evidenciando questões espirituais no complexo de corpo, alma e espírito que está por trás da linguagem. 
- "Repórter 2: O Toco tem esse trabalho de resgate há muito tempo, já é o $16^{\circ}$ livro escrito pelo Toco e esse trabalho, como ele mesmo disse, vai contra a corrente do pré-estabelecido, por que é necessário, primeiro, recontar a história, Toco? E segundo, por que existem poucos que contradizem o estabelecido?"

Toco:

- "Porque é muito mais fácil você agradar aqueles que são os grandes papas da história do Brasil e, também, é muito mais fácil você ler e cruzar dados que já estão escritos, modificar um pouquinho aquilo e dizer que escreveu. Isso é fácil, agora você ir atrás do que está no gótico, está no documento histórico original em português arcaico, juntar tudo, cruzar toda essa documentação, verificar a autenticidade dessa documentação... por exemplo, olha que coisa incrível, você vai pra Portugal, ali procuramos em toda parte, eu li todos os documentos, todos os livros de saída dos imigrantes portugueses, não havia nada que constasse os nossos que chegaram aqui, que foram os primeiros a chegar, de repente, saímos em busca do material de polícia, daí começamos a entender que muita gente saía ilegalmente de lá e o sujeito que era o engajador do Vergueiro, que trazia o pessoal aqui pra nossa lbicaba e pra outros lugares do Brasil, porque ele também repassava os imigrantes para outros fazendeiros, ele trazia ilegalmente, porque ele saía pela porta do fundo, então ele trazia assassinos, ele trazia pessoas que haviam roubado, que tinham problema na polícia, meninos de 12 anos, e garotos que eram "premiados", o que que era isso?, "premiado" lá em Portugal significa, está engajado para o exército..."

(DO-7, grifo nosso)

Notamos, por parte do segundo repórter que entrevistou Toco, a percepção de que cada época reconta e reinterpreta sua história, reconstrói sua identidade, a partir do contexto que vivencia, seja através da descoberta de novos documentos, seja do questionamento das autoridades envolvidas nas versões anteriores. Toco questiona se, apenas, cruzar dados bibliográficos e reescrever a história justifica uma construção individualista de realidade, sem acrescer 
nada de, realmente, inusitado; no entanto, tal procedimento registra e confirma o hibridismo presente em cada cidadão comum, que reconta e reitera versões oficializadas para garantir alguma identidade, principalmente em âmbito nacional. Obviamente, torna-se mais complexo registrarmos versões que comprovam relações ilegais em determinados procedimentos, Nee (1989) pergunta: nós nos corrompemos quando produzimos ações desprezíveis, ou, também, quando produzimos atos de moral recomendável, cheios de boa intenção? Segundo o autor, a inteligência é inútil, a avidez pela verdade é também insuficiente, assim como a transmissão de conhecimento de uma mente para outra mente. Quanto conhecemos, realmente, da vida? Ou ela é simplesmente um produto da mente?

Conforme viemos explicando, a mente é um complexo de corpo, alma e espírito e a identidade é construção, interpretação contextual desse complexo em fluxo; conforme Bhabha (1994 em 2.7.c) somos todos híbridos, toda cultura e toda linguagem são híbridas no sentido de coexistir no terceiro espaço intersticial, onde os fundamentos não se sustentam, onde se realiza a tradução cultural, as ideologias são resignificadas no encontro com o outro.

Para sobreviver à crise de identidade, criamos identificações com nossas narrativas a respeito daquilo que vivenciamos: em primeira instância, algumas evidenciam o corpo e suas sensações, como as de Davatz ao descrever conflitos de adaptação física, biológica e cultural enfrentados pelos imigrantes que vieram ao Brasil, contrastando-os com vivências passadas; outras, em uma segunda instância, evidenciam pensamentos e sentimentos, como a vontade obstinada do Senador Vergueiro em obter um empreendimento de sucesso, inclusive com o apoio de várias narrativas políticas e intelectuais detentoras do poder, ou a vontade, também obstinada, dos Levy, em serem empreendedores, ambos com olhos para o futuro, ou, ainda, como as construções emotivas de Carlota Schmidt acerca do avô José Vergueiro e as de Lotte Köller acerca da família Vergueiro (poderíamos, também, citar a reconstrução da identidade limeirense e nacional sobrepondo todas essas narrativas vivenciadas); em terceira instância, detectamos narrativas que evidenciam questões espirituais, como a do pesquisador Toco. No entanto, 
todas essas narrativas são acionadas a partir de um complexo de corpo, alma e espírito, que vivencia, contextualmente, situações que tendem a valorizar de forma mais efetiva cada uma das partes deste complexo, a ponto de imaginarmos que não prescindimos das outras.

\section{INQUIETAÇÕES FINAIS}

Taylor discorre sobre um "elemento crucial na formulação da língua":

“...ela cria o tipo de afinidade peculiarmente humana, de estarmos juntos, de que nós estamos juntos na conversação. Expressar algo, formulá-lo, pode ser não apenas colocá-lo em foco articulado, mas também colocá-lo em espaço público, e assim unir-nos como co-participantes num ato comum de focagem.

...em princípio nossas formulações devem ser sempre capazes de ser formulações em comum . É por isso que elas são todas, em princípio, endereçadas aos outros, e aberta à crítica dos outros."

(Taylor 1985:275, tradução nossa)

Nossas formulações, nesta dissertação fazem parte do processamento de inquietações que permeiam o percurso de nossas vivências, simbolizam nosso momento performativo, são narrativas identitárias colocadas em espaço público e abertas à critica dos narravintes que se dispuserem ao diálogo e à tentativa de um ato comum de focagem, em busca de uma língua-franca.

Inicialmente, discutimos o caráter performativo da linguagem, sua flexibilidade e sua multiplicidade presentes no aqui e agora de nossa performance diária, ou seja, seu princípio de constante ação e reflexão. Um ato performativo desempenha o ato da fala como vivência da identidade, são representações performativas do sujeito. Nossa vivência da identidade, no dia-a-dia, é perpassada por inúmeras representações performativas do sujeito, ainda assim, ansiamos pelo mito da língua-franca.

Discorremos, a seguir, sobre a busca por uma língua-franca, que pudesse ser compreendida por todos e romper todas as fronteiras, integrar a mente - corpo, alma e espírito -, em uma comunhão total, onde linguagem e pensamento 
seriam unidos em um entendimento além da consciência como reflexo de nossa busca por uma identidade ontológica. Tal possibilidade persiste como uma sombra por trás de toda a linguagem, ou como um ideal a ser alcançado.

Dois momentos bíblicos, Babel e Pentecostes, lidam com essa nossa problemática que transita entre a multiplicidade e a unicidade de significado, de identidade, de ser e existir. Lidam com nossa necessidade de construir significados em comum, com o mito da transparência da linguagem, com a busca pela identidade. Lidam com a busca por uma língua-franca capaz de nos proporcionar uma comunhão espiritual, que é muito mais que o intercâmbio de idéias e opiniões, é a interação de mentes enquanto corpo, alma e espírito.

Enquanto seres viventes em constante processo performativo, em busca da nossa língua-franca, questionamos paradigmas constantemente, o complexo da nossa linguagem vai muito além da apenas falada ou escrita, envolve processos sinestésicos e cinestésicos de um corpo contextualizado e o sujeito por trás da fala não é apenas um corpo, ou um cérebro, mas uma mente corporificada que vivencia processos de significação de corpo, alma e espírito. Nossa comunicação performativa vivencia a interatividade e a emergência do fluxo deste complexo no aqui e agora contextual: ecológico, social, cultural (estético, ético e moral), econômico, político, religioso, que fazem parte da indeterminação e contingência de identidade.

Não existe saber desvinculado do contexto, tudo adquire um valor em um contexto: língua, cultura, natureza, tecnologia, afetividade, sentimento, depende da complexidade do valor que atribuímos. Contexto é a interconectividade desses elementos todos; semiose é o processo de construção de significado. Toda cognição é situada, fruto de um determinado lugar e contexto.

Prosseguimos a discussão, demonstrando como o modo narrativo da linguagem atua nessa vivência como processo de ação de construção de significação. A perspectiva sócio-construtivista considera narrar uma construção de significado para o narrador e para a comunidade, pois esta é 
fluída, sendo um grupo que compartilha das mesmas crenças durante algum tempo. Ao mesmo tempo em que nossas narrativas são negociadas com narrativas anteriores, ela é nosso processo de significação, liga elementos contingentes. No momento da leitura, o sujeito interpõe à narrativa o seu próprio horizonte cultural e de vida, o que dá margem a múltiplas interpretações do texto narrativo. Estudar a narrativa significa estudar a forma como os seres humanos vivenciam e representam o tempo e, também, como o homem vivencia e significa o próprio mundo, a própria vida.

Todos nossos mundos conceituais, caso considerados reais ou ficcionais, são criados em nossas mentes de acordo com certos padrões cognitivos. Experienciamos, continuamente, percepções mentais e sensoriais que moldam nossos mundos humanos de significação, selecionamos as que fazem sentido pra nossa busca existencial, as que nos garantem, teoricamente, alguma identidade e lutamos pelo direito de narrá-las, pelo direito de significar. O que está em jogo é o direito de buscar uma identidade através do ato de narrar, de narrarmos uma vivência, de vivenciarmos uma narrativa, o direito à busca existencial, ao significado da vida. A vivência contextualizada é o elemento de ligação entre narrativa e identidade.

$\mathrm{Na}$ falta de uma identidade fixa, vivenciamos uma crise de identidade e percorremos diversos processos de identificação, nos quais a ilusão de ter algo nos satisfaz por um determinado tempo e contexto. Demonstramos que rupturas ideológicas do mundo contemporâneo, como o marxismo, feminismo..., contribuíram para trazer à tona a crise de identidade, mas que ela sempre existiu, apenas persistia uma ilusão de realidades estáveis. Identidades são estratégicas e perspectivistas, estão sujeitas à historicidade radical, em constante processo e transformação.

Discutimos que a identidade nacional tem o poder de dar a ilusão de pertencimento, de que não estamos soltos na vida, nem à deriva, mas que fazemos parte de uma identidade maior e de que, portanto - certamente temos alguma identidade. Nossa identidade se metamorfoseia livremente, 
nossas identificações e construções nacionais em torno do tema apenas mascaram nossa indeterminação e nossa contingência, criamos uma teia de significações diante do medo de não encontrarmos significado algum para a nossa existência. Criamos uma teia de significação identitária para justificarmos nossa existência.

Explicamos que a hibridização não trata apenas da mistura de culturas, trata da luta pela autorização ou desautorização de uma determinada cultura. Percebemos que a questão do hibridismo, de convivermos com valores culturais diferentes, está presente em todos nós e é negociada em um terceiro espaço performativo onde os fundamentos colidem e trazem à tona nossa contingência e nossa indeterminação.

Assim como a crise de identidade e o direito de narrar, também o direito de significar, o direito de buscar um significado para nossa existência são mais facilmente detectados, e compreendidos, na situação do imigrante em busca de uma identidade nacional, embora, definitivamente, seja uma luta de todos nós. A falta é que propicia essa necessidade de instituirmos uma multiplicidade de paradigmas e uma teia de identificações, na ilusão ou na esperança de termos algo, de termos a presença, de alcançarmos nossa língua-franca.

Independente de discutirmos quem estava com a razão diante dos acontecimentos em torno da imigração de cunho particular, para a fazenda Ibicaba, no século XIX, ou ainda qual narrativa estaria mais próxima de uma possível "verdade", detectamos que várias "verdades" são construídas sóciohistórica e culturalmente, a partir de seus contextos em interação com seus momentos performativos e que 'as identidades são um complexo de narrativas vivenciadas, formadas nas zonas híbridas de encontro de culturas'.

O Senador Vergueiro (em torno de 1846) constrói os significados de sua identidade a partir de ideais positivistas e liberais que moldam grandes identidades nacionais em nome de um futuro progressista, como membro da elite nacional governista, a partir de sua posição de inclusão e 
pertencimento, tem seu direito de narrar garantido e suas construções da realidade apoiadas como verdadeiras.

Apesar da Marinha Inglesa (1844 - 45) estar investida de um poder econômico que autoriza suas declarações sobre a dúbia identidade de Vergueiro enquanto contrabandista de escravos, a identidade que prevalece é a de visionário empreendedor. A identidade progressista nacional tem maior peso e não parece haver qualquer preocupação com a identidade dos imigrantes que passam a ser uma força-de-trabalho.

$\mathrm{Na}$ comunidade abordada, narrativas de um determinado contexto social, munidas do direito de narrar que a posição social e o poder lhes concedem, são consideradas "verdades" e grandes narrativas da história, ao passo que outras, como a de Thomas Davatz (líder da sublevação em 1856), do ponto de vista do subalterno, tem valor menor; no entanto, notamos que, enquanto as primeiras podem ser desmentidas, as últimas, por sua vez, podem escalar os degraus da verdade social e serem consideradas oficiais. Ambas lidam com a indeterminação e a contingência, procurando garantir seus paradigmas através da ação emergente e performativa, propiciando a ilusão de que existe "alguma" verdade.

Davatz narra sua versão do ponto de vista do deslocamento, do incômodo de ser estrangeiro, expõe a identidade estratégica que passaram a vivenciar no encontro de culturas. Na posição de colonos oprimidos, as várias identidades podem passar a ilusão de uma identidade única, dependendo do contexto. O fato de existir o livro de Davatz, com sua versão polêmica sobre as colônias de parceria, com a narrativa de sua vivência dos acontecimentos, que foi aceito como expressão da verdade pelos governos europeus e que, por sua vez, proibiram a imigração para o Brasil (1859), prova o quanto é, também, tênue a fronteira entre verdades instituídas historicamente e verdades narradas. 
O Senador Vergueiro acreditava em seu empreendimento com visão futurista, expressando valores liberais positivistas da sua comunidade e da comunidade internacional, não tinha idéia dos conflitos culturais que estava criando até que o colono suíço Davatz, mestre-escola, pessoa culta, encarregada de descrever a situação para a comunidade européia, ao sofrer o choque que toda imigração propicia, ao perceber que a realidade não é transparente, trouxe alguns problemas à tona. Aquilo que é prioridade e certeza para uns, em outra cultura passa a ser duvidoso; para Davatz, que veio pelo sonho de "Fazer a América", era difícil não poder garantir sua identidade, era chocante verificar que, na verdade, poderia estar sendo um escravo branco do, segundo ele, ganancioso escravocrata Senador Vergueiro.

Os imigrantes que, aqui, chegaram vieram cheios de ilusões, também acreditavam no ideal progressista de sucesso, sem estarem preparados para o choque cultural de que seriam vítimas, na experiência do deslocamento não há volta. Daí um conflito num primeiro impacto, que transtorna a pessoa devido a sua performance e história social anterior, mas também a adaptação provém da mesma ação corpórea em um novo contexto. A interatividade entre o novo e o velho, nesta mesma pessoa, neste novo contexto, propicia uma importante troca performativa de experiências e de conhecimentos culturais diferentes. A cultura passa a ser um processo tradutório de constante resignificação enquanto estratégia de sobrevivência.

Ao sentir-se injustiçado, Davatz sabe a que autoridades recorrer para defender seus direitos, não age irracionalmente, procura obter o direito de narrar reconhecido pelas autoridades suíças e brasileiras. Ao consegui-lo, continua a manter a calma, mas a reação dos patrões quase causa uma rebelião armada que o próprio Davatz achou por bem conter. O mestre-escola suíço vinha de um contexto europeu onde se configuravam ideais democráticos, o que justifica sua construção da realidade. As reações bélicas do Comendador José Vergueiro, filho do senador e sócio da Vergueiro \& Cia., permite-nos compreender como interpretações diferentes de um mesmo 
acontecimento, quando munidas de maior poder narrativo, podem, eventualmente, mudar completamente a história caso se resolva acreditar nelas. Felizmente, o suíço Davatz também obteve resposta à suas reivindicações e foi um dos poucos a retornar ao país de origem, embora ele tenha retornado a seu espaço físico anterior, a experiência do deslocamento não tem volta, no sentido de não podermos apagar a vivência de valores culturais conflitantes.

Lidamos com nossa contingência e com nossa indeterminação identitárias através de um processo de ação emergente e performativo da nossa vivência contextualizada, na expectativa de garantirmos nossa construção de significação, seja ela a partir de uma posição de inclusão e de pertencimento, como as identidades nacionais, a exemplo do Senador Vergueiro, que tem seu direito de narrar garantido, seja a partir da posição de deslocamento e de incômodo da identidade estratégica que os imigrantes, a exemplo de Thomas Davatz, passam a vivenciar no encontro de culturas. Os primeiros lidam com o tempo com uma perspectiva ideal futurista, enquanto os outros se voltam para um passado que, apesar de não propiciar garantia alguma, tanto que o abandonaram, passa a ilusão de algum pertencimento.

Através do conceito de estrutura normatizador de cultura e de língua, poderíamos prever que os membros da Vergueiro \& Cia., que faziam parte da elite brasileira, construíssem significados a partir de conceitos positivistas e liberais, vigentes na maioria dos contextos do século XIX, até o conseqüente conflito que houve com colonos europeus que vivenciaram o deslocamento, 0 afastamento e o questionamento de valores. Mas, é através do conceito emergente e performativo de linguagem e de cultura que compreendemos não apenas as relações descritas acima, mas também a contingência e a indeterminação presentes nas identidades que fogem à regra.

Como exemplo de conflitos que não ocorrem, podemos verificar a performance da família Levy (chegada em 1857), cuja narrativa de sucesso reforça a identidade do Senador Vergueiro como a de um homem visionário e bem 
sucedido nacionalista. Esses colonos, apesar de serem de outra cultura, ao se depararem com a nova, trataram de abraçá-la, inclusive abrindo mão de sua religião, não vivenciaram a questão como imposição, mas como mediação, e adotam e enaltecem a visão de futuro dos Vergueiro. Chegam, inclusive, a comprar a fazenda dos patrões (1890) e, o importante, é narrar sua história de sucesso, comprovar sua identidade de ex-colonos abastados. A performance da família Levy, embora imigrantes, assumiu o espírito progressista e emergiu de acordo com as expectativas socialmente construídas pelo nacionalista Senador Vergueiro em seu empreendimento de contratar imigrantes de cunho particular, chegando até a superá-las por conseguirem igualar-se aos patrões. Diante do desempenho dessa família, vemos que a aquisição do direito de narrar, na escala social, muitas vezes, reforça grandes narrativas nacionalistas.

Dando seqüência às narrativas que compõem esta pesquisa, verificamos o direito de narrar adquirido pelas pequenas histórias diante da crise de identidade, Carlota Schmidt (nascida em 1875), neta do polêmico Comendador José Vergueiro, que em um ato de generosidade adotou a mãe dela, que era uma criança alemã (nascida em 1852), escreve suas memórias sem ter passado pela experiência do deslocamento e reforça o hibridismo presente em todos nós, no sentido de convivermos com valores diferentes que confrontados em um terceiro espaço não se sustentam. Identidade não é o que dizemos ser, mas o que o contexto produz: ela está distanciada no tempo dos acontecimentos históricos vividos por Davatz e os Levy, mas, por conviver com o avô José Vergueiro, filho do Senador, que esteve envolvido nos acontecimentos relatados e que, ainda, responde pela Casa Vergueiro, constrói a faceta da identidade deste a partir do lócus de enunciação e da vivência como neta amada gerada pela filha adotiva, julga-o importante, justo e bondoso.

No caso de Carlota Schmidt, o hibridismo social e cultural fica visível devido ao fato de ser filha de pais imigrantes alemães e neta da elite cafeeira brasileira, que é, também, escravagista e racista. Sua identidade sofre outra resignificação ao se deparar com o sofrimento de um negro e de se sentir traída por ele, pois, até então, achava que os negros eram seus amigos. Expressa valores de sua 
comunidade e não percebe que a atitude do negro, ao conquistar a compaixão dos netos do seu senhor implacável - que, para ele, era a tortura em pessoa -, valeu-lhe a tão preciosa liberdade e que, se este tivesse o direito de narrar sua vivência, provavelmente poderia convencer-nos de outras verdades.

Passamos, então, a analisar a teia de significação criada pelos acontecimentos bordados no nosso aqui e agora performativo, através de depoimentos orais, que abrem espaço para pontos de vista contraditórios poderem existir e exibem nossa sensibilidade e nossa mentalidade. A neta mais velha de Carlota Schmidt, a Dra. Lotte Köhler, médica psicanalista de 82 anos de idade, até a presente data (2007) residente em Munique, encontrou as recordações da avó e percebeu o pequeno tesouro histórico que possuía; conseqüentemente, tentou publicá-las e decepcionou-se com a falta de poder narrativo de que dispunha, até que o pesquisador José Eduardo Heflinger Jr. resolveu exercer seu papel de narravinte e de editor.

Apesar do seu lócus de enunciação enquanto psicanalista, demonstra espanto ao perceber o complexo de narrativas em torno da identidade da Casa Vergueiro, pois, para ela, "a história deste livro é um moderno conto de fadas", pois esta é sua construção de identidade a partir das narrativas familiares que herdou. A contemporaneidade e suas facilidades comunicativas permitiram à psicanalista lutar pelo seu direito de narrar "a verdade" no Johann Jacobs Museum, em Zurich, experimentando, em um curto espaço de tempo, a sensação de possuir o direito de narrar sua versão dos fatos e, imediatamente, de lhe ser tomado tal direito por, talvez, não corresponder aos interesses do poder vigente.

O hibridismo sempre esteve presente nas construções identitárias dos indivíduos ao longo da história, mas as versões oficiais escritas, presentes principalmente nos documentos históricos, costumam ser unilaterais e nem sempre permitem a percepção do complexo híbrido de identidades que constituem cada um de nós; apesar de sempre estarmos interpretando aquilo que lemos a partir de nossa vivência de significação, somos impelidos a assumir a versão do poder vigente. 
Detectamos, então, as conseqüências da obtenção do direito de narrar que Lotte adquiriu em parceria com José Eduardo Heflinger Jr. - do Projeto Imigração Resgate, pois o livro "Recordações de Infância de Carlota Schmidt no Ibicaba" foi lançado no mesmo Johann Jacobs Museum - Museu do Café, em Zurique, em 2005, que previamente havia recusado esta versão dos acontecimentos e passou a lhe conceder status de verdade, com a presença de autoridades representativas da identidade nacional e com a aprovação da comunidade internacional para palestras a respeito da nova visão da imigração.

Temos necessidade de identificar raízes, de construirmos nossa identidade a partir de um passado que nos garanta alguma identidade. $A$ partir de seu encontro com familiares, Lotte escreve sobre um caráter um tanto religioso de religação e de reconstrução de identidade familiar. As raízes do passado parecem garantir uma identidade na sensação dos corpos físicos que se reencontram, das almas psicológicas que revivem emoções e dos espíritos que vivenciam essa religação que reconstrói a identidade familiar, os vínculos biológicos de família são os primeiros a transmitirem a sensação de certeza de identidade de que necessitamos para lidar com nossa indeterminação e com nossa contingência; enfim, com nossa crise existencial de identidade.

Percebemos o poder de difusão presente na memória coletiva que, através de imagens, sentimentos, idéias e valores, dão identidade a uma determinada classe. As comunidades de prática fluem com suas ações significativas, compartilhando as mesmas crenças dentro de certo sistema cultural. Nossas trajetórias de vida conduzem sujeitos e identidades e constroem continuidades através da participação em eventos e em atividades distintos.

A comunidade atual em torno dos acontecimentos da fazenda lbicaba lançou o Projeto Memória Limeirense em 2006, em parceria com a Secretaria da Educação, com o apoio das prefeituras de Limeira, Cordeirópolis e Iracemápolis, que capacitará docentes para o ensino da história da imigração européia e do povoamento que deu origem a Limeira para 25 mil alunos da 
rede municipal. Fica claro o caráter de construção de identidade nacional a partir do reconhecimento internacional do direito de narrar.

Notamos que o próprio Senador Vergueiro e seu filho Comendador José Vergueiro já tinham identidades contraditórias que deslocam continuamente nossas identificações e que, até os dias de hoje, as teias narrativas de significação e de construção de identidade em volta dos acontecimentos acionados pela performatividade desses sujeitos continuam a se multiplicar. Identidades são estratégicas e perspectivistas, estão em constante processo e transformação; apesar de invocarem uma origem num passado histórico, na prática lidam com questões de utilizar os recursos da história, da linguagem e da cultura.

Foram gravados em DVD os depoimentos de várias autoridades públicas locais, nacionais e internacionais que tiveram o direito de construir narrativas acerca do projeto, em torno da identidade Limeirense e Brasileira durante o evento. Limeira parece dar um salto em sua identidade, ao exercer o direito de narrar, ao ter sua versão da realidade reconhecida internacionalmente por aqueles que dominam o direito de narrar. Em caráter nacional, o direito de criar uma narrativa reconhecida internacionalmente reitera a identidade nacional, assim, permanecem os valores liberais de progresso, embora ainda excepcionalmente, no depoimento de Toco, descobrimos que o Senador Vergueiro aparentemente racista, paradoxalmente, tenha inclusive ousado confiar sua fazenda a um negro. Percebemos que a importância concedida à construção de identidade nacional ocorre nas diversas castas sociais, tanto na academia quanto na política e, também, popularmente, gerando sentimentos de identidade e de lealdade.

A identidade do pesquisador José Eduardo Heflinger Jr. flutua entre o nome sócio-histórico acadêmico e a identificação popular e íntima como Toco, rompe a fronteira entre os saberes. A narrativa é uma construção original do indivíduo ao abranger uma vida inteira e carrega uma atmosfera sagrada. Percebemos que Toco, apesar de estar inserido naquela casta de pessoas que fazem e acontecem para definir a identidade nacional em termos de uma 
ideologia, não acredita realmente que exista solução para o homem via o conhecimento humano, a consciência da morte faz com que ele se volte para uma solução transcendental.

Em seu novo livro "Ibicaba: O Berço da Imigração Européia de Cunho Particular" que foi lançado em 2007, Toco - Heflinger Jr. nos apresenta outra faceta da identidade de José Vergueiro em outro contexto, em que, já destituído da glória, sofre com abandono e com um mandato de prisão, vindo a falecer em um local ironicamente chamado Saudade, talvez com saudade de qualquer identidade. Durante entrevista para a televisão, Toco reitera sua construção da realidade em torno dos milagres que circundam aqueles que têm fé e contam com a ajuda da energia divina como algo que interfere no andamento usual dos fatos determinados sócio-culturalmente, constrói sua identidade evidenciando questões espirituais no complexo de corpo, alma e espírito que está por trás da linguagem.

A atual crise interpretativista apenas escancara o hibridismo presente nas construções identitárias ao longo da história; antes tínhamos a ilusão de significados puros devido a construções coletivas, hoje também, as construções coletivas, às quais temos acesso muito mais rapidamente devido à facilidade dos meios de comunicação, propiciam-nos perceber que, constantemente, convivemos com valores divergentes. Nossa fraqueza é uma força latente, uma falta, uma incompletude contingente, onde tudo pode metamorfosear-se ou emergir performativamente.

Conforme viemos explicando, a mente é um complexo de corpo, alma e espírito e a identidade é construção, interpretação contextual desse complexo em fluxo; somos todos híbridos, toda cultura e toda linguagem são híbridas no sentido de coexistir no terceiro espaço intersticial, onde os fundamentos não se sustentam, onde se realiza a tradução cultural, as ideologias são resignificadas no encontro com o outro. Através do direito de narrar sob perspectivas, vivências e contextos distintos, sejam de inclusão ou deslocamento, sejam voltadas para o passado ou futuro, somos todos híbridos ao 
lidarmos com a indeterminação e com a contingência de identidade que é o que temos em comum.

Para sobrevivermos à crise de identidade criamos identificações, teias de significação com nossas narrativas a respeito daquilo que vivenciamos: em primeira instância, algumas evidenciam o corpo e suas sensações como as de Davatz ao descrever conflitos de adaptação física, biológica e cultural enfrentados pelos imigrantes que vieram ao Brasil, contrastando-os com vivências passadas; outras, em uma segunda instância, evidenciam pensamentos e sentimentos como a vontade obstinada do Senador Vergueiro em obter um empreendimento de sucesso, inclusive com o apoio de várias narrativas políticas e intelectuais detentoras do poder, ou a vontade, também obstinada, dos Levy em serem empreendedores, ambos com olhos para o futuro, ou, ainda, como as construções emotivas de Carlota Schmidt acerca do avô José Vergueiro e as de Lotte Köller acerca da família Vergueiro (poderíamos, também, citar a reconstrução da identidade limeirense e nacional sobrepondo todas essas narrativas vivenciadas); em terceira instância detectamos narrativas que evidenciam questões espirituais como a do pesquisador Toco. No entanto, todas essas narrativas são acionadas a partir de um complexo de corpo, alma e espírito que vivencia contextualmente situações que tendem a valorizar - de forma mais efetiva - cada uma das partes desse complexo a ponto de imaginarmos que não prescindimos das outras, que alcançamos nossa língua-franca.

Seria o Senador Vergueiro um visionário, mentor da imigração de cunho particular, um dos responsáveis pelo destaque econômico do Estado de São Paulo perante o Brasil, conforme a história oficial brasileira? Seria José Vergueiro filho e colaborador do grande Senador Vergueiro, o avô amoroso e cidadão exemplar capaz de adotar uma imigrante; ou ainda seriam ambos escravagistas desalmados, políticos corruptos que agiam ilegalmente no engajamento de imigrantes, conforme Davatz e os governos europeus? Davatz seria um anarquista ou um defensor de princípios democráticos? A família Levy, com sua história de sucesso, apóia os empreendimentos dos Vergueiro e, apesar dos conflitos trabalhistas entre fazendeiros e colonos imigrantes, os 
livros de registros da fazenda Ibicaba mostram que a grande maioria saiu da fazenda com posses.

Seria a história de Carlota Schmidt "um moderno conto de fadas"? Seria o pesquisador José Eduardo Heflinger Jr. um historiador nato, um dos mentores da construção da atual identidade limeirense e nacional ou uma pessoa que vivencia a fé? Não procuraremos responder a tais perguntas, pois o que nos interessa, aqui, é demonstrar que são construídas teias de significação, várias verdades, científicas ou não, sócio-culturalmente e ideologicamente contextualizadas, a partir de perspectivas diferentes, enquanto essencialismos estratégicos, e que tais construções são narrativas vivenciadas que compõem a identidade.

A conclusão a que chegamos é que estas seriam apenas algumas das diversas identidades ou identificações vivenciadas de corpo, alma e espírito, que convivem em negociação no terceiro espaço, onde as verdades são desconstruídas e confrontadas diante da performatividade, do direito de significar do outro, seja autor ou leitor, dominante ou subalterno, professor ou aluno. Ao modo de Spivak "can the subaltern speak?" (Kapoor 2004) perguntamos : pode o aluno narrar?

\section{BIBLIOGRAFIA:}

* Bakhtin, M. 1981 The Dialogic Imagination, Austin, University of Texas Press

1992 Estética da Criação Verbal, São Paulo, Martins

Fontes

(Volosinov) 1988 Marxismo e filosofia da linguagem, SP, Ed. Hucitec

* Baudrillard, J. 1999 A Troca Impossível, Rio de Janeiro, Nova Fronteira 2002. 
* Bauman, Z. 1987 Legislators and Interpreters, Cambridge, Polity Press

* Bezerra Jr., 1997 Corpo, Afeto, Linguagem, Lisboa, Relógio D’Água. Rio de Janeiro, Rios Ambiciosos, 2001.

Bhabha, H. (org.) 1990 (a) Nation and Narration, London, Routledge 1990 (b) The Third Space em Rutherford 1990 1994 The Location of Culture, Routledge. 1998 “Culture's In Between" In Bennett(ed),

Multicultural States, New York, Routledge. 2000 (b) Minority Culture and Creative Anxiety, em http://www.britishcouncil.org/studies/reinventing britain/bhabha : acesso em 2000 2001 Interview with Homi Bhabha by Kerry Chance $3 / 19 / 01$

* Bosi, E., 1994 Memória e Sociedade, São Paulo, Companhia das Letras. 2003 O Tempo Vivo da Memória, São Paulo, Ateliê Editorial.

Bourdieu, P. 1994 Academic Discourse, Polity Press, Cambridge 1996 A Economia das Trocas Lingüísticas, São Paulo, Edusp

* Bredo, E. \& Feinberg, W., 1982, “The Positivistic Approach to Social and Educational Research" in Knowledge and Values In Social Educational Research, Philadelphia, Temple University Press

Brockmeier, J. \& Harré, R. Narrativa: problemas e promessas de um paradigma alternativo, disponível em: http://www.scielo.br/scielo.php?script=sci arttext\&pid=S0102797220030 00300011\&lng=en\&nrm=iso : acesso em outubro 2005 
* Bruner, J. 1986 Actual Minds Possible Worlds, Cambridge, Harvard University Press

2001 A Cultura da Educação, Porto Alegre, Artmed 1992 Acts of Meaning, Harvard

* Bruner, E. M. 1986 "Experience and its Expression" in Turner, V.W. and Bruner, E. M. (eds.) The Anthropology of Experience, University of Illinois Press.

Busch, R. K. 1967 História de Limeira, $1^{\circ}$ volume, Limeira, 2a edição do autor.

* Butler, C., 1984, Interpretation, Deconstruction and Ideology, Oxford, Claredon Press

Butler, J., 1990, Gender Trouble, London, Routledge

* Cohen, R. 1998 Work in Progress na Cena Contemporânea, São Paulo, Perspectiva.

2002 Performance como Linguagem, São

Paulo, Perspectiva.

* Csordas, T. J. (ed.) 1994 "The Body as Representation and Being-inthe-world" in Embodiment and Experience: The Existential Ground of Culture and Self, Cambridge, Cambridge University Press.

Davatz, T. 1850 Memórias de um Colono no Brasil, São Paulo, Martins, Editora da Universidade de São Paulo, trad. Sérgio Buarque de Holanda, 1972

Derrida, J. 1974 Of Grammatology, Baltimore, John Hopkins Press 1978 Writing and Difference, UK, The Gresham Press

Descartes, R. 1987 Meditações 
* Forjaz, D. 1924 O Senador Vergueiro, São Paulo, Officinas do "Diário Official".

* Foucault, M. 1987 A Arqueologia do Saber, Forense Universitária, Rio de Janeiro 1990, Microfísica do Poder, RJ, Graal

* Garcia, A. N. 2004 Democracia Semidireta: Referendo, Plebiscito, Iniciativa Popular e Legislação Participativa, disponível em http://www.senado.gov.br/sf/senado/unilegis/pdf/UL_TF_DL_2004_ALEX ANDRE_NAVARRO_GARCIA.pdf

* Geertz, C. 1997 O Saber Local, Editora Vozes, Petrópolis 2000 1973 The Interpretation of Cultures, Basic Books

* Gil, J. 1997 Metamorfoses do Corpo, Lisboa, Relógio D’Água.

* Gombrich, E. H. 2007 Arte e Ilusão, Martins Fontes.

* Gonçalves, M.A.S. 1994 Sentir, Pensar, Agir. Corporeidade e Educação, Campinas, Papirus.

* Greiner, C. 2005 O Corpo - Pistas para Estudos Indisciplinares, São Paulo, Annablume.

e Katz, H. 2001 Corpo e Processos de Comunicação, Revista Fronteiras estudos midiáticos Vol. 3 Nr. 2, Programa de PósGraduação em Comunicação da UNISINOS

Hall, S. 1997 A Identidade Cultural na Pós-Modernidade, Rio de Janeiro, DP\&A

1996 “Who needs Identity?” in Hall, S. \& du Gay, P. (eds) Questions of Cultural Identity, London, Sage

2003, Da Diáspora: Identidades e Mediações Culturais, Belo Horizonte UFMG 
1997 Representation, London, Sage

Heflinger Jr., J.E.; Levy, P.M.; Cantalice, R.S.C. 2005 Recordações de Infância de Carlota Schmidt no Ibicaba, Limeira, SP, Editora Unigráfica

1999 O Senador Vergueiro e a Imigração Européia, Sociedade Pró Memória de Limeira, Editora Unigráfica

Heidegger, M, 1986 The End of Philosophy and the Task of Thinking, em Taylor, M.C., in Deconstruction in Context, The University of Chicago Press

* Jung, C. G. 1964 O Homem e seus Símbolos, Editora Nova Fronteira, RS

lazzetta, F. 2004 Sons de Silício: Corpos e Máquinas Fazendo Música, Tese de doutorado em Comunicação e Semiótica, PUC-SP, disponível em http://www.nef.org.br/modules.php?name=Conteudo\&pa=showpage\&pid =S : acesso em agosto de 2004

Jung, C. G. 1964 O Homem e seus Símbolos, Editora Nova Fronteira, RS

* Kapoor, I. 2004 Hyper-self-reflexive development? Spivak on representig the Third World 'Other' in Third World Quarterly, vol. 25,no. 4, pp. 627-647

Klapproth, D.M. 2004 Narrative as Social Practice: Anglo-Western and Australian Aboriginal Oral Traditions, Mouton

Kress, G. 1997 Before Writing, Rethinking the paths to literacy, London, Routledge. 
Lacan, J. 1988 Ecrits: A Selection, London, Tavistock

Lakoff,G. ; Johnson,M. 1999 Philosophy in the Flesh, Basic Book, New York.

2002 Metáforas da Vida Cotidiana, Mercado de Letras e EDUC, São Paulo.

Langer, S. K. 1971 Filosofia em Nova Chave, SP, Perspectiva.

Laraia, R. de Barros, 2001 Cultura, Jorge Zahar Editor, Rio de Janeiro

- Lave, J. 1997 The Culture of Acquisition and Practice of Understanding em Situated Cognition, Kirshner, D. \& Whiston, J. A. (eds.) London, Lawrence Erlbaum Associates.

* Lechte, J. 1994 Fifty Key Contemporary Thinkers , Routledge, London

* Leff, H. 2003 Pensar a Complexidade Ambiental em Leff, H.(coord.),A Complexidade Ambiental, São Paulo, Cortez

Lemke, J. L. 1997 Cognition, Context, and Learning: A Social Semiotic Perspective em Situated Cognition, Kirshner, D. \& Whiston, J. A. (eds.) London, Lawrence Erlbaum Associates.

* Levy, P.M. 1997 Família Levy: 140 anos de Brasil, Limeira

Martins, C. 2002 Improvisação, Dança, Cognição, tese de doutorado (PUC-SP)

Menezes de Souza, L.M.T. 2004 "Hibridismo e Tradução Cultural em Bhabha", in Abdala Junior, B. Margens da Cultura: Mestiçagem, 
2006 'Sistematizando a Obra' monografia de livre docência não publicada, $1^{\text {a }}$ parte.

* Merleau-Ponty, M. 1945 Fenomenologia da Percepção, São Paulo, Livraria Freitas Bastos S. A. 1971.

1961 Merleau-Ponty na Sorbonne, Campinas, Papirus.

1984 O Visível e o Invisível, São Paulo,

Perspectiva.

* Milton, J. 1993 "Cabala, Babel e Bíblia" em Tradução: Teoria e Prática, Martins Fontes, São Paulo 1998

* Monte Mór, W., 1999, Linguagem e Leitura da Realidade: Outros Olhos e Outras Vozes, Tese de Doutorado, USP, não publicada 2000, “Visíveis Cenas Invisíveis: 0 Desenvolvimento do Olhar", Claritas, Revista do departamento de Inglês, PUC-SP, N06:65-79, maio/2000, São Paulo, EDUC 1991, O Aspecto Ideologizante do Ensino de Língua Inglesa No Brasil, dissertação de mestrado

Morin, E., 2000, A Cabeça Bem Feita, RJ, Ed. Bertrand Brasil

Nee, W. 1987 A Liberação do Espírito, São José dos Campos, CLC Editora. 1989 O Homem Espiritual, Belo Horizonte, Edições Parousia

* Nunan, D. 1988 The Learner-Centered Curriculum, Cambridge University Press, Cambridge

Ots, T. 1994 "The silenced body - the expressive Leib: on the dialectic of mind and life in Chinese cathartic healing" em Csordas, T.J. (ed.) Embodiment and Experience: the existential ground of culture and self, Cambridge University Press. 
* Perrenoud, P. 199910 Novas Competências para Ensinar, Artmed, Porto Alegre 2000

* Rajagopalan, K., 1992, "O Significado e sua Gênese: Algumas Anotações Avulsas", in Arrojo, R.(Org.), O Signo Desconstruído, Campinas, Ed. Pontes

1992, "O Conceito de Interpretação na Lingüística:

Seus Alicerces e Seus Desafios", in Arrojo, R.(Org.), 0 Signo Desconstruído, Campinas, Ed. Pontes

* Rajchman, J. (org.) 1995 The Identity in Question, New York, Routledge

* Ricouer, P., 1977, Da Interpretação: Ensaio sobre Freud, RJ, Ed. Imago , 1978, Conflitos das Interpretações:Ensaios de Hermenêutica, RJ, Ed. Imago

* Romano, L. 2004 A construção de "Um Teto Só Seu": Cruzamento entre Processo Criativo, Teatro e Gênero, Projeto de Doutorado, USP-ECA

Rúbio, K. 2006 Medalhistas Olímpicos Brasileiros: Memórias, Histórias e Imaginário, São Paulo, Casa do Psicólogo, Fapesp, (Coleção Psicologia do Esporte)

* Saussure, F. de 1974 Course in General Linguistics, London, Peter Owen

* Sayad, A. 1998 A Imigração, Edusp

* Soja, E. W. 1996 Thirdspace, Blackwell Publishing.

Steiner, G. 1975 After Babel, Oxford University Press. 
* Taylor, C. 1985 "The person" in The Category of the Person, edited by Carrithers, Collins and Lukes, Cambridge University Press

* Turner, T. 1994 "Bodies and anti-bodies: flesh and fetish in contemporary social theory" em Csordas, T.J. (ed.) Embodiment and Experience: the existential ground of culture and self, Cambridge University Press.

Usher, R. ; Edwards, R. 1994 Postmodernism and Education, New York, Routledge.

Van Lier, L. 1989 "Ethnography: Bandaid, Bandwagon, or Contraband?" em Research in the Language Classroom, Brumfit and Mitchell (eds), Macmillan Education Ltd.

Varela, F.J.; Thompson, E.T.; Rosch, E. 1992 , The Embodied Mind, MIT Press

Vieira, A. G. Do Conceito de Estrutura narrativa à sua Critica , disponível em: http://www.scielo.br/scielo.php?script=sci arttex\&pid=S0102-79722001000300015\&lng=en\&nrm=iso : acesso em outubro 2005

Vygotsky, L. S. 1993 Pensamento e Linguagem, São Paulo, Martins Fontes.

Wilde, O. 1998 Plays, Prose Writings and Poems, Everyman, London

Witter, J. S. 1982 Ibicaba, uma experiência pioneira, coleção monografias 5, Edições Arquivo do Estado, SP. 1986 A Revolta dos Parceiros, São Paulo, Brasiliense. 


\section{FONTES DE FOTOS:}

Heflinger Jr., J.E.; Levy, P.M.; Cantalice, R.S.C. 2005 Recordações de Infância de Carlota Schmidt no Ibicaba, Limeira, SP, Editora Unigráfica

Heflinger Jr., J.E. 2007 Ibicaba o Berço da Imigração de Cunho Particular, Limeira, SP, Editora Unigráfica

Heflinger Jr., J.E. ; Heflinger Jr. M.H.L. ; Revista Povo, Novembro 2007, Limeira, CR Gráfica e Editora Ltda. 
Performance: "The Book Is On The Table"

Gostaria de deixar registrado que, para dar início à defesa desta dissertação de mestrado, no dia 16 de Janeiro de 2008, fiz uma performance teatral que visava expor o complexo da linguagem para além da apenas falada ou escrita, mas como processo de ação, construção de significação e, também, expor as narrativas corporais que vivencio de corpo, alma e espírito e constroem minha identidade como pessoa e professora de inglês.

Envolta em uma teia de aranha que se estendia até a comissão julgadora e também alcançava o público, estávamos eu e minha mesa de estudo, sobre a qual repousavam livros das enciclopédias Conhecer e Barsa (Enciclopédia Britânica), minhas amigas de infância, o objeto de arte de Guto Lacaz - "The Book Is On The Table" devidamente invertido - e uma caixinha de surpresas na qual buscava os artifícios para "ver com clareza" aquilo que está invisível: óculos, lanterna e espelho.

Munida dos óculos, tentava dar andamento à leitura quando a dança do sono tomava conta do meu ser, repetidas vezes. Como alternativa de interesse, passei a ler a Bíblia: "Can you fathom the mysteries of God? Can you probe the limits of the Almighty?" (Job 11:7), a seguir munida da lanterna tento iluminar a significação dessas duas perguntas na Bíblia, no infinito, na banca e no público.

Especulações indefinidas à parte, passo a lidar com a vivência do meu dia-adia e peço a todos que repitam aquilo que teoricamente está definido: "The table is on the book", chocada e sem graça, desenvergo o objeto de arte e volto a reiterar o famoso paradigma "repeat please: the book is on the table" com voz distorcida e cansada. Disfarçadamente, procuro abrir o livro sobre a mesa e, novamente, choco-me e o fecho, busco no espelho de toucador a certeza de ver a imagem desejada para me transmitir alguma certeza de identidade. No entanto, choco-me mais ainda ao descobrir uma imagem de monstro no espelho, mostro o espelho a todos que passam a ser monstros, conforme Derrida (1978). 
Mostro, ainda, a todos, o grande segredo do livro que está em branco, expondo nossa indeterminação e nossa contingência. Disfarçadamente, guardo os objetos de "ver com clareza" o invisível, na caixa de surpresas, em uma tentativa de voltar à rotina, àquilo que me transmite "alguma segurança" de significação e que me garante "alguma identidade".

Foi uma experiência reveladora, pois a reação da banca não poderia ter sido mais significativa, Walkyria Monte Mor comentou a quebra do estilo do ritual acadêmico e classificou como muito interessante a busca da identidade da professora que percebe que o que diz e ensina pode não ter significado - "the table is on the book" "the book is on the table" -, e também percebe que o livro está vazio mas o espelho traz uma identidade já pronta. Discorreu sobre o cenário cuja teia de significados inclui a pesquisadora que quer significar além de uma modalidade (a da escrita), que está relacionado com a busca da pesquisadora presente no livro "Conhecer".

"A defesa ontem da Irene foi groundbreaking." "Você na sua apresentação corporal (mímica? Commedia dell'arte?) trouxe literalmente para o corpo (o teu) toda uma aprendizagem, uma pesquisa, uma vivência acadêmica, enfim uma VIDA em poucos minutos e literalmente em poucas palavras - coisa que muitos de nós lutamos uma vida inteira para fazer."

Lynn Mario Trindade Menezes de Souza. 